Técia Daltro Borges Alves

\title{
SAÚDE BUCAL DE ESCOLARES COM DOZE ANOS DE IDADE DO MUNICÍPIO DE FEIRA DE SANTANA /
}

BAHIA - zona urbana.

Tese apresentada à Faculdade de Saúde Pública da Universidade de São Paulo para obter o Título de Doutor em Saúde Pública.

Área de Concentração: Serviços de Saúde Pública

ORIENTADORA: Prof $^{\mathrm{a}} \mathrm{Dr}^{\mathrm{a}}$ Evelin Naked de Castro Sá

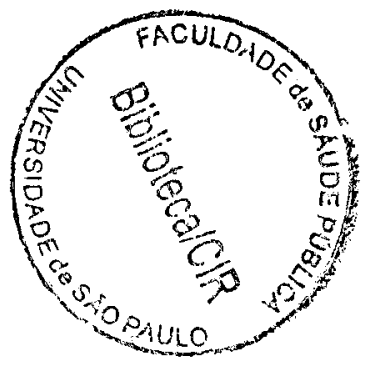


Técia Daltro Borges Alves

\section{SAÚDE BUCAL DE ESCOLARES COM DOZE ANOS

\author{
DE IDADE DO MUNICÍPIO DE FEIRA DE SANTANA /
}

BAHIA - zona urbana.

Tese apresentada à

Faculdade de Saúde Pública

da Universidade de São

Paulo para obter o Título de Doutor em Saúde Pública.

Área de Concentração:

Serviços de Saúde Pública

ORIENTADORA:

Prof $^{a}$ Dr $^{a}$ Evelin Naked de Castro Sá 
Autorizo, exclusivamente para fins acadêmicos e cientificos, a reprodução total ou parcial desta tese, por processos fotocopiadores.

Assinatura: SiéciaDifle s

Data: $27 / 05103$

$$
43786 / 2003 \text { doc }
$$


Sábado à tarde, 16:0oh, céu limpo e ensolarado, eu estava ao computador em contínuos dias de jornada intermináveis. Emily faz uma pergunta: - "Minha mãe, este trabalho seu não acaba nunca?" Enfim, eis o trabalho concluído!

Assim, dedico esta tese:

às minhas filhas Lísia ( 8 anos) $\mathrm{e}$ Emily (4 anos), que tanto sofreram com as minhas ausências (mesmo estando presente) durante esta etapa de minha vida,

aos escolares, objetivo maior desta pesquisa, na esperança de que a mesma possa trazer benefícios à sua saúde bucal. 


\section{AGRADECIMENTOS ESPECIAIS}

"Sonhos são como Deuses, quando não

se acredita neles deixam de existir", portanto agradeço a Deus pela

concretização deste sonho.

A Marcos, meu marido, pelo empenho e solicitude em me ajudar nos momentos difíceis desta jornada.

A meus pais, Erisvaldo e Maria José. pelo constante apoio incondicional, especialmente a minha mãe que me auxiliou neste curso, assumindo minhas filhas na minha ausência, resolvendo meus problemas e até mesmo participando da pesquisa como anotadora assídua e interessada.

A Pof $^{\mathrm{a}}$ Dr ${ }^{\mathrm{a}}$ Evelin Naked de Castro Sá, que soube ser muito mais do que uma orientadora, sabendo ser exigente quando a função exigia, mas também terna $\mathrm{e}$ compreensiva, me defendendo e apoiando como se faz com uma filha.

À Família Pavan, Oscar, Eliana, Eduardo e Diego, que me acolheram em seu lar de forma gentil sempre que estive em São Paulo, suavizando as angústias que a distância me trazia. ao me "adotarem" tão carinhosamente.

Ao casal André e Suzi Barboni, amigos conquistados neste curso e que apesar de também atribulados com as suas teses, não mediram esforços para me ajudar, seja na construção do trabalho, seja para compartilhar os sofrimentos $\mathrm{e}$ apreensões inerentes ao processo. 


\section{AGRADECIMENTOS}

Aos escolares voluntários que concordaram em fazer parte da pesquisa e a seus pais pela colaboração e pela permissão para o exame de seus filhos. Muito obrigada pela confiança depositada!

À Prof $^{\mathrm{a}}$ Dr $^{\mathrm{a}}$ Anaci Bispo Paim, por ter acreditado no projeto de cooperação interinstitucional USP/UEFS, concretizando o convênio em sua gestão na Reitoria e por suas palavras e ações de estímulo à minha vida acadêmica.

À Célia Maria Bispo, minha secretária do consultório, pela colaboração durante a coleta de dados e por organizar a minha agenda com sua denotada paciência em administrar as minhas atividades pessoais, do curso de Doutorado, do consultório e da Universidade.

Aos colegas da área de Odontologia Social da UEFS, que me incentivaram a fazer este curso, "segurando as pontas nas minhas atividades docentes" e colaboraram com a elaboração do trabalho. Em especial, aos Profs. Valéria Souza Freitas, Joildo Guimarães Santos, Nilton César Nogueira Santos, Maria Bernadete Bené Cavalcante Barbosa, Augusto César C. Cardoso, Ana Luíza Sarno Castro e Ulisses Anselmo.

À Tânia Lago, da Coordenação do Curso de Doutorado em Saúde Pública na UEFS, pela constante e sempre alegre disponibilidade em nos auxiliar durante o curso.

Ao Prof. Carlos Teles, pela valiosa contribuição em toda a construção e análise estatística da Tese.

Aos Profs. Drs. Paulo Capel Narvai, Roberto Augusto Castellanos e Paulo Frazão, por suas experientes orientações no desenvolvimento do trabalho.

Ao corpo docente do Curso de Doutorado pelas lições transmitidas. Em particular à Prof ${ }^{\mathrm{a}}$ Sabina Léa Davidson Gotlieb que sabe nos orientar sobre que está errado com uma elegância tal, que torna impossível não acertar depois. 
Aos Profs. Drs. Milton Fernando de Andrade Silva e Isaac Suzart Gomes Filho, por estarem ao meu lado em várias conquistas da minha vida e pelo exemplo de dedicação à vida acadêmica e à ciência.

Aos colegas do Curso, pelas emoções, dificuldades e aprendizado compartilhados.

Às Escolas e suas administrações, pela receptividade calorosa e por não pouparem esforços em me ajudar.

Ao Prof. Josias Paulo dos Santos e seus estagiários, do Laboratório de Geoplanejamento(GEOPLAN) - UEFS, pela prestimosa cooperação e empenho na localização das escolas no mapa do município de Feira de Santana.

À Divisão Odontológica da Secretaria Municipal de Saúde de Feira de Santana, em particular ao Dr. Helton Dourado Casaes, por sua disponibilidade em me receber e buscar as informações relativas às ações em saúde bucal no município.

À Diretoria Estadual de Educação(DIREC-2), em particular à Diretora Prof ${ }^{\text {a }}$ Lindinalva Cedraz, pelo fornecimento das informações sobre o cadastro das escolas e escolares de doze anos no município.

À bibliotecária Maria Lúcia Ferraz, da Biblioteca da Faculdade de Saúde Pública, por seu esforço em conseguir as referências bibliográficas para o trabalho.

A todos aqueles que de alguma maneira contribuíram para a realização e finalização deste curso. 


\section{RESUMO}

Alves TDB. Saúde bucal de escolares com doze anos de idade do município de Feira de Santana /Bahia - zona urbana. São Paulo; 2003. [Tese de Doutorado - Faculdade de Saúde Pública da Universidade de São Paulo].

Objetivo. O estudo objetivou analisar a saúde bucal de escolares com doze anos de idade na área urbana do município de Feira de Santana - BA. Métodos. Após exames bucais em escolares com doze anos de idade das escolas estaduais $(n=318)$, municipais $(n=334)$ e particulares $(n=319)$ estimouse a prevalência da cárie dentária, doença periodontal, oclusopatias e fluorose dentária segundo os índices da Organização Mundial de Saúde (1997). Na análise, investigou-se as diferenças segundo o tipo de escola, sexo e etnia $(\alpha=0,05)$. Resultados. $O$ índice CPOD médio dos escolares (Estaduais: 1,89, Municipais: 2,17 e Particulares: 2,39) não apresentou diferenças estatísticas entre as escolas. No CPOD ocorreu uma maior participação do componente cariado nas escolas públicas e obturado nas particulares $\left(X^{2}=535,52 ; p=0,000\right)$. Condições periodontais mais favoráveis e significativas ocorreram nas escolas particulares $\left(X^{2}=105,16 ; p\right.$ $=0,000$ ). A prevalência de oclusopatias (Estaduais: $55,2 \%$, Municipais: 47,7\% e Particulares: $48,0 \%$ ) não apresentou diferença estatística entre as escolas. A prevalência de fluorose dentária (Estaduais: 45,6\%, Municipais: $36,5 \%$ e Particulares: $34,0 \%)$ mostrou diferenças entre as escolas $\left(X^{2}=\right.$ $46,89 ; p=0,000)$. Sobre o sexo e etnia, registrou-se diferenças significativas somente nas escolas municipais nas condiçōes periodontais e oclusopatias, respectivamente. Conclusão. De acordo com o tipo de escola, os escolares de doze anos, possuem baixas prevalências de cárie e doença periodontal e altas prevalências de fluorose dentária e oclusopatias. O quadro de saúde bucal apresentado evidenciou a necessidade de novos estudos e da formulação de políticas de atenção ao escolar no município.

Descritores: saúde bucal, escolares, levantamento epidemiológico. 


\section{SUMMARY}

Alves TDB. Saúde bucal de escolares com doze anos de idade do município de Feira de Santana /Bahia - zona urbana. [Twelve years-old children oral health of Feira de Santana/Bahia - urban area.] São Paulo (BR); 2003. [Tese de Doutorado - Faculdade de Saúde Pública da Universidade de São Paulo].

Objective. The purpose of the study was analyse the oral health of the twelve years old schoolchildren on urban área in the Feira de Santana-BA city, Brazil. Methods. After oral examinations in twelve years old schoolchildren of state schools $(n=318)$, municipal $(n=334)$ and private $(n=319)$ it as estimated the prevalence of dental caries, periodontal disease, malocclusion and dental fluorosis according to the World Health Organization(1997) indexes. In the analysis, the differences among school type, sex and ethnic were investigated $(\alpha=0.05)$. Results. The mean DMFT of the schoolchildren (State: 1.89, Municipal: 2.17 and Private: 2.39) were not statistically significant between schools. In DMFT, it was observed a higher participation of the decayed component in public schools and the filled in private $\left(X^{2}=535.52 ; p=0.000\right)$. Periodontal conditions most favorable and significant occurred on private schools $\left(X^{2}=105.16 ; p=0.000\right)$. The malocclusion prevalence (State: $55.2 \%$, Municipal: $47.7 \%$ and Private: $48.0 \%$ ) showed no statistical difference among schools. The dental fluorosis prevalence (State: $45.6 \%$, Municipal: $36.5 \%$ and Private: $34.0 \%$ ) showed differences between schools $\left(X^{2}=46.89 ; p=0.000\right)$. In relation to sex and ethnic, were registered statistical differences only in municipal schools on the periodontal conditions and malocclusion, respectively. Conclusion. According to the school type, the twelve years old schoolchildren, have low caries and periodontal disease prevalences and high dental fluorosis and malocclusion prevalences. The showed oral health status evidenced the need of new studies and formulation of care policies in the city.

Descriptors: oral health, schoolchildren, survey. 


\section{LISTA DE QUADROS E TABELAS}

Tabela 1 - Distribuição do número de escolas e número de matrículas por dependência administrativa. Feira de Santana - BA, 2000 ...

Tabela 2 - Distribuição do número de escolas do ensino fundamental, número de escolas com alunos de doze anos e de escolares com doze anos de idade segundo dependência administrativa e localização da escola. Feira de Santana - BA, 2000

Tabela 3 - Distribuição do número de escolares do ensino fundamental segundo sexo, dependência administrativa e localização da escola. Feira de Santana - BA, 2000.

Quadro 1 - Distribuição dos valores DAl padrão.

Tabela 4 - Distribuição do número e percentual dos escolares de doze anos examinados segundo sexo e tipo de escola. Feira de Santana - BA, zona urbana, 2002

Tabela 5 - Distribuição do número e percentual dos escolares de doze anos examinados segundo etnia e tipo de escola. Feira de Santana - BA, zona urbana, 2002

Tabela 6 - Índices de Kappa, intra-examinador, calculados na calibração inicial e nos reexames para as condições examinadas em escolares de doze anos de idade. Feira de Santana - BA, zona urbana, 2002

Tabela 7 - Distribuição do número e percentual dos escolares de doze anos examinados segundo valores do indice CPOD e tipo de escola. Feira de Santana - BA, zona urbana, 2002

Tabela 8 - Distribuição do número e percentual de dentes permanentes de escolares de doze anos de idade, segundo componentes do índice CPOD e tipo de escola. Feira de Santana - BA, zona urbana, 2002

Tabela 9 - Média dos componentes e do índice CPOD segundo tipo de escola, desvio padrão e intervalos de confiança de $95 \%$. Feira de Santana - BA, zona urbana, 2002

Tabela 10 - Distribuição do número e percentual dos escolares de doze anos segundo valores do índice CPOD, sexo e tipo de escola. Feira de Santana - BA, zona urbana, 2002

Tabela 11 - Distribuição do número e percentual dos escolares de doze anos examinados segundo valores do índice CPOD, etnia e tipo de escola. Feira de Santana - BA, zona urbana, 2002 
Tabela 12 - Distribuição do número e percentual de dentes segundo necessidades de tratamento e tipo de escola em escolares de doze anos de idade. Feira de Santana - BA, zona urbana, 2002

Tabela 13- Distribuição do número e percentual de dentes segundo tipo de necessidade de tratamento e escola, em escolares de doze anos de idade. Feira de Santana - BA, zona urbana, 2002

Tabela 14 - Distribuição do número e percentual de escolares de doze anos segundo a pior condição periodontal encontrada por indivíduo e tipo de escola. Feira de Santana - BA, zona urbana, 2002

Tabela 15 - Distribuição do número e percentual de escolares de doze anos de idade segundo condições periodontais, sexo e tipo de escola. Feira de Santana - BA, zona urbana, 2002

Tabela 16 - Distribuição do número e percentual de escolares de doze anos de idade segundo condições periodontais, etnia e tipo de escola. Feira de Santana - BA, zona urbana, 2002.

Tabela 17 - Distribuição do número e percentual de sextantes examinados em escolares de doze anos de idade segundo condição periodontal e tipo de escola. Feira de Santana - BA, zona urbana, 2002

Tabela 18 - Distribuição percentual de sextantes examinados segundo condição periodontal e sextantes superiores e inferiores. Feira de Santana - BA, zona urbana, 2002

Tabela 19 - Distribuição do número e média de sextantes examinados em escolares de doze anos de idade segundo condição periodontal e tipo de escola. Feira de Santana - BA, zona urbana, 2002

Tabela 20 - Distribuição do número e percentual de escolares de doze anos de idade segundo o número de sextantes sadios por indivíduo e tipo de escola. Feira de Santana - BA, zona urbana, 2002

Tabela 21 - Distribuição do número e percentual dos escolares de doze anos examinados para o cálculo do DAl segundo sexo e tipo de escola. Feira de Santana - BA, zona urbana, 2002

Tabela 22 - Distribuição do número e percentual dos escolares de doze anos examinados para o cálculo do DAl segundo etnia e tipo de escola. Feira de Santana - BA, zona urbana, 2002.

Tabela 23 - Distribuição do número e percentual de escolares de doze anos de idade segundo o grau de oclusopatia 
(DAI) e o tipo de escola. Feira de Santana - BA, zona urbana, 2002.

Tabela 24 - Distribuição do número e percentual de escolares de doze anos de idade segundo o grupo de condição dentição e o tipo de escola. Feira de Santana - BA, zona urbana, 2002

Tabela 25 - Distribuição do número e percentual de escolares de doze anos de idade segundo o grupo de condição espaço e o tipo de escola. Feira de Santana - BA, zona urbana, 2002

Tabela 26 - Distribuição do número e percentual de escolares de doze anos de idade segundo o grupo de condição oclusão e o tipo de escola. Feira de Santana - BA, zona urbana, 2002

Tabela 27 - Distribuição do número e percentual de escolares de doze anos de idade segundo relação molar anteroposterior e tipo de escola. Feira de Santana-BA, zona urbana, 2002

Tabela 28 - Distribuição do número e percentual de escolares de doze anos de idade segundo o grau de oclusopatia (DAI), sexo e o tipo de escola. Feira de Santana - BA, zona urbana, 2002

Tabela 29 - Distribuição do número e percentual de escolares de doze anos de idade segundo o grau de oclusopatia (DAI), etnia e o tipo de escola. Feira de Santana - BA, zona urbana, 2002

Tabela 30 - Distribuição do número e percentual de escolares de doze anos de idade segundo o grau de fluorose dentária e tipo de escola. Feira de Santana - BA, zona urbana, 2002.

Tabela 31 - Distribuição do número e percentual de escolares de doze anos de idade segundo o grau de fluorose dentária, sexo e tipo de escola. Feira de Santana - BA, zona urbana, 2002

Tabela 32 - Distribuição do número e percentual de escolares de doze anos de idade segundo o grau de fluorose dentária, etnia e tipo de escola. Feira de Santana - BA, zona urbana, 2002.

Tabela 33 - Distribuição do número e percentual de pais de escolares de doze anos de idade segundo o tipo de ocupação e de escola. Feira de Santana - BA, zona urbana, 2002

Tabela 34 - Distribuição do número e percentual de pais de escolares de doze anos de idade segundo o nível de 
escolaridade e tipo de escola. Feira de Santana - BA, zona urbana, 2002

Tabela 35 - Distribuição do número e percentual de pais de escolares de doze anos de idade segundo a renda familiar em salários mínimos (S.M.) e tipo de escola. Feira de Santana - BA, zona urbana, 2002.

Tabela 36 - Distribuição do número e percentual de pais de escolares de doze anos de idade segundo a qualificação da saúde bucal de seus filhos e tipo de escola. Feira de Santana - BA, zona urbana, 2002 


\section{LISTA DE FIGURAS}

Figura 1 - Tamanho das amostras, número de exames realizados e percentuais de perdas em cada grupo de escolas.

Feira de Santana - BA, 2002

Figura 2 - Distribuição geográfica das escolas incluídas na pesquisa, segundo tipo, no Município de Feira de Santana-BA, 2002.

Figura 3 - Distribuição percentual de escolares aos doze anos segundo os valores do CPOD e tipo de escola, Feira de Santana - BA, zona urbana, 2002

Figura 4 - Número médio de dentes cariados, perdidos e obturados em escolares aos doze anos de idade, segundo componentes e tipo de escola. Feira de Santana - BA, zona urbana, 2002

Figura 5 - Distribuição percentual dos graus de oclusopatia em escolares de doze anos de idade segundo os valores de $C P O D \leq 3$ e $C P O D \geq 4$. Feira de Santana - BA, zona urbana, 2002.

Figura 6 - Distribuição percentual dos graus de fluorose dentária em escolares de doze anos de idade segundo tipo de escola. Feira de Santana - BA, zona urbana, 2002. 


\section{ÍNDICE}

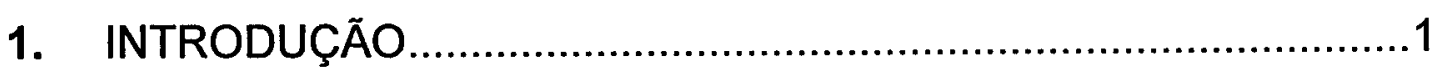

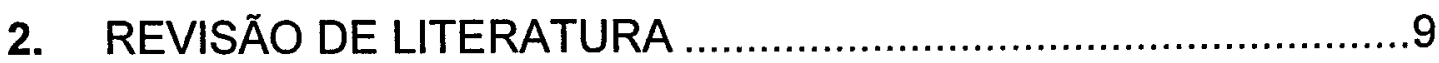

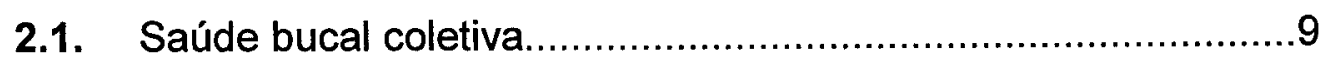

2.2. Os problemas da saúde bucal coletiva .................................13

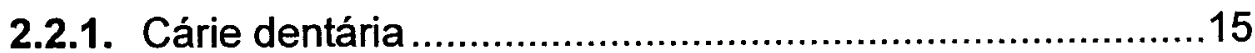

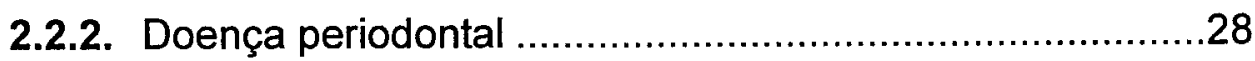

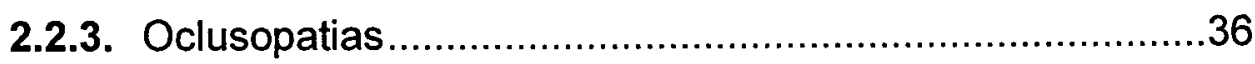

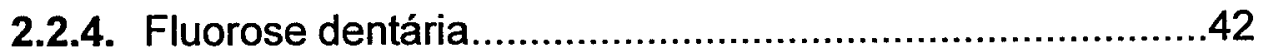

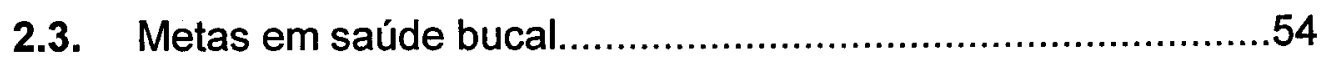

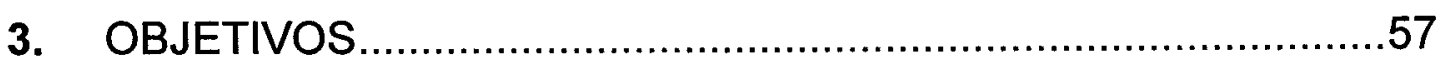

4. MATERIAL E MÉTODOS …..................................................58

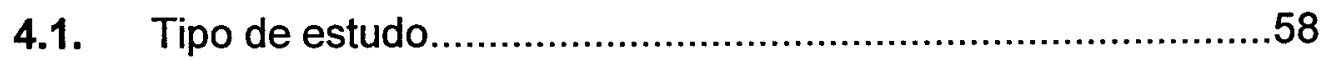

4.2. População de referência......................................................58

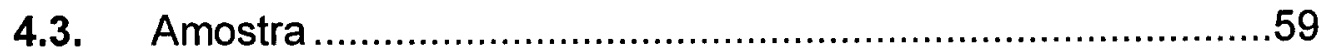

4.3.1. Critérios para a composição da amostra .........................59

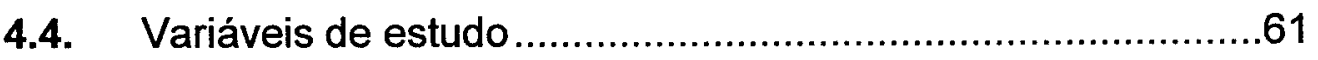

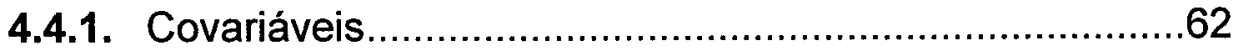

4.5. Critérios para a produção dos dados....................................62

4.5.1 Condições fisicas, instrumental e examinador .................62

4.5.2 Índice CPOD e necessidades de tratamento..................63

4.5.3 Índice periodontal comunitário $(\mathrm{CPI})$............................68

4.5.4 Índice estético dentário (DAl) ........................................

4.5.5 Índice de fluorose dentária .........................................74

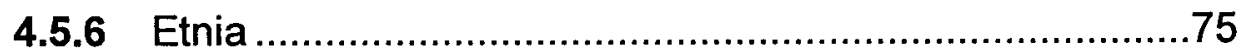

4.5.7 Escolaridade, renda familiar, acesso ao atendimento odontológico, hábitos de higiene bucal e dieta.................76

4.6. Análise estatística................................................................

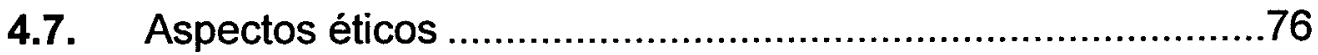

4.8. Dificuldades na realização da pesquisa ................................77 


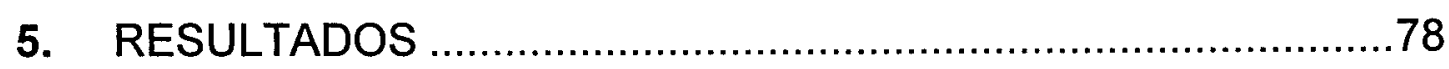

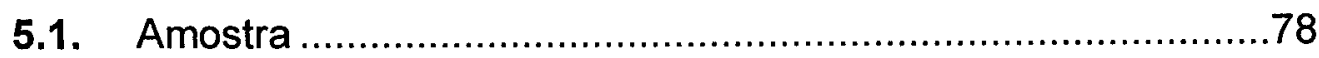

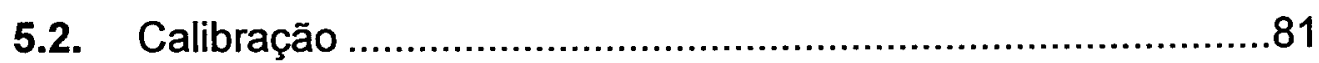

5.3. Cárie dentária e necessidades de tratamento ........................82

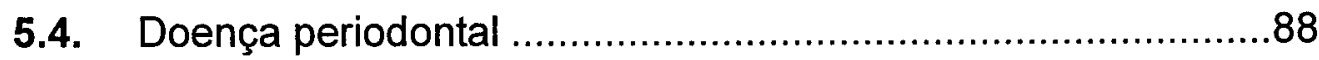

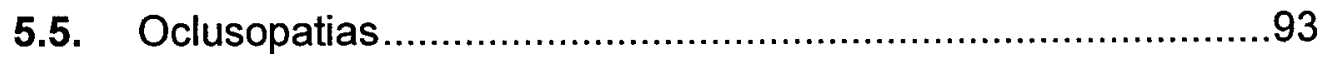

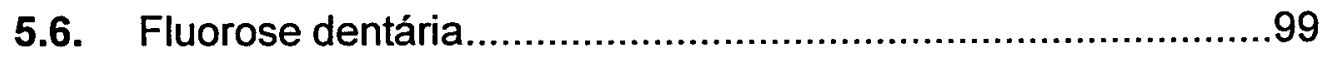

5.7. Açōes em Saúde Bucal aos escolares ................................102

5.8. Formulários dos pais .....................................................103

5.9. Formulários das crianças..................................................107

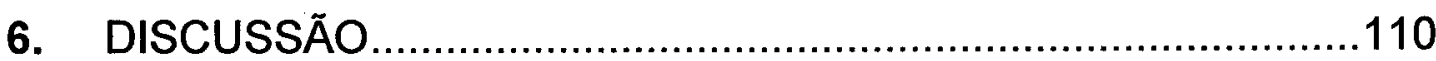

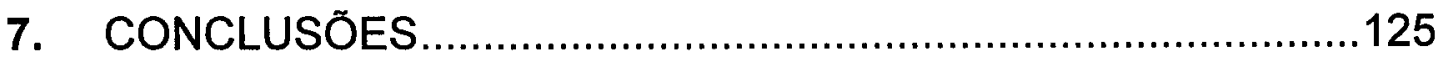

8. REFERÊNCIAS BIBLIOGRÁFICAS ....................................128 ANEXOS

ANEXO 1 - Tamanho da amostra para o caso de uma média com precisão de $10 \%$ e confiança de $95 \%$..................... A2

ANEXO 2 - Formulário para os pais................................................A3

ANEXO 3 - Formulário para as crianças .......................................... A4

ANEXO 4 - Ficha para o exame clínico adaptada da ficha proposta pela WHO (1997)........................................... A5

ANEXO 5 - Carta à diretoria das escolas ........................................

ANEXO 6 - Solicitação de autorização ao pai ou responsável..........A7

ANEXO 7 - Parecer no 036/01 do Comitê de Ética da FSPUSP sobre o trabalho .................................................. A8

ANEXO 8 - Quadros com os cálculos do índice de Kappa na calibração inicial e nos reexames. 


\section{INTRODUÇÃO}

A motivação para pesquisar a saúde bucal dos escolares com doze anos de idade do município de Feira de Santana/Bahia - zona urbana surgiu da inquietude em registrar dados de saúde bucal sobre esse grupo populacional e da necessidade de conduzir um trabalho que permitisse continuar seguindo as temáticas das demais teses do curso de Doutorado em Saúde Pública, realizado em convênio de cooperação técnica entre a Universidade Estadual de Feira de Santana - UEFS e a Universidade de São Paulo - USPI Faculdade de Saúde Pública. Os trabalhos desse doutorado investigaram diferentes temáticas, tais como qualidade de vida e políticas públicas, motivos de escolha da esterilização em mulheres, qualidade de vida em pacientes renais crônicos, ocorrência de Vibrio spp potencialmente patogênicos em moluscos bivalves da região da Baía de Todos os Santos e Valença - Bahia, entre outras, com a finalidade de contribuir para a melhoria da saúde da população, o desenvolvimento da pesquisa e o ensino universitário no município ou região, cumprindo também com os objetivos propostos no termo de convênio entre as instituições envolvidas (USP/UEFS 1999).

A cidade de Feira de Santana surgiu no Século XVIII, por volta do ano de 1732. Foi originada da Fazenda Santana dos Olhos D'Água de propriedade do casal de portugueses Domingos Barbosa de Araújo e Ana Brandoa. Esta fazenda pertencia à Paróquia de São José das Itapororocas e por ela passava uma estrada de boiadas por onde viajavam vaqueiros, tropeiros e outros viajantes que conduziam o gado vindo do sertão para ser vendido nas cidades de Cachoeira, Santo Amaro e Salvador. Formou-se no local uma feira de gado onde também era efetuada a comercialização de outras mercadorias, dando origem ao povoado Santana da Feira (PINTO JAL 2000). O povoado cresceu e tornou-se vila em 1833. Em 16 de junho de 1873, emancipou-se do município de Cachoeira, passando a ser conhecida como Cidade Comercial de Feira de Santana (MAXADO 2000). 
$\mathrm{O}$ município possui uma área de $1.334 \mathrm{Km}^{2}$, está situado na Região Centro Norte Baiano e com outros municipios forma a microrregião de Feira de Santana. É cortado por várias rodovias federais importantes tais como BR 101,116 e 324 , além de quatro rodovias estaduais, figurando como um dos maiores entroncamentos rodoviários do país. Suas terras estendem-se pelo tabuleiro do leste baiano, na fronteira do recôncavo semi-árido, sendo que $96 \%$ de seu território faz parte do "Polígono das Secas". O clima é subtropical quente e úmido com temperatura média anual de $27^{\circ} \mathrm{C}$ e a umidade relativa do ar de até $80 \%$ em alguns meses do ano.

A cidade de Feira de Santana é a segunda mais populosa do Estado da Bahia, apresentando, no Censo do ano 2000, uma população de 480.949 habitantes, sendo que seu maior percentual está situado na zona urbana $(89,76 \%)$, enquanto que apenas $10,24 \%$ se encontram na zona rural. $A$ distribuição populacional por sexo é relativamente equilibrada, com ligeira predominância do sexo feminino. Apresenta uma taxa de alfabetização de $86,9 \%$, taxa de densidade demográfica de 360,96 hab $/ \mathrm{Km}^{2}$ e taxa de crescimento anual estimada entre 1996 a 2000 de 2,1\%, podendo ocorrer variações rápidas associadas ao fenômeno migratório (IBGE 2000).

O Setor Educacional conta com estabelecimentos de ensino, compostos por escolas públicas estaduais e municipais e da rede particular, uma Universidade Estadual (UEFS) e cinco Faculdades particulares.

O município tem sua base econômica no comércio, pecuária e indústria. A área industrial foi a que mais se desenvolveu nos últimos anos através do Centro Industrial Subaé.

Possui uma rede de abastecimento de água tratada que cobre cerca de 103.750 domicilios, enquanto que o serviço de esgotamento sanitário atinge apenas 39\% dos domicilios (IBGE 2000). As condições geológicas propiciam o afloramento de diversas nascentes e a presença de lagoas devido a superficialidade do lençol freático, o que facilita a utilização de poços artesianos nos domicilios, bem como a contaminação deste lençol por esgotos domésticos. 
A fluoretação da água de abastecimento público, no município, ocorreu de meados de 1976 até 1987. Após 10 anos de paralisação e mediante incessantes discussões em diversos setores da classe odontológica, em 1997, obteve-se da Empresa Baiana de Águas e Saneamento S/A (EMBASA) a reativação deste serviço. No entanto, desde a reimplantação da medida, não é desenvolvido um controle de vigilância sanitária dos teores de flúor utilizados (SILVA CAL, ALVES e FREITAS 1998). Ressalta-se também que medidas preventivas como esta diminuem em eficácia se interrompidas e descontinuadas.

O município de Feira de Santana apresenta, em relação ao seu quadro epidemiológico, uma superposição de problemas e agravos à saúde, tendo o seu perfil composto tanto por doenças crônico-degenerativas, cânceres e doenças cardiovasculares; por causas externas, acidentes automobilisticos e violência em geral, relacionadas ao modo e estilo de vida urbana; quanto por doenças ligadas à pobreza e às péssimas condições de vida as quais ainda está exposta grande parte da população (PMFS/SMS 2002a).

As informações sobre óbitos revelam que no periodo entre 1996 a 2000 as doenças do aparelho circulatório apareceram em primeiro lugar em todos os anos da série histórica $(35,1 \%)$, seguida das causas externas $(15,8 \%)$, neoplasias $(11,5 \%)$ e outras $(37,6 \%)$. Os óbitos por doenças do aparelho respiratório aparecem como quarta causa de óbitos nos primeiros quatro anos da série, sendo que em 1999 e 2000 houve substituição pelas causas ligadas a doenças endócrinas, nutricionais e metabólicas (PMFS/SMS 2002a).

Os problemas de saúde referidos pela população em relação às prioridades são: hipertensão/diabetes, verminoses/escabiose/dermatose, diarréia/desnutrição/infecções respiratórias, cárie dentária, gravidez na adolescência, doença mental/alcoolismo/drogas e neoplasias. Quanto a problemas organizacionais é referido pela população em $10^{\circ}$ lugar a ausência de Programa de Saúde Bucal em algumas Unidades Básicas de Saúde - UBS (PMFS/SMS 2002a). 
O município se encontra na Gestão Plena da Atenção Básica pleiteando assumir a condição Plena do Sistema Municipal. A rede básica municipal é composta por trinta e cinco Unidades Básicas com dezesseis equipes do Programa de Saúde da Família (PSF) na sede e dezoito UBS nos distritos com cinco equipes do PSF.

Quanto à média complexidade para apoio diagnóstico e terapêutico, são utilizados os prestadores conveniados ao SUS e encaminhamentos para Salvador, capital do Estado. Os procedimentos de alta complexidade são realizados em sua maioria pela rede privada contratada.

A rede hospitalar pública é composta de dois hospitais estaduais, um especializado em psiquiatria e outro geral de referência para a região, e um hospital municipal especializado em atenção à mulher. Além disso, existem no município: um hospital filantrópico, três hospitais privados e uma maternidade conveniada ao SUS.

Apesar da extensa rede de serviços básicos, existente no município, a cobertura de atendimento à população em relação a consultas e outros serviços básicos ainda é deficitária, merecendo um reordenamento das ações, uma vez que a organização dos serviços tem ênfase na demanda espontânea (PMFS/SMS 2002a).

Em relação à Odontologia, existem trezentos e dezoito cirurgiõesdentistas inscritos na Delegacia Regional de Feira de Santana do Conselho Regional de Odontologia da Bahia, atuando no município e microrregião, no serviço privado e público. Neste último, coordenadas pela Secretaria Municipal de Saúde - Divisão Odontológica, são desenvolvidas atividades em dezesseis UBS na sede e oito nos distritos. Nessas UBS são realizados os seguintes procedimentos: restauração, extração, profilaxia e tartarectomia. A equipe é composta por sessenta e cinco cirurgiōesdentistas, sendo quarenta e seis da Secretaria Municipal de Saúde, quinze da Secretaria Estadual e os demais da União e da Secretaria de Educação à disposição do municipio ou ainda em duplo vínculo. Em nivel médio não existem no quadro de recursos humanos as categorias de Atendente de 
Consultório Dentário (ACD) e Técnico de Higiene Dental (THD). Bem como não existem equipes de Saúde Bucal no PSF.

São desenvolvidas também atividades coletivas de Saúde Bucal junto ao Programa de Atenção Integral à Saúde da Criança - PAISC , uma vez por semana, onde uma Unidade Móvel Odontológica é encaminhada a uma comunidade que não possua atendimento odontológico e retorna uma vez por mês a esta mesma comunidade.

Com respeito aos escolares, foi implantado em 2000, pela Portaria 014/00 SMS - Feira de Santana, um Programa de Saúde Bucal, denominado "Sorria Feira", destinado principalmente aos escolares das Escolas Municipais na faixa etária de seis a catorze anos. Esse programa teve como objetivos: executar levantamento epidemiológico nas escolas, realizar atividades de Educação em Saúde Bucal, supervisionar a dieta alimentar dos escolares e encaminhar as crianças aos Centros de Saúde do Bairro para atendimento. Ao todo, dez cirurgiões-dentistas compunham a equipe de trabalho do programa. As atividades eram desenvolvidas de forma pontual, onde em um dia previamente agendado na escola, eram realizadas palestras com alunos, pais, professores e funcionários e levantamento das necessidades acumuladas de saúde bucal, escovação orientada e aplicação tópica de flúor gel na escova dental em todas as crianças da escola. Ao final do Plano Municipal de Saúde 1998-2001 (PMFS/SMS 1997), após nove meses de implantação, o programa havia sido realizado em dezesseis escolas municipais, tendo atendido 4269 escolares. No relatório do final desta gestão a equipe de trabalho ressaltou a importância da continuidade das ações, sugerindo a implantação de bochechos fluoretados semanais ou quinzenais, bem como a necessidade de ajustes na merenda escolar e expansão do programa para toda a rede escolar municipal (PMFS/SMS 2000).

Destaca-se que, em 2000, a população residente no município com a idade de doze anos, era de 10.498 crianças sendo 5.196 do sexo feminino e 5.302 do sexo masculino. Destas, 9.217 residem na área urbana onde $92,83 \%$ são alfabetizados (MS/DATASUS 2000). 
Em 2001, com a mudança de gestão, o Programa sofreu algumas modificações especialmente no sentido de continuidade das ações. A equipe passou a ser composta por nove profissionais de Odontologia realizando as atividades descritas a seguir: escovação supervisionada, aplicação semestral de flúor, educação em saúde semanal por série englobando pais/ responsáveis e escolares, eventualmente evidenciação de placa, distribuição e troca das escovas dentais em média de quatro em quatro meses. Atualmente, cinqüenta e nove escolas municipais estão recebendo o programa, direcionado aos alunos das $1^{\mathrm{a}}$ e $2^{\mathrm{a}}$ séries do ensino fundamental. Até junho de 2002, 9466 crianças foram atendidas o que representa o percentual de $92 \%$ de escolares nestas séries nas escolas cadastradas no programa (PMFS/SMS 2002b).

Dentre as ações propostas pela Divisão de Odontologia da Secretaria Municipal de Saúde no Plano Municipal de Saúde de 2002, vale ressaltar aquelas destinadas aos escolares: assegurar higiene bucal supervisionada na população de zero a quatro anos, promover higiene bucal supervisionada com evidenciação de placa bacteriana e bochecho fluoretado na população de cinco a catorze anos.

É importante referir que apesar da mudança do enfoque do programa, de um modo geral as ações de odontologia no municipio não ocorrem de forma estruturada no sentido de integrar as atividades desenvolvidas nas UBS, escolas e outros espaços mediante um Programa de Saúde Bucal orientado segundo os dados epidemiológicos da população.

Neste cenário, ainda existem as atividades desenvolvidas pelo Curso de Odontologia da Universidade Estadual de Feira de Santana, que dispõe de seis clínicas, onde vários serviços que não são oferecidos à população pela rede básica municipal, em nivel de média e alta complexidade, são realizados gratuitamente (UEFS 2001). As ações desenvolvidas pelo curso de Odontologia da Universidade Estadual de Feira de Santana (UEFS), constam como um setor à parte, público assistencial, atuando em algumas escolas da cidade e promovendo atividades de educação em saúde e 
prevenção das doenças bucais, especialmente direcionadas pela área de Odontologia Preventiva e Social.

A articulação entre as ações de saúde desenvolvidas pela Secretaria Municipal de Saúde e pela UEFS ocorre em uma forma ainda incipiente e a existência de um programa de atuação com metas comuns para garantir melhores níveis de saúde bucal da população ainda não pode ser identificada.

Adicionalmente, não se dispõe de dados sobre os índices de saúde bucal da população do municipio, existindo apenas alguns trabalhos (CASTRO 1999; SANTOS et al. 1999) desenvolvidos por pesquisadores da UEFS. No entanto, esses trabalhos foram direcionados a grupos especificos e não são suficientes para delinear o perfil de saúde bucal da população de escolares ou da população como um todo.

A cidade apresenta, assim, um contexto diverso de atenção em saúde bucal, principalmente no que se refere aos escolares. Não é possivel descrever claramente a condição de saúde bucal desse grupo, havendo evidência de que a assistência odontológica no município é caracterizada tanto no setor público quanto privado pela livre demanda em função da busca de ações curativas.

A escassez de dados sobre saúde bucal em municípios com Faculdades de Odontologia não é uma caracteristica de Feira de Santana. PERES, NARVAI e CALVO (1997) verificaram que dentre vinte municipios do Estado de São Paulo com faculdades, apenas cinco dispunham de dados de saúde bucal na idade indice de doze anos. Mas, o empenho na condução de um trabalho conjunto dos grupos de pesquisa das faculdades com os gestores em saúde pública permitiram a mudança desse quadro, com a realização de vários levantamentos das condições de saúde bucal da população em diferentes municípios do Estado de São Paulo (FERNANDEZ et al. 1999; FREIRE et al. 1999; BASTOS et al. 2002; SALES-PERES e BASTOS 2002). 
Em Feira de Santana, QUEIROZ (2002), ao analisar as politicas públicas do municipio relacionadas à qualidade de vida relata que a UEFS tem buscado, através da formação de recursos humanos, fortalecer os quadros das secretarias estadual e municipal de saúde, especialmente no âmbito da pós-graduação, embora se considerem as diferentes lógicas da academia, como lócus de discussão das idéias e dos serviços que representam a prática propriamente dita.

Segundo PINTO VG (1996), o diagnóstico básico da população é necessário para instrumentar a programação e o planejamento dos serviços de saúde em geral e de odontologia em particular.

Os levantamentos epidemiológicos em saúde bucal têm merecido considerações e investigações em nível universal, dada a importância que os estudos deste cunho têm como referência à implantação de sistemas de prevenção e tratamento (NORMANDO e ARAÚJO 1990).

Desta forma, frente a lacuna de informações observada e visando cumprir os objetivos traçados ao curso de Doutorado em Saúde Pública, surgiu a motivação em caracterizar a saúde bucal dos escolares com doze anos de idade na zona urbana de Feira de Santana - Bahia. Esse grupo populacional foi escolhido devido ao fato que todos os dentes permanentes, exceto os terceiros molares, se encontram erupcionados e por ser a idade preconizada pela Organização Mundial de Saúde para o monitoramento global dos índices de cárie dentária (WHO 1987, 1997).

O trabalho aqui descrito se propôs a contribuir, através do diagnóstico dessa realidade, para a elaboração e embasamento de programas que visem assegurar a saúde bucal desse grupo. 


\section{REVISÃO DE LITERATURA}

\subsection{SAÚDE BUCAL COLETIVA}

Durante muitos anos predominou o pensamento clínico sobre o processo saúde-doença. Neste contexto, a saúde era entendida ou representada como ausência de doença e a organização dos serviços era medicamente definida e tendo como objetivo colocar à disposição da população serviços preventivos e curativo-reabilitadores acessíveis, de conformidade com os elementos do flexnerianismo (MENDES 1996).

A partir dos anos 70 , surgem novas concepções de processo saúdedoença (modelos de Blum, de Dever e de Lalonde) que procuraram articular quatro dimensões explicativas: biologia humana, estilos de vida, meio ambiente e serviços de saúde. Essas novas concepções são mais globalizantes e articulam saúde com condições de vida. Saúde é, então, resultado de um processo de produção social que expressa a qualidade de vida de uma população, entendendo-se a qualidade de vida como uma condição de existência dos homens no seu viver cotidiano, um "viver desimpedido", um modo de "andar a vida" prazeroso, seja individual, seja coletivamente. $O$ que pressupõe determinado nivel de acesso a bens e serviços econômicos e sociais (MENDES 1996).

O conceito moderno considera que saúde ocorre em um gradiente e que a determinação do processo saúde/doença deve ser vista de forma integral, onde, saúde e doença são estados integrantes de um mesmo processo e, portanto, a saúde pública nos leva à noção de intervenção sobre determinantes e risco, atuando no indivíduo. Desta forma, saúde pública é tudo que se refira à saúde: diagnosticar, conhecer, identificar os processos envolvidos no gradiente de saúde e seus efeitos, intervir sobre esses processos para controlar o risco de adoecer e morrer, e além disto avaliar o processo; ou seja,o que está envolvido com a saúde da população, do indivíduo que está inserido no coletivo. $O$ objetivo último da saúde pública é a atenção individual e consequentemente do coletivo, uma vez que não existe a "doença" no público e sim no indivíduo. Logo, todo profissional que 
tenha algum grau de relação na sua atividade de trabalho com a questão de saúde e as condições que participam do seu gradiente irá exercer uma função de saúde pública de forma positiva ou negativa (ALMEIDA, CASTRO e VIEIRA 1998).

Saúde Pública, numa definição prática, é o diagnóstico científico dos problemas de saúde de uma comunidade e a aplicação de medidas individuais e coletivas para controlar esses problemas, evitando sua progressão ou reduzindo sua ocorrência para niveis suportáveis do ponto de vista econômico e aceitáveis do ponto de vista social. Portanto, transcende a saúde no plano individual e não deve ser confundida com "saúde estatal" ou aquela realizada apenas pelo Estado. Organizações não estatais podem e devem implementar medidas coletivas que favoreçam a saúde de seus usuários. Por estas e outras razões, denomina-se esta área de conhecimento Saúde Coletiva (FRAZÃO 1999).

Significa dizer que a mudança das condições de saúde requer a construção social de um projeto para a sociedade. Pois, muito embora as desigualdades não sejam necessariamente produzidas no campo da saúde são reproduzidas e perpetuadas neste âmbito (ESCOREL 1994).

Neste sentido, um grande passo foi dado nos artigos 196 a 200 da Constituição Brasileira de 1988, onde a saúde foi assumida como doutrina básica, sendo a qualidade de vida inserida nos direitos sociais e tratada como complexo único, integral, assegurada como um dever do Estado e um direito do cidadão (MENDES 1996).

Esta nova legitimidade da saúde na Constituição em conjunto com as ações propostas pelo movimento da Reforma Sanitária desencadeou a proposta do SUS (Sistema Único de Saúde), o qual incorpora o conceito de saúde individual, de saúde pública e é uma política de saúde, um programa que apresenta um potencial de realizações. Ou melhor, um processo que visa a democratização e a justiça social. Pois, uma característica importante do SUS é a possibilidade da participação social em seus direcionamentos e a integralidade de ações proposta em sua unicidade (CHIORO e SCAFF 1999). 
Ao mesmo tempo em que ocorreram esse movimento e as mudanças de enfoque na abordagem da saúde, realizou-se a crítica da prática da odontologia que vinha sendo realizada no país. A Odontologia Brasileira tem se caracterizado em ser uma área de atuação elitista, de tecnologia de ponta, cara e não acessível à grande maioria da população. Os dados de nossa realidade demonstram que apesar de todos avanços científicos em odontologia pouco se tem feito para efetivamente melhorar as condições de saúde bucal da população (GARRAFA 1993).

Adicionalmente, o setor da Saúde Bucal passou a ter o privilégio de conhecer de forma bem definida o processo de desenvolvimento das doenças bucais mais prevalentes: a cárie e a doença periodontal. Este conhecimento proporcionou a possibilidade de não atuar nos sinais da doença, mas sim de promover a saúde, atuando nas causas da doença (WEYNE 1997). Sendo os marcos referenciais do paradigma de promoção de saúde bucal:

- a descoberta do processo saúde/doença da cárie e doença periodontal;

- a comprovação da eficácia pré e pós-eruptiva de compostos fluoretados na prevenção de cárie;

- o desenvolvimento de métodos clínicos para diagnóstico precoce e monitoramento destas doenças;

- a possibilidade do retardo na colonização de crianças pelos microorganismos cariogênicos, através do controle da infecção em suas mães;

- o tratamento não é pontual, precisa ser contínuo;nas causas das doenças;

- o controle de infecções cruzadas e a biossegurança em consultórios;

- a necessidade de atendimento multidisciplinar;

- a comprovação que doenças bucais podem provocar doenças sistêmicas.

MARCENES e BÖNECKER (2000) afirmaram que um pré-requisito para o sucesso da promoção de saúde da população é o conhecimento da 
epidemiologia das doenças bucais. Relataram que a epidemiologia é um instrumento político muito poderoso, pois tanto a escolha do programa de prevenção e tratamento das doenças bucais, como o planejamento de serviços odontológicos, são determinados pelo resultado de estudos epidemiológicos.

Com a consolidação do processo de Reforma Sanitária e com a emergência do paradigma de promoção de saúde, nos finais dos anos 80 e início dos anos 90 ocorreu o surgimento da Saúde Bucal Coletiva (SBC).

A Saúde Bucal Coletiva pretende substituir toda forma de tecnicismo e de biologismo presentes nas formulações específicas da área da odontologia social e preventiva (FRAZÃO 1999).

A Saúde Bucal Coletiva enquanto paradigma de programação deve ser entendida como a Odontologia exposta às exigências e aos desafios do SUS. Na qual, quatro linhas programáticas se destacam:

- programação centrada nas unidades básicas de saúde;

- programação com ênfase preventiva da inversão;

- vigilância da qualidade da fluoretação das águas de abastecimento público;

- programação com ênfase promocional do Programa de Saúde da Familia (ZANETTI et al. 1996).

A Saúde Bucal Coletiva tem hoje a tarefa de mudar o modelo de programação enfatizando o preventivo e o promocional no sentido de modificar a situação epidemiológica, a forma de atenção e ainda resgatar a saúde bucal como condição de cidadania, dentro das condições reais de organização dos serviços, disponibilidades financeiras e de recursos humanos no mundo em desenvolvimento (ZANETTI et al. 1996).

A Saúde Bucal Coletiva tem procurado se constituir em referência de uma práxis capaz de recuperar para o trabalho em odontologia suas dimensões política, social, comunitária, preventiva e integral indispensáveis às práticas no campo da saúde que tenham como horizonte sociedades democráticas e solidárias, nas quais as questões de saúde-doença tenham, 
efetivamente, relevância pública e assim sejam consideradas pelo Estado e pelo conjunto da sociedade (NARVAI 2002).

Dentro da perspectiva da promoção de saúde e da construção de uma prática de saúde bucal coletiva é que este trabalho se desenvolve, mediante os conhecimentos atuais sobre a etiopatogenia dos principais problemas de saúde bucal e utilizando a epidemiologia para o levantamento destes problemas no municipio de Feira de Santana, de modo a possibilitar que as programações coletivas em saúde sejam epidemiologicamente orientadas.

\subsection{OS PROBLEMAS DA SAÚDE BUCAL COLETIVA}

Segundo CHAVES (1986), a forma mais didática que se conhece para caracterizar um problema de saúde coletiva é a proposta de Sinai, onde para um problema ser considerado de saúde pública precisa preencher três condições essenciais:

$1^{\text {a }}$ constitui causa comum de morbidade e mortalidade;

$2^{\mathrm{a}}$ existem métodos eficazes de prevenção e controle;

$3^{\text {a }}$ tais métodos não estão sendo utilizados de modo adequado pela comunidade.

Uma vez reunidas essas condições, os problemas deverão ser dispostos em uma hierarquia própria, segundo uma ordem de importância, de acordo com seu significado social.

Dependendo da região, (fatores ligados ao lugar) em que é realizada a análise e das características circunstanciais do grupo populacional em estudo (fatores ligados à pessoa) e ainda ao tempo variam a distribuição e o grau de importância de problemas de saúde-doença no coletivo (ROUQUAYROL 1994).

MENDES (1996) mediante a nova prática sanitária da vigilância da saúde, relatou que por problema de saúde deve-se entender a representação social de necessidades sanitárias, derivadas de condições de vida e formuladas por determinado ator social, com base em uma percepção de uma discrepância entre a realidade e uma norma instituída. A 
identificação, descrição e análise de problemas não se fazem independentemente de quem e de que posição identifica, descreve e explica.

Na Política Nacional de Saúde Bucal, aprovada em 1989 (MINISTÉRIO DA SAÚDE 1989a), os problemas de saúde bucal eram, em ordem decrescente de prioridade: a cárie dentária, as doenças periodontais, problemas dentomaxilofaciais/ortodônticos e câncer bucal.

Atualmente, os dados epidemiológicos têm demonstrado uma tendência de declínio da cárie em crianças que acontece de maneira diferente em vários locais. Ainda assim, os estudos epidemiológicos se fazem necessários, destacando-se agora a exigência de melhor compreensão dos motivos que estão ocasionando esta menor incidência de cárie e o por quê disso estar acontecendo apenas em alguns estados (PINTO VG 1997).

Além disto, a cárie dentária nem sempre é o principal problema e qualquer um dos outros pode ser mais relevante do ponto de vista social e sanitário (FRAZÃO 1999). Isto implica em reconhecer que o estabelecimento de prioridades para um determinado grupo ou população deve se pautar no levantamento das condições de saúde bucal deste grupo, para o reconhecimento de qual o principal problema a ser enfocado, seja ele cárie, doença periodontal, ou outros.

Em consequência do declínio da prevalência e severidade da cárie dentária que tem sido relatado, acredita-se que as doenças periodontais devam ocupar o foco de atenção dos profissionais de odontologia, constituindo-se no principal problema de saúde pública, em saúde bucal. Esse fato já é observado em paises desenvolvidos, onde a cárie dentária foi controlada ou desapareceu (MARQUES 2000).

Em relação às oclusopatias, o campo de trabalho é amplo e pouco explorado. Poucos serviços de saúde têm um setor ou um programa de trabalho voltado para esse problema, ficando a maioria da população com necessidades acumuladas e sem acesso tanto aos recursos mais simples de prevenção quanto àqueles de tratamento mais complexo (FRAZÃO 1999). 
Vários trabalhos evidenciam a constatação de que tem aumentado o nivel de fluorose dentária nas populações em vários locais do mundo (CANGUSSU et al. 2002; CLARK et al. 1994; BELTRÁN-AGUILAR, GRIFFIN e LOCKWOOD 2002; BOWEN 2002; BUZALAF, CURY e WHITFORD 2001; ISHII e SUCKLING 1991; LEWIS e BANTING 1994; PEREIRA et al. 2001; RIORDAN e BANKS 1991).

Embora a fluorose dentária nem sempre seja um problema de saúde pública, isto não exime a responsabilidade de detectar sua prevalência e os fatores envolvidos para que a redução de cárie observada no Brasil continue sem traumas (CURY 1998).

Mediante a necessidade do estudo das condições de saúde-doença da população e dos principais fatores causais associados, bem como para subsidiar o planejamento-avaliação das ações na área de Saúde Bucal nos diferentes níveis de Gestão do Sistema Único de Saúde, a Área Técnica de Saúde Bucal do Ministério de Saúde do Brasil planejou o Projeto de Saúde Bucal - 2000 para identificação dos seguintes problemas: cárie dentária, doença periodontal, oclusopatias, fluorose dentária e uso/necessidades de prótese (MINISTÉRIO DA SAÚDE 2000). Este projeto se encontra em fase de operacionalização para a sua execução.

Aspectos etiológicos e epidemiológicos dos principais problemas de saúde bucal coletiva serão relatados a seguir.

\subsubsection{CÁRIE DENTÁRIA}

Existem relatos da existência de cárie desde a Pré-história. Lesões de cárie foram detectadas em niveis muito reduzidos em um esqueleto de Australopithecus que viveu entre 500 mil e 1 milhão de anos atrás, num Homo Erectus do Plistocênio Médio e em alguns Homo Neanderthal do final da Era Plistocênia. A cárie, nos niveis de prevalência hoje conhecidos, é uma doença típica dos tempos modernos que se desenvolveu e expandiu nas sociedades mais avançadas, notadamente a partir do Século XVII (PINTO VG 1990). 
No Século 19, o conhecimento da época se fundamentava na hipótese de que a cárie era resultado da produção coletiva de ácidos por bactérias orais através de um substrato fermentável, cuja sustentação científica se baseava na teoria quimioparasitária apresentada por Miller em 1890 (WEYNE 1989; LOESCHE 1993).

No início dos anos cinqüenta, se iniciaram as primeiras pesquisas de cárie em animais experimentais. Foi demonstrado que ratos assépticos não desenvolviam cárie, mesmo quando expostos a uma dieta rica em carboidratos fermentáveis. Mas, quando estes animais, mantidos nessa mesma dieta, eram infectados com enterocococos capazes de produzir ácidos, a cárie então se desenvolvia (ORLAND et al 1954).

Em 1960, em estudo experimental com hamsters, o cárater infeccioso e transmissivel da cárie começou a ser descrito. Neste estudo, ficou demonstrado que animais cárie-resistentes diferiam de animais cárie-ativos, porque não possuiam determinados microorganismos. Sendo que a transmissão dos microorganismos entre os animais ocorria simplesmente ao colocá-los na mesma gaiola ou pela inoculação de excrementos dos animais cárie-ativos nos cárie-resistentes (KEYES 1960).

Logo em seguida, FITZGERALD e KEYES (1960) isolaram os microrganismos responsáveis pelo desenvolvimento das cáries nos animais cárie-resistentes e descreveram o papel dos estreptococos na etiologia da cárie.

Em humanos, a transmissibilidade da cárie, teve comprovação científica quando foi demonstrado que a contaminação de crianças com estreptococcos cariogênicos ocorria a partir de seus pais ou outras pessoas do convivio freqüente e ainda que medidas preventivas implementadas em mães influenciavam o nivel de infecção por bactérias cariogênicas em seus filhos (KÖHLER e BRATTHALL 1978; KÖHLER et al 1982; 1983).

Portanto, a cárie é reconhecida atualmente como uma doença infectocontagiosa, que possui características multifatoriais essenciais em sua etiologia, com fatores relacionados ao hospedeiro, representado pelos 
dentes e pela saliva, à dieta consumida e à microbiota da placa dental (KRASSE 1988; WEYNE 1989).

A cárie é conseqüente da produção de ambiente ácido ( $\mathrm{pH}$ ácido) por microorganismos colonizadores da placa bacteriana que favorece a perda de elementos minerais da estrutura dentária (esmalte, dentina e cemento). Para que a doença ocorra é necessária a interação, durante um determinado tempo, dos seguintes fatores: um hospedeiro suscetivel (dente); microorganismos específicos (capazes de produzir ácidos e sobreviver em meio ácido) e uma dieta alimentar rica em açúcares (LOESCHE 1993; WEYNE 1989).

A perda de minerais da estrutura dentária (desmineralização) ocorre após a ingestão de açúcares e baixa de $\mathrm{pH}$. Quando $0 \mathrm{pH}$ retorna à normalidade, principalmente devido a ação da saliva e a remoção dos açucares da cavidade bucal, ocorre a recuperação dos minerais perdidos (remineralização). As lesões de cárie são decorrentes do desequilibrio entre os processos de des-remineralização e são sinais da doença (THYLSTRUP e FEJERSKOV 1988).

O processo de formação da cárie não acontece durante todo o tempo e sim em sucessivos ataques à estrutura dental após as sucessivas ingestōes de açúcares. Este processo evolui de uma perda mineral ultra-estrutural, lesão microscópica, a lesão inicial visivel clinicamente até a formação de cavidade e destruição total do dente (THYLSTRUP e FEJERSKOV 1988).

LOESCHE (1993) destacou que a cárie dentária é uma infecção tratável causada por um número limitado de espécies bacterianas, que inclui os Streptococcus do grupo mutans, Lactobacillus e Actinomyces viscosus. KRASSE (1988) ressaltou também que é a função dos microorganismos e não o número total de bactérias da placa, que determina se irá ou não ocorrer perda mineral.

A dieta alimentar pode influenciar na composição da microbiota e em suas atividades metabólicas, através da composição química do alimento, de sua consistência física e da freqüência de ingestão. Carboidratos com peso 
molecular baixo, como a sacarose, glicose e lactose, podem facilmente se difundir na placa e serem imediatamente metabolizados pelas bactérias orais (LOESCHE 1993; THYLSTRUP e FEJERSKOV 1988; KRASSE 1988).

Os conceitos que predominam sobre os fatores mais importantes no papel da dieta no desenvolvimento da cárie são a frequência de ingestão, a concentração e aderência dos subprodutos de açúcar por estarem relacionados ao tempo de eliminação do açúcar da cavidade bucal (KRASSE 1988). Recentemente tem sido demonstrado que a ingestão, mesmo freqüente, tem seu efeito minimizado quando se tem uma boa higiene oral. SAMPAIO et al (2000) verificaram em crianças de áreas rurais, com baixo ou moderado teor de flúor na água de abastecimento, no Estado da Paraiba Brasil, que os índices de cárie foram correlacionados com baixos Índices de Higiene Oral e com a baixa freqüência de ingestão de açúcar entre as refeições.

Quanto ao hospedeiro, fatores individuais relacionados à qualidade e o estado do esmalte dentário, superfícies dentais retentivas à placa bacteriana, nivel de infecção por bactérias cariogênicas e a capacidade tampão/fluxo salivar devem ser investigados. No entanto, como não se pode possuir superficies dentárias estéreis (MALTZ 2000) dada à continua formação de placa bacteriana, assim várias medidas de intervenção têm sido direcionadas aos esforços para se manter concentrações mínimas de bactérias nas superfícies dentárias (LOESCHE 1993).

Ao compreender o processo de formação da cárie, percebe-se que um indivíduo pode estar com a doença e ainda não apresentar clinicamente os seus sinais, as lesões e cavidades. É importante ressaltar que mesmo ao se deparar com um individuo que esteja apresentando os primeiros sinais clinicos da doença, lesões de mancha branca opacas, a remineralização destas lesões é possivel. Desta forma, interrompe-se a evolução do processo de cárie até a formação de cavidade dentária, que é uma perda estrutural irreversivel (THYLSTRUP e FEJERSKOV 1988). 
Portanto, na abordagem à cárie dentária dentro do paradigma de promoção de saúde, procura-se interferir no curso do processo da doença através do controle dos fatores implicados em sua etiologia e não apenas 0 tratamento curativo dos seus sinais. A determinação do risco de um indivíduo para a doença mediante a análise dos fatores envolvidos deve ser realizada; ou seja, quanto maior a quantidade de fatores presentes maior o risco do indivíduo e mais intensa se faz a necessidade de medidas de controle (MALTZ 2000).

Atualmente, o diagnóstico da doença cárie passou, da simples enumeração de lesões, para um diagnóstico abrangente dos fatores etiológicos, determinantes e modificadores da doença, atuantes no indivíduo ou na população (MALTZ e CARVALHO 1997).

Além dos fatores determinantes anteriormente descritos, MALTZ (2000) relatou uma série de outros fatores, ditos, mascaradores, que interferem no processo das doenças, em geral e da cárie em particular, compondo o meio biopsicossocial onde o individuo está inserido. Entre eles, estão o comportamento e as atitudes perante a vida, o nivel sócio econômico, etc. Esses fatores envolvem limitações e hábitos inerentes a grupos ou populações assumindo importância fundamental (BALDANI, NARVAl e ANTUNES 2002; FREIRE 2000; GONÇALVES, PERES e MARCENES 2002; MALTZ E SILVA 2001; MANDEL 1996; NADANOVSKY e SHEIHAM 1995; PERES 2002).

LOCKER, CLARKE e MURRAY (1988) relataram diferenças entre o nivel de saúde bucal de adolescentes canadenses e imigrantes que foram correlacionadas a diferentes acessos ao serviço odontológico neste grupo.

Quando a qualidade de vida e a tendência de um comportamento prósaúde bucal estão integradas, os critérios para julgamento tornam-se mais racionais e é possivel propor um tratamento em dimensões mais amplas, incorporando-as a sistemas que proporcionem diretrizes básicas a fim de combinar as medidas clínicas com as sociopsicológicas em relação à saúde e às necessidades de tratamento (SHEIHAM 2000). 
Exames detalhados de estudos epidemiológicos demonstram que existe uma demarcada polarização na distribuição da cárie em crianças: $20,0 \%$ possuem $60,0 \%$ da cárie (MANDEL 1996).

As indicações provenientes de estudos epidemiológicos de que as lesões de cárie não se distribuem homogeneamente nas pessoas e nas populaçōes, uma vez que certos indivíduos ou grupos são responsáveis pela maioria das cáries nas populações, revelam a importância da detecção precoce destas pessoas em Saúde Pública (WEYNE 1989).

Para a mensuração da prevalência, do ataque e da severidade da cárie dentária em populações está consagrada a utilização do índice CPOD (Cariados, Perdidos e Obturados - Dentes) descrito por Klein e Palmer, em 1937, o qual tem sido preconizado pela Organização Mundial de Saúde (WHO 1987, 1997) e tem sido utilizado para comparações globais do nivel de cárie dentária. Os critérios, códigos e forma de cálculo estão apresentados no capitulo Material e Métodos.

A Organização Mundial de Saúde (WHO 1987) estabeleceu faixas para classificação do nível de prevalência em populações utilizando como indicador o valor médio do índice CPOD aos doze anos de idade:

- CPOD de 0,0 a 1,1 : prevalência muito baixa;

- CPOD de 1,2 a 2,6 : prevalência baixa;

- CPOD de 2,7 a 4,4 : prevalência moderada;

- CPOD de 4,5 a 6,5 : prevalência alta;

- CPOD de 6,6 ou mais : prevalência muito alta.

PINTO VG (2000) referiu que tem se tornado evidente a limitação das práticas clássicas de medição dos problemas odontológicos e das resultantes indicações de tratamento. Adicionadas às dimensões clínicas, dependentes do critério profissional, as raízes sociais e econômicas só podem ser suficientemente compreendidas e explicadas quando seus 
portadores são ouvidos e quando os autodiagnósticos e opiniões destas pessoas são tomados em consideração.

Neste sentido, alguns índices têm sido criados visando avaliar aspectos relacionados à qualidade de vida das pessoas e sua saúde bucal, a exemplo do IODD (Índice de Impactos Odontológicos no Desempenho Diário) proposto por Adulyanon e Sheiham (1998) citado por (SHEIHAM 2000).

Sobre as principais medidas de prevenção à cárie dental destacam-se: - controle da dieta, a orientação da higiene bucal, a monitorização de bactérias cariogênicas e o uso do flúor (MALTZ e CARVALHO 1997).

No controle de dieta recomenda-se ao indivíduo a diminuição da quantidade de açúcares ingerida, bem como a redução da frequência de ingestões. Também pode ser proposta a utilização de açúcares não cariogênicos como sorbitol, xilitol e manitol (KRASSE 1988; MANDEL 1996).

A orientação de higiene bucal objetiva habilitar o indivíduo a realizar uma eficiente remoção da placa bacteriana, buscando esclarecê-lo quanto à seleção de escova, fio e pasta dental e método de escovação (CARVALHO e MALTZ 1997).

A monitorização das bactérias cariogênicas se faz com exames microbiológicos, em meios seletivos para Streptococcus mutans e Lactobacillus, após coleta de amostras da placa bacteriana ou saliva. Valores a partir de 1.000 .000 e 100.000 , respectivamente, representam indivíduos com alto risco e atividade de cárie. Nestes casos o uso de antimicrobianos, em bochechos, para diminuir estes valores pode ser instituido e monitorizado (KRASSE 1988).

Com relação ao uso do flúor, é relatada sua ação direta no processo de des-remineralização quando presente na cavidade bucal, favorecendo a reposição de íons e incorporando-se ao esmalte dental; bem como sua ação durante a fase de formação do elemento dentário através de seu adequado uso sistêmico (CURY 1989). A participação do flúor no processo de desremineralização está descrita no ítem Fluorose Dentária. 
Vários métodos de utilização do flúor estão atualmente disponiveis: soluções fluoretadas para bochecho, pastas dentais e aplicação tópica profissional com géis ou vernizes; enquanto que os sistêmicos são: suplementação de flúor ou o uso de água fluoretada. Sendo este último, uma ação do município no Sistema de Abastecimento de Água e uma medida de saúde pública eficaz e de ampla cobertura populacional, além de ser acessivel quando se avalia o seu baixo custo em relação ao benefício alcançado (NARVAl et al. 2002).

Durante as três últimas décadas, tem sido observado um declínio da doença cárie em níveis populacionais (PINTO VG 1997), dentre os fatores que vem sendo descritos como os principais responsáveis por esta redução destacam-se: a disponibilidade de fluoretos, especialmente 0 uso generalizado de dentifrícios fluoretados; a disponibilidade de cuidados odontológicos; aumento da "consciência odontológica" junto com uma crescente utilização dos serviços odontológicos; a postura preventiva adotada pelos profissionais; a mudança na qualidade geral de vida e a institucionalização de programas de educação em saúde bucal (PINTO VG 1990).

No Brasil, a tendência mundial de declínio da doença cárie também tem sido observada. Em 1986, segundo levantamento epidemiológico realizado pela Divisão Nacional de Saúde Bucal ficou evidente a precariedade em que se encontrava a população brasileira em relação às doenças bucais mais prevalentes: cárie dentária e doença periodontal. Neste levantamento, a criança aos doze anos de idade possuía, em média, 6,7 dentes comprometidos pela doença cárie. No grupo etário de 35 a 44 anos um em cada dois brasileiros, aproximadamente, se encontrava totalmente desdentado (MINISTÉRIO DA SAÚDE 1988).

Dez anos depois, essa mesma Divisão realizou um novo levantamento nas capitais brasileiras e verificou, salvo restrições metodológicas que têm sido feitas a este trabalho, uma redução de $50 \%$ do índice de cárie em 
crianças com doze anos de idade (CPOD médio igual a 3,06) (MINISTÉRIO DA SAÚDE 1996).

Também, o estudo nacional efetuado em escolas públicas e em escolas do SESI em 1993, que embora não tenha sido desenhado especificamente para diagnosticar a prevalência de cárie em nivel nacional transformou-se em um importante ponto de referência e de comparação com o estudo de 1986, por ter usado os mesmos critérios e por sua amplitude, demonstrou uma diminuição consistente da prevalência de cárie em relação ao levantamento de 1986, a qual aos doze anos de idade (CPOD médio igual a 4,84) foi de 27,48\%(SESI 1995; PINTO VG 1997).

Esta tendência de declínio da doença cárie tem sido relatada em várias regiōes e cidades do país, tais como São Paulo (NARVAl e FERNANDES 1999), Florianópolis (FREYSLEBEN, PERES e MARCENES 2000), entre outras, sendo evidenciado como ponto comum nestes locais a realização de medidas preventivas de ampla cobertura populacional, tais como a fluoretação da água de abastecimento e a implementação de programas de educação em saúde bucal e de atenção ao escolar.

Outro ponto a ser destacado em relação a redução de cárie é a Portaria $\mathrm{n}^{\circ} \mathbf{2 2}$ de 20 de dezembro de 1989 da Secretaria Nacional de Saúde e Vigilância Sanitária, que regulamenta a incorporação do flúor às pastas dentais comercializadas no país (MINISTÉRIO DA SAÚDE 1989b).

A literatura mundial sobre a cárie dentária é farta, mas neste trabalho serão relatados a seguir estudos epidemiológicos que levantaram as prevalências e severidade de cárie dentária no território nacional.

SOUZA et al (1967) investigaram a prevalência de cárie dentária em "brancos" e "não brancos" em 378 crianças de oito a doze anos de idade, em São Paulo - SP. Observaram diferenças estatísticas para as idades de oito, onze e doze anos com maior prevalência de cárie entre os "brancos".

CASTELLANOS (1974) também examinou 860 escolares internos em orfanatos da cidade de São Paulo procurando identificar diferenças no CPOD entre "brancos" e não "brancos". Os resultados demonstraram 
diferenças significativas entre os sexos e uma maior prevalência de cárie em crianças "brancas".

TOMITA et al. (1994) avaliaram a prevalência de cárie em crianças de zero a seis anos matriculadas em creches de Bauru e São Paulo, sendo que o primeiro grupo não recebia cuidados de saúde na instituição e o segundo apresentava uma rotina de cuidados como norma institucional. Não foram observadas diferenças entre os sexos, mas a prevalência de cárie foi mais elevada no grupo de Bauru.

MOREIRA, PEREIRA e OLIVEIRA (1996) avaliaram a prevalência de cárie dentária em escolares de sete a catorze anos da cidade de Paulínia $\mathrm{SP}$, através da comparação dos dados de levantamentos realizados em 1980 e 1994. Em 1980, o valor médio do CPOD aos doze anos era 8,2 enquanto que em 1994 foi igual a 3,0; demonstrando uma redução percentual de $81,2 \%$.

FREIRE, MELO e SILVA (1996) investigaram a prevalência de cárie na dentição decidua em 2.267 crianças pré-escolares de creches de Goiânia GO e sua relação com o nivel socioeconômico. Foram identificadas diferenças significativas quanto ao percentual de crianças livres de cárie, $48,3 \%$ nas creches privadas e $28,2 \%$ nas públicas, bem como o CPOD e a proporção de dentes cariados foram maiores nas escolas públicas.

A importância de fatores socioeconômicos em relação à prevalência da cárie dentária foi investigada por TOMITA et al. (1996) em crianças de zero a seis anos matriculadas em creches de Bauru - SP e São Paulo. Os resultados não demonstraram diferenças entre os sexos e entre as variáveis estudadas, os fatores que apresentaram influência significativa sobre a experiência de cárie foram a idade e a freqüência de consultas odontológicas.

FREIRE et al. (1997) estimaram a prevalência de cárie e as necessidades de tratamento em 1.400 escolares de seis a doze anos de idade em Goiânia - GO, através dos dados de levantamento epidemiológico 
em saúde bucal realizado em 1994, e verificaram uma prevalência de cárie alta, com o valor médio do CPOD aos doze anos igual a 4,59.

PERES, NARVAI e CALVO (1997) avaliaram a prevalência de cárie em crianças de doze anos de idade através dos dados das secretarias municipais de saúde de cento e vinte e cinco municípios do Estado de São Paulo. O estudo revelou que em apenas $4,0 \%$ dos municípios a prevalência de cárie dentária era baixa, sendo alta ou muito alta em cerca de $80,0 \%$. A média estimada do CPOD para o Estado de São Paulo foi 4,8.

A prevalência de cárie e de necessidades de tratamento em 1419 escolares de seis a doze anos, em nove municípios do Estado de Goiás, foram estimadas por FREIRE et al. (1999). Aos doze anos o valor médio do CPOD foi igual a 5,19 , sendo que apenas $4,4 \%$ das crianças estavam livres de cárie.

BOTTAN et al. (1999) avaliaram a eficácia do programa implantado na rede municipal de ensino de Rio do Sul - SC, sendo que 872 crianças com idade até doze anos foram examinadas. Foi observada uma redução de $81,02 \%$ na prevalência de cárie no município, que saiu de uma prevalência muito alta $(6,8)$, em 1991, para baixa $(1,29)$ em 1998. Os autores registraram também que quanto maior era o nivel de escolarização da criança maior era a freqüência de escovações diárias.

No Estado de São Paulo, após a realização do levantamento epidemiológico em saúde bucal, em 1998, NARVAI e FERNANDES (1999) verificaram um declínio de $48,0 \%$ da prevalência de cárie aos doze anos de idade. Diferenças no percentual de crianças livres de cárie foram registradas entre escolas públicas $(19,0 \%)$ e privadas $(47,0 \%)$.

TOMITA et al. (1999) avaliaram as preferências pelo sabor doce e a sua associação com as condições socioeconômicas e a prevalência de cárie dentária em 572 pré-escolares de quatro a seis anos de idade. Os resultados demonstraram diferenças significativas entre crianças de diferentes grupos socioeconômicos quanto à preferência pelo sabor doce e o consumo de 
açúcar, bem como associação entre o menor percentual de crianças livres de cárie e o nivel sócio econômico mais baixo.

No município de São Paulo - SP, NARVAI, CASTELLANOS e FRAZÃO (2000) analisaram a prevalência da cárie dentária, em 2.491 escolares de cinco a doze anos de idade, com base nos dados do levantamento epidemiológico em saúde bucal realizado em 1996 (USP/FSP 1997). Os componentes cariado e obturado do índice apresentaram freqüências semelhantes nas idades de cinco, seis e sete anos. A partir dos nove anos houve um aumento do componente obturado. Em todas as idades houve uma participação pouco expressiva do componente perdido. Apesar das escolas públicas apresentarem maior CPOD aos doze anos, não foram registradas diferenças estatísticas. $O$ fenômeno da polarização foi observado.

FREYSLEBEN, PERES e MARCENES (2000) compararam a prevalência de cárie e o CPO-D médio em escolares de doze a treze anos de idade registrados em Florianópolis - SC em 1971 e 1997. Identificaram uma redução de $31,2 \%$ da prevalência de cárie e não ocorreram diferenças entre as freqüências segundo o sexo.

PATUSSI (2000) descreveu as desigualdades existentes na distribuição da cárie dentária em 1.025 escolares de diferentes regiões socioeconômicas do Distrito Federal, em 1997. Areas mais abastadas possuiam uma menor severidade de cárie dentária quando comparadas às outras regiões. A prevalência da doença foi fortemente associada com fatores socioeconômicos.

MORAIS, LENZA e FREIRE (2000) estudaram a prevalência de cárie em 446 escolares de seis a doze anos de idade em Dom Aquino - MT. Verificaram uma prevalência de cárie muito alta em todas as idades. Aos doze anos, o valor médio do CPOD foi 6,97 , sendo que apenas $0,03 \%$ das crianças nessa idade se encontravam livres de cárie. Em todas as idades, o componente cariado contribui para a maior parte do CPOD. 
Um estudo de prevalência sobre a distribuição da cárie dentária nos usuários, de três a sessenta anos, do SUS em Belo Horizonte - MG foi realizado por SANTOS, PORDEUS e FERREIRA (2000). Aos doze anos o valor médio do CPOD foi 2,7 , sendo o percentual de livres de cárie igual a $17,2 \%$.

A análise do perfil epidemiológico da cárie dentária, entre escolares de doze anos, em Bauru - SP, com os dados dos levantamentos dos anos 1976, 1984, 1990 e 1995 foi realizada por BASTOS et al. (2002). Foi observada uma redução de cárie no período de $58,24 \%$, passando o CPOD de 9,89 em 1976 para 4,13 em 1995. O fenômeno da polarização da cárie dentária também foi observado.

SALES-PERES e BASTOS (2002) analisaram o perfil epidemiológico da cárie dentária na Região Centro-Oeste do Estado de São Paulo, em crianças de doze anos de idade, comparando o índice CPOD em municípios fluoretados e não fluoretados. Os resultados demonstraram que na cidade de Pederneiras (médio porte, com flúor), O CPOD foi igual a 7,06, valor maior do que o encontrado no Brasil em 1986. A maior prevalência de cárie ocorreu entre os meninos. Entre os municipios de mesmo porte, independente da presença ou ausência de flúor na água, não houve diferença entre os indices CPOD registrados, possivelmente devido a ação de outras fontes de flúor. A prevalência de cárie na região foi alta, com CPOD igual a 4,82 .

TRAEBERT et al. (2002) estudaram a prevalência e severidade de cárie dentária e necessidade de tratamento em São João do Sul - SC e Treviso - SC. Um censo da população escolar de seis a doze anos foi realizado. As prevalências de cárie encontradas foram $62,1 \%$ e $63,6 \%$, respectivamente. $O$ valor médio do índice $C P O D$ nas duas cidades $(1,91 \mathrm{e}$ $1,84)$ demonstrou uma baixa prevalência de cárie.

A análise dos trabalhos relatados demonstra que existem prevalências de magnitude diferentes em vários municípios ou regiões brasileiras. 
Portanto, o diagnóstico epidemiológico e social da cárie dentária deve ser particularizado de acordo com as características específicas de cada local.

LORETTO et al. (2000) ressaltaram que a minimização da cárie dentária na população brasileira só se dará quando esta infecção for pensada, analisada, discutida, prevenida e tratada não apenas no seu aspecto biológico, mas, sobretudo, nos seus aspectos políticos, sociais e econômicos.

A cárie é uma doença que pode ser prevenida e controlada. Ações personalizadas e coletivas de educação em saúde, principalmente quanto ao aspecto cultural do consumo de açúcares e da orientação em higiene bucal aliados a adição de flúor em água de abastecimento público e o seu uso tópico orientado na estratégia de risco populacional, são as principais medidas preventivas e de promoção de saúde bucal.

\subsubsection{DOENÇA PERIODONTAL}

Doença periodontal é um termo que inclui todas as condições patológicas de origem infecciosa do periodonto de proteção, a gengiva, e de sustentação, o cemento, ligamento periodontal e osso alveolar (CHIAPINOTTO 2000; JENKINS 1989; TINOCO e TINOCO 2000).

Estudos paleontológicos indicam que a doença periodontal ocorria no homem desde a Pré-história. Também vários documentos históricos, datados de Antes de Cristo, revelam o conhecimento da doença gengival e referem algumas formas de tratamento (CARRANZA 1979).

Primariamente, as doenças periodontais se dividem em gengivites e periodontites, sendo essas as duas formas clássicas de alteração da saúde periodontal (CARRANZA 1979; JENKINS 1989; LASCALA e MOUSSALLI 1981; TINOCO e TINOCO 2000).

Para o início da doença periodontal é necessária a presença de placa bacteriana (biofilme denta), sendo este o principal agente etiológico, o qual desencadeia uma seqüência de eventos histopatológicos à medida que se acumula e que irão variar dependendo da suscetibilidade e respostas do 
hospedeiro (CARRANZA 1979; CURY 1997; JENKINS 1989; LASCALA e MOUSSALLI 1981; LINDHE 1985; OPPERMANN e RÖSING 1997; RAMFJORD e ASH 1991; TINOCO e TINOCO 2000).

As gengivites são definidas como inflamações da gengiva e podem ser separadas em três estágios: a) lesão inicial, não visível e caracterizada por um aumento de fluxo do fluido crevicular; b) lesão precoce, que sucede a lesão inicial após aproximadamente uma semana, é visivel clinicamente, e tem como caracteristica um aumento do infiltrado inflamatório e uma modificação de brilho e textura tecidual; c) lesão estabelecida, que apresenta um grau de inflamação mais severo, com aumento de volume da área afetada e eventual formação de pseudo-bolsa, essa lesão pode persistir por meses sem progredir (GJERMO 1984; TINOCO e TINOCO 2000).

Os dois sinais iniciais de uma inflamação gengival são o aumento da produção do fluido gengival e o sangramento ao leve toque de sondagem (CARRANZA 1979). Além da precocidade do sangramento gengival como indicativo de problemas periodontais, outro fator importante é o fato de que ele facilmente é detectável após sondagem controlada, dependendo da observação visual que é objetiva, sujeita a menos erros de interpretação quando comparado com outros sinais como a alteração de cor, textura, contorno, etc. (STIZ 2001).

As periodontites se caracterizam por uma destruição do ligamento periodontal, com ou sem a perda de osso alveolar. Esse processo se evidencia por uma inflamação gengival de intensidade variável e migração apical do epitélio juncional, ocasionando a formação de uma bolsa periodontal (GJERMO 1984; TINOCO e TINOCO 2000).

Na periodontite, é importante a presença de perda de inserção aliada a sinais inflamatórios, fazendo-se mister que medidas repetidas do nivel de inserção sejam realizadas e mostrem a progressão da doença (OPPERMANN e RÖSING 1997). Destaca-se a necessidade da interferência imediata na lesão estabelecida a fim de evitar que a progressão da doença para uma lesão mais avançada. 
A gengivite é uma condição reversível, uma vez que é causada pelo acúmulo de placa supragengival, podendo ser prevenida e revertida pelo adequado controle de placa (CURY 1997; JENKIS 1989; OPPERMANN e RÖSING 1997). Caso não se implemente algum tratamento para interromper a evolução da gengivite, o tecido de sustentação pode ser atingido pela doença e então se instalar um quadro de periodontite.

Um marco histórico ao entendimento da placa bacteriana, como fator etiológico da gengivite, e da reversibilidade desta, foi o trabalho clássico sobre gengivite experimental em humanos onde de um quadro clínico de gengiva saudável, o acúmulo de placa bacteriana na superfície dental produziu gengivite em um período de sete a vinte e um dias. Com a retomada regular e eficaz de medidas de higiene bucal por parte do indivíduo, a gengiva retornou à normalidade (LÖE, THEILADE e JENSEN 1965).

Estudos longitudinais, sobre a história natural da doença periodontal, mostraram dados contrários à antiga noção de que toda a gengivite evolui para uma periodontite. Somente uma pequena porcentagem de sítios com gengivite evoluem para periodontite. No entanto, pelo fato de a inflamação ser uma condição necessária, mas não a única, para a periodontite, uma das primeiras medidas de prevenção adotadas é o diagnóstico precoce da inflamação, através da presença ou ausência de sangramento gengival (TINOCO e TINOCO 2000; OPPERMANN e RÖSING 1997).

Do ponto de vista das características etiopatogênicas, o processo saúde-doença periodontal é dinâmico e dependente da virulência das bactérias e da capacidade de defesa do organismo, sendo que o padrão de progressão está diretamente relacionado ao binômio, agressão e defesa (OPPERMANN e RÖSING 1997). A variação individual desse binômio pode explicar a diferença de suscetibilidade e severidade da doença.

Dentro da perspectiva de promoção de saúde, e tendo como base o conhecimento disponivel sobre a etiopatogenia das doenças que acometem a cavidade bucal, deve-se encarar as doenças periodontais como processos 
dinâmicos de saúde-doença, interrelacionados durante toda a vida (MARQUES 2000).

A necessidade da avaliação da prevalência da doença periodontal e do entendimento do processo saúde-doença contribuiu para a elaboração de vários índices epidemiológicos periodontais. Ressalta-se que devido a prevalência quase universal das doenças periodontais, um índice para ser realmente útil e significativo deve registrar mais do que a presença ou ausência de uma doença do periodonto; deve dar uma boa idéia da severidade da doença nos indivíduos por ela atingidos (CHAVES 1986).

Antes que os índices periodontais fossem desenvolvidos, a saúde periodontal era comumente classificada como boa, média ou má. Esse modo de classificar as condições periodontais foi usado até a década de 1950. Esses critérios subjetivos não permitiam a comparação dos resultados de diferentes estudos porque os casos de saúde boa do grupo de um examinador poderiam ser piores do que os casos de saúde má de outro examinador (LINDHE 1985).

O primeiro sistema de classificação de gengivite bem definido foi publicado por Schour e Massler, em 1947. Neste indice, denominado PMA, o número de papilas $(P)$, margens gengivais $(M)$ e áreas de gengiva inserida (A) inflamadas na face vestibular de cada dente anterior eram avaliados. Embora o índice fosse limitado a descrever gengivite apenas em torno dos dentes anteriores, ofereceu pela primeira vez a possibilidade de comparar contagens de prevalência e severidade registradas em populações diferentes (CHAVES 1986; LINDHE 1985).

Após 1950, a OMS se interessou em avaliar a doença periodontal no Oriente. Como o índice PMA não era um instrumento adequado para medir a quantidade de perda de inserção do dente, Russel, em 1956, desenvolveu o Índice Periodontal (IP), onde em cada dente da boca é aplicado um os seguintes critérios: dente com periodonto sadio (0), gengivite em torno de apenas uma parte do dente (1), gengivite circundando o dente (2), formação de bolsa (6) e perda de função devido a mobilidade excessiva (8). As 
contagens médias do IP para indivíduos e grupos populacionais eram usadas para descrever a gravidade média da doença (CHAVES 1986; LINDHE 1985).

Em 1959, Ramfjord sugeriu uma modificação do IP, criando o Índice de Doença Periodontal (IDP), onde a gengivite é pontuada, numa escala de 0 a 3 , e o aspecto destrutivo da periodontite pontuado com base no nivel de inserção, numa escala de 4 a 6 , que é medido com uma sonda periodontal. Somente seis dentes indices eram pontuados e considerados representativos para toda a boca (LINDHE 1985; RAMFJORD e ASH 1991).

A aplicação do Índice de Higiene Oral $(\mathrm{OHI})$, que se baseava em dois componentes, a extensão coronária de placa e de cálculo supragengival na superficie do dente, criado por Greene e Vermillion, em 1960, demonstrou que as diferenças raciais, geográficas e demográficas na gravidade da doença periodontal desapareciam quando os niveis da doença foram relacionados com os niveis de higiene oral (LINDHE 1985).

Depois que a relação entre doença periodontal e higiene oral foi demonstrada epidemiologicamente, indices para serem aplicados em investigações clinicas passaram a ser criados. O desenvolvimento e a apresentação do sistema de Índice Gengival, por Löe e Silness, em 1963; e do sistema de Índice de Placa, por Silness e Löe, em 1964, permitiu a realização do estudo clássico "Gengivite experimental no homem", que comprovou de forma definitiva, a relação de causa e efeito entre placa e gengivite (LINDHE 1985). Esses indices proporcionaram avaliar quantidades mais discretas de placa, pois passaram a avaliar a espessura da placa na margem gengival, bem como a extensão dos sinais de inflamação gengival associada ou não ao sangramento.

A partir da década de 70, o conhecimento adquirido sobre a etiologia e patogenia da doença periodontal trouxe uma nova inquietação: a importância de se introduzir nos estudos descritivos e analíticos, as questões referentes às necessidades de tratamento periodontal (AINAMO 1985; MARQUES 2000). 
O Sistema de Necessidade de Tratamento Periodontal (SNTP), proposto por Johansen e colaboradoes, em 1973, foi a primeira abordagem para determinar as necessidades de tratamento. No SNTP, a dentição é dividida em quadrantes; em cada quadrante o dente mais afetado é examinado. A necessidade de cirurgia periodontal, raspagem ou apenas higiene oral é determinada. De acordo com a necessidade registrada também se calcula o custo e o tempo necessário ao tratamento periodontal, além do nível de especialização que deve ter o profissional que irá tratar o indivíduo (AINAMO 1985; LINDHE 1985).

Em 1977, iniciou-se o desenvolvimento de um método internacional para avaliação das necessidades de tratamento periodontal, pela Unidade de Saúde Bucal da Organização Mundial de Saúde. Após cinco anos de trabalho, em conjunto com a Federação Dentária Internacional (FDI) e extenso trabalho de campo em inúmeros países em todo o mundo, em 1982, foi publicado por Ainamo e colaboradores o Índice Periodontal Comunitário das Necessidades de Tratamento (ICNTP ou CPITN correspondente à sigla em inglês) (LINDHE 1985).

Com a definição desse indice, gradativamente começou a ser construído um painel informativo de um quadro de comparação das doenças periodontais em nivel internacional (PINTO VG 1990).

No CPITN, a dentição é dividida em seis segmentos, para ser incluido no registro, o sextante deve ter pelo menos dois dentes em função e não indicados para extração. Uma única anotação para cada sextante é feita segundo a pior condição periodontal encontrada. Para cada código de condição periodontal registrada, a respectiva necessidade de tratamento é estabelecida. Nas crianças com menos de quinze anos de idade só devem ser considerados sangramento e presença de cálculo dental. Para maior simplificação do exame, foi criada pela OMS uma sonda periodontal especial, com uma esfera de $0,5 \mathrm{~mm}$ na ponta, e com uma área colorida em preto, situada entre 3,5 e 5,5 mm da ponta da esfera (LINDHE 1985; WHO 1987). 
No entanto, questões referentes à validade dos dados e limitações do CPITN começam a ser discutidas (PILOT et al. 1987). Sendo referido por PINTO VG (1997) que o CPITN não conseguiu definir padrões ou tendências claras da doença periodontal, em nivel internacional, devido a dificuldade ou inconsistências do índice.

Em um novo manual para a realização de levantamentos epidemiológicos, em 1997, a OMS recomenda, então, o uso do Indice Periodontal Comunitário (CPI - sigla do título original em inglês), no qual é proposta a observação da condição de saúde-doença periodontal utilizando os códigos do CPITN, mas sem indicação de necessidades de tratamento (WHO 1997).

Apesar de esforços para verificar a situação periodontal da comunidade através de índices, o melhor recurso para estudar a doença periodontal tanto em pequenos grupos quanto em grandes populações, não é contemplado nos atuais índices para investigação de massa: o nivel de inserção clínica. Sendo essa uma das maiores criticas aos índices atualmente empregados.

De 1982 a 2000, grande número de estudos epidemiológicos, localizados e de abrangência nacional, utilizando a metodologia preconizada pela OMS e o CPI têm sido realizados em diversos países. No entanto, o número de pessoas observadas em cada um dos estudos é extremamente variado, bem como as faixas etárias examinadas (MARQUES 2000).

Poucos estudos têm dirigido atenção à população de referência de escolares, especialmente à idade de doze anos. Pode ser que isto ocorra devido ao fato de que a OMS indica a idade de quinze anos para a avaliação dos indicadores de doença periodontal em adolescentes (WHO 1997).

O estudo realizado por COHEN, FISCHER e MANN (1995), em 800 indivíduos de uma comunidade de imigrantes da Etiópia, registrou aos doze anos, que o sangramento foi a condição de maior prevalência $(62,7 \%)$ e que não havia nenhum indivíduo com completa saúde periodontal.

No Brasil, GJERMO, BELLINI e MARCOS (1983) realizaram em Belo Horizonte - MG, um estudo epidemiológico em 308 adolescentes de catorze 
a dezesseis anos de idade com o objetivo de avaliar a periodontite juvenil. Os resultados demonstraram que apenas $14,0 \%$ dos sextantes não apresentavam alterações periodontais, $62,0 \%$ apresentaram cálculo e bolsas rasas e $1,0 \%$ bolsas profundas. O sangramento foi observado em $23 \%$ dos adolescentes. Os meninos apresentaram condições mais severas que as meninas.

Em 1986, o Ministério da Saúde do Brasil realizou um levantamento epidemiológico de saúde bucal de abrangência nacional e utilizou o CPITN. No grupo etário de quinze a dezenove anos, excluindo-se os edêntulos, $30,0 \%$ dos indivíduos não apresentavam doença periodontal, 20,0\% apresentavam sangramento, $42,0 \%$ cálculo, $7,0 \%$ bolsas rasas e $1,0 \%$ bolsas profundas (MINISTÉRIO DA SAÚDE DO BRASIL 1988).

FLORES-de-JACOBY et al. (1991) avaliaram as condições de universitários e militares no municipio do Rio de Janeiro - RJ. Ao todo, 1854 indivíduos, de ambos os sexos, de quinze a sessenta e sete anos de idade. No grupo etário de quinze a dezenove anos, $52,6 \%$ dos examinados apresentavam bolsas rasas como a pior condição e o número médio de sextantes saudáveis por indivíduo foi igual a 1,8.

O estudo sobre as condições periodontais de escolares de sete a dezenove anos, realizado por DINI e FOSCHINI (1997) em Araraquara - SP, verificou a condição sangramento na maioria dos examinados $(49,0 \%)$. No grupo etário de quinze a dezenove anos, somente $9,6 \%$ apresentavam todos os sextantes sadios, $49,0 \%$ sangramento e $39,8 \%$ cálculo.

No levantamento epidemiológico realizado no Estado de São Paulo, em 1998, utilizando o Indice Periodontal Comunitário, aos doze anos foram examinados 9327 escolares e registrou-se $51,7 \%$ dos indivíduos com condições saudáveis, sangramento em $30,0 \%$ e $16,8 \%$ com cálculo (USP/FSP 1998).

Em 2000, MARQUES, investigou as condições de saúde periodontal registradas para o município de São Paulo-SP no levantamento nacional em 1986 e no levantamento estadual em 1998 e observou que quanto à 
prevalência, não houve diferença significativa nas condições periodontais dos adolescentes nos dois estudos realizados e quanto à extensão, houve diferença significativa entre as proporçōes de sextantes sadios em adolescentes, sendo as melhores condições encontradas em 1998.

Em Camboriú - SC, foi realizado um estudo sobre a prevalência da doença periodontal em escolares de cinco a doze anos de idade e constatou-se elevada prevalência da doença. Sangramento gengival foi observado em $40,2 \%$ das crianças e $4,5 \%$ apresentaram cálculo dentário. Aos doze anos, a presença de sangramento gengival foi constatada em $36,9 \%$ das crianças e o cálculo dentário em 14,4\% (STIZ 2001).

\subsubsection{OCLUSOPATIAS}

Os limites que separam uma oclusão normal de uma oclusopatia nem sempre são nítidos e fáceis de serem identificados, e para que se entenda o que é uma oclusopatia, há que se definir primeiro o que é a oclusão dentária (BRESOLIN 2000).

Segundo STIZ (2001), a oclusão vem sendo considerada a "pedra angular" dos procedimentos clínicos, onde o sucesso de um grande número de intervenções no ambiente bucal, dos mais simples aos mais sofisticados e avançados tecnologicamente, depende do respeito aos seus principios. Complementou ainda que considerando o número de estruturas envolvidas na oclusão, torna-se evidente que conceituar oclusão normal e as suas alterações não é tarefa fácil. Isto porque, segundo o autor, é preciso considerar, além dos aspectos e elementos pertinentes à oclusão, a variabilidade de condições que aparecem na população e que não se caracterizam como alterações patológicas, em decorrência da capacidade adaptativa do sistema mastigatório.

O estudo da oclusão se refere não somente à descrição morfológica, penetra na natureza das variações dos componentes do sistema mastigatório e considera os efeitos das mudanças por idade, modificações funcionais e patológicas. A variação na dentição é resultado da interação de 
fatores genéticos e ambientais que afetam tanto o desenvolvimento pré-natal como a modificação pós-natal. Qualquer definição estática ou descritiva da oclusão normal deve ser evitada (GRABER 1974).

A primeira definição de oclusão normal foi proposta por Edward Hartley Angle, em 1899, quando propôs uma classificação das oclusopatias (GRABER 1974; PROFFIT 1991). Para este autor, a chave de oclusão normal é representada pelo modo de oclusão da cúspide mesiovestibular do primeiro molar permanente superior no sulco mesiovestibular do primeiro molar inferior. A classificação proposta por Angle, divide as oclusopatias em três grandes classes de acordo com as relações mesiodistais assumidas pelos primeiros molares permanentes nas suas erupções e relacionamentos:

- Classe I: a relação entre os primeiros molares está correta, com a cúspide mesiovestibular do primeiro molar superior ocluindo no sulco mesiovestibular do primeiro molar inferior. Porém, a linha de oclusão está incorreta devido a dentes malposicionados, principalmente pela desarmonia entre o volume ósseo e o volume dentário, que provoca apinhamentos, especialmente nos caninos e incisivos;

- Classe II: o molar inferior se encontra posicionado distalmente em relação ao molar superior e todo 0 arco inferior se situa posteriormente em relação à maxila. Esta classe pode ser subdividida em:

- Classe II divisão I: a relação dos molares é de classe II e os incisivos superiores se encontram alinhados, porém posicionados à frente dos incisivos inferiores, criando uma protrusão horizontal do segmento de incisivos superiores (overjet);

- Classe II divisão II: a relação dos molares é de classe Il e há um desalinhamento entre os quatro incisivos superiores, com inclinação excessiva para vestibular dos incisivos laterais e palatina dos incisivos centrais superiores; 
- Classe III: o molar inferior se encontra posicionado mesialmente em relação ao molar superior e localização anterior da mandíbula em relação ao arco superior.

Outras classificações foram propostas por Lischer, em 1912 e Simon, em 1922, mas a classificação de Angle, pela sua ampla aceitação, praticidade e objetividade tem sido a mais amplamente utilizada (ARAÚJO 1988).

Todas as classificações propostas têm adotado abordagens estáticas, desconsiderando as relações dinâmicas envolvidas no relacionamento entre as arcadas dentárias. A oclusão ideal envolve tanto características anatômicas estáticas como aspectos dinâmico-funcionais, sendo mais dependente dos últimos. Seria um engano, confundir oclusão ideal com oclusão normal. É considerada oclusão ideal, aquela que permite a realização de todas as funções fisiológicas próprias do sistema estomatognático, ao mesmo tempo em que é preservada a saúde de suas estruturas constituintes (INTERLANDI 1999).

A disposição dos dentes nos arcos dentários, a forma e o volume dos ossos maxilares e a maneira pela qual se relacionam os músculos e as articulações envolvidas, não permanecem estáticas durante toda a vida, mudando continuamente em resposta aos processos de crescimento, influências do meio ambiente, tratamentos dentários, desgastes, patologias e envelhecimento. Talvez a maior causa das oclusopatias possa ser ambiental porque a maioria é do tipo Classe 1 de Angle e não apresentam um componente esquelético (FRAZÃO 1999).

A classificação de Angle não é uma descrição de relações oclusais suficiente para estudos epidemiológicos. A sua aplicação nestes tipos de estudos produz extensas disparidades diagnósticas entre os investigadores (PROFFIT 1991).

Segundo CHAVES (1986), os indices para a avaliação de alterações oclusais devem ser vistos sob dois aspectos: o do ortodontista e o do sanitarista. O primeiro trataria de medir todos os desvios da normalidade, 
isto é, verificar numa população o número total de indivíduos cujas relações dentomaxilares se apresentam em desacordo com o conceito um tanto vago e abstrato de oclusão normal. Do ponto de vista do sanitarista, os índices baseados em critérios puramente clínicos não satisfazem. Faz falta ao sanitarista um critério importante: 0 da necessidade de tratamento sob 0 ponto de vista do ajustamento do indivíduo à vida em sociedade.

$\mathrm{Na}$ terceira edição do manual de instruções para levantamento epidemiológico básico em saúde bucal da Organização Mundial de Saúde (WHO 1987), foi apresentado um sistema de classificação para registro das oclusopatias em estudos epidemiológicos. Neste sistema são definidos códigos para registro das condições de normalidade (0), anomalia leve (1) e anomalias moderada/severa (2).

Posteriormente, na quarta edição do manual, um novo indice é proposto: o Indice Estético Dentário ( $D A l$ - sigla do título original em inglês). Esse indice proporciona a avaliação e o registro de um maior número de características relacionadas à oclusão: número de dentes anteriores ausentes, apinhamento e espaçamento nos segmentos anteriores, diastema, desalinhamento maxilar superior e inferior, sobressaliência maxilar e mandibular anterior, mordida aberta vertical anterior e relação molar anteroposterior (WHO 1997). No capítulo Material e Métodos, os critérios e códigos do DAI, bem como a fórmula de cálculo, se encontram mais detalhados.

O campo de trabalho, em relação às oclusopatias, é amplo e pouco explorado. Embora, inúmeras pesquisas tenham sido desenvolvidas nos últimos anos, do ponto de vista epidemiológico, é pequeno o número de trabalhos tanto nacionais quanto internacionais. A construção das oclusopatias, como objeto de estudo, não tem avançado em direção a uma perspectiva epidemiológica nem de saúde coletiva. Predominam desafortunadamente estudos relacionados ao diagnóstico e tratamento ortodôntico de casos clínicos e pesquisas dentro de uma delimitação temática morfológica e biomecânica (FRAZÃO 1999). 
Adicionalmente, os estudos epidemiológicos realizados, em sua grande maioria, utilizam métodos diferentes para avaliar as condições oclusais, o que torna difícil a realização de comparações dos resultados (SHAW 1997).

Todavia, independentemente desses problemas de ordem metodológica, os estudos realizados sinalizam, de um modo geral, para uma alta prevalência de oclusopatias (STIZ 2001).

GALVÃO, PEREIRA e BELLO (1994) analisaram alguns estudos epidemiológicos sobre a prevalência de oclusopatias realizados na América Latina e verificaram que na maioria desses estudos, os percentuais de alterações oclusais raramente se encontravam abaixo de $50,0 \%$, indicando uma alta prevalência da doença.

No municipio de Palhoça - SC, MASCARENHAS (1977), investigou a prevalência de oclusopatias em 414 escolares de onze a doze anos de idade. Em $46,1 \%$ dos escolares algum tipo de oclusopatia foi verificada e diferenças significativas entre os sexos não foram observadas.

No estudo realizado na liha do Governador - RJ, foi verificado que, em uma amostra de 600 crianças de cinco a sete anos de idade, $69,0 \%$ das crianças apresentavam algum tipo de oclusopatia. Ao comparar os grupos étnicos, os "pardos" apresentaram o maior percentual de oclusopatias (72,8\%) em relação aos "negros" (67,5\%) e "brancos" (66,0\%). Quanto ao tipo de oclusopatia, a classe I foi a mais prevalente, seguida da classe II e por último a classe III (SILVA CHT e ARAÚJO 1983).

SILVA FILHO, FREITAS e CAVASSAN (1990) realizaram um levantamento epidemiológico das condições oclusais, através da classificação de Angle, em 2416 crianças de sete a onze anos de escolas públicas e privadas em Bauru - SP. Registraram apenas $11,43 \%$ das crianças com oclusão normal e também que ocorria um aumento na proporção de oclusopatias e redução de oclusão normal nos escolares de nível socioeconômico mais baixo.

Em um estudo realizado em 360 escolares com doze anos de idade, na cidade de São José dos Campos - SP, foi verificado em $40,0 \%$ dos 
escolares oclusão normal, $17,5 \%$ oclusopatia do tipo "leve" e $42,5 \%$ do tipo "moderada" ou "severa". Alguns tipos de oclusopatias foram mais prevalentes no sexo feminino (MARTILDES, CASTELLANOS e ROBLES 1992).

SILVA DRAD et al. (1995) realizaram um levantamento epidemiológico em saúde bucal na cidade de Santos - SP, no qual 2397 escolares foram examinados. Nesse trabalho, $89,1 \%$ das crianças apresentaram oclusopatias com a predominância da condição "leve" em $52,4 \%$ dos casos. Entre os tipos de escola, verificou-se um maior percentual da condição "leve" nas escolas privadas e da condição "moderada/severa" nas escolas públicas. Também, quanto maior a participação do componente dente perdido no CPOD dos escolares maior a prevalência de oclusopatia.

A associação entre determinantes sociais e hábitos bucais com a oclusão dentária foi investigada, por TOMITA (1996), em 2139 pré-escolares de três a cinco anos de idade em escolas públicas e privadas na cidade de Bauru-SP. Os dados mostraram que a prevalência de oclusopatia ocorreu em torno de $50 \%$ da amostra. Não foram registradas diferenças significativas entre sexo, etnia e tipo de escola.

Em levantamento epidemiológico de saúde bucal realizado em 153 escolares, com doze anos de idade, na cidade de Osasco - SP foi verificada oclusão "normal" em 49,7\% da amostra, oclusopatia "definida" em 28,1\%, "severa" em 11,8\% e "incapacitante" em 10,5\% (FERNANDEZ et al. 1999).

FRATUCCI (2000) investigou as condições de saúde bucal de uma população indígena em São Paulo - SP e para as condições oclusais o Índice Estético Dentário foi aplicado. Aos doze anos, $85,7 \%$ das crianças apresentavam condição de oclusão "normal", nenhuma criança condição de má oclusão definida, 4,8\% má oclusão "severa" e 9,5\% "incapacitante".

STIZ (2001) realizou um levantamento sobre a prevalência da doença periodontal e de oclusopatia em 5842 escolares de cinco a doze anos de idade, em Camboriú - SC. Em relação às condições oclusais foi observada uma prevalência elevada de oclusopatias $(60,0 \%)$, bem como um aumento 
da prevalência com 0 aumento da idade. Diferenças entre os sexos não foram identificadas. Aos doze anos, em $42,8 \%$ das crianças a oclusão dentária se mostrou "normal", em $26,2 \%$ oclusopatia "leve" e em $31,0 \%$ "moderada/severa".

FRAZÃO et al. (2002), tendo como base os resultados do levantamento epidemiológico em saúde bucal de crianças de escolas públicas e privadas, de cinco a doze anos de idade realizado em São Paulo, pela Faculdade de Saúde Pública/USP, em 1996, verificou que a prevalência das oclusopatias foi alta, aumentando de $48,9 \%$ na dentição decídua para $71,3 \%$ na dentição permanente. Aos doze anos, $28,69 \%$ dos escolares apresentaram condição oclusal "normal", $31,52 \%$ oclusopatia "leve" e $39,79 \%$ oclusopatia "moderada/severa". Não foram observadas diferenças estatísticas entre os sexos, tipo de escola e grupos étnicos.

\subsubsection{FLUOROSE DENTÁRIA}

O flúor é o agente cariostático mais efetivo conhecido atualmente. Suas propriedades como agente para prevenção de cárie foram primeiramente reconhecidas, durante os anos 30 , quando Dean e colaboradores observaram que existia uma relação entre o seu conteúdo na água de abastecimento, cárie dental e fluorose endêmica (VIEGAS 1961).

Desde então, o flúor na Odontologia tem sido intensivamente estudado - que resultou na sua utilização em diversos veículos: água de abastecimento público, suplementos com flúor e o sal para uso sistêmico e produtos do tipo solução e gel, acidulados ou não; vernizes e dentifrícios para uso tópico.

O flúor é um agente quimioterapêutico, cariostático, eficiente e seguro. Após anos de uso clínico, não foi relatada sensibilidade do hospedeiro, resistência bacteriana ou superinfecção. Quando aplicado em doses terapêuticas, pode efetivamente prevenir cárie (LOESCHE 1993) e é o único método clínico extensivamente comprovado para redução de cárie dental (DUCKWORTH e MORGAN 1991). 
Até recentemente, acreditava-se que o seu maior mecanismo cariostático para prevenção da dissolução do esmalte era a sua incorporação a este tecido dental, através da utilização de métodos sistêmicos (VIEGAS 1961; LAGERLÖF e OLIVEBY 1994). Presentemente, está bem estabelecido que a atividade primária anticárie do flúor é via ação tópica, mas a atividade sistêmica também ocorre (GROENNEVELD, Van ECK e BACKER DIRKS 1990).

Atualmente, foi reconhecido que o objetivo da administração de flủor na prevenção da cárie é assegurar um certo nível deste elemento nos fluidos orais para que previna e iniba cárie dental. Ou seja, para que exerça plenamente a sua ação preventiva, ele deve estar disponivel na placa bacteriana e também na saliva, que muitas vezes serve de veículo condutor à superfície dentária (GEDDES e RøLLA 1988; RøLLA 1983; TATEVOSSIAN 1990).

Estudos têm demonstrado que o flúor nos fluidos circundando os cristais de esmalte possui um efeito potencial de reduzir a taxa de desmineralização e melhorar a taxa de remineralização. Quando presente na fase líquida durante a remineralização do esmalte desmineralizado, o flủor irá ser incorporado dentro dos cristais de esmalte e este se tornará mais resistente (LAGERLÖF e OLIVEBY 1994).

Logo, a integridade físico-química do esmalte dental é inteiramente dependente da composição e do comportamento químico dos fluidos circundantes. Um dos principais fatores que governam a estabilidade das apatitas do esmalte na saliva é a concentração do flúor em solução, o qual será incorporado à superficie de esmalte durante a exposição aos ácidos da placa nos ataques cariogênicos (LARSEN e BRUUN 1988).

Uma razão sem dúvida para o marcante efeito do flúor na cárie dental é sua habilidade em inibir não somente a desmineralização do esmalte, mas também promover a remineralização de lesões de cárie precoces, chamadas de manchas brancas (DUCKWORTH 1993) 
Quando o flúor é introduzido na cavidade bucal, irá ser distribuido na saliva e então influenciar a sua concentração no fluido da placa e no fluido do cristal do esmalte. Tanto a saliva quanto o fluido da placa são supersaturados em pH neutro com relação à hidroxiapatita e podem então apoiar a remineralização. $O$ flúor também reduz a produção ácida da placa dental (SHELLIS e DUCKWORTH 1994).

Após aplicação tópica de flúor, o fluoreto de cálcio $\left(\mathrm{CaF}_{2}\right)$ é formado nos tecidos dentais duros, permanecendo relativamente estável nas superficies dentárias e persistindo por semanas. Este composto protege a superficie de esmalte diretamente, fornecendo ions flúor $\left(F^{-}\right)$livres para subsequente incorporação na hidroxiapatita e formação de fluorapatita. $O$ fluoreto de cálcio serve como um reservatório de íons flúor e também de ions cálcio, os quais são mobilizados quando o pH cai para 5 ou menos (RøLLA 1988). Isto ocorre, durante os ciclos de $\mathrm{pH}$ na placa e não no momento da aplicação tópica (ØGAARD, SEPPÄ e RøLLA 1994).

Quando se utiliza um método sistêmico, após a ingestão de qualquer quantidade de flúor, imediatamente uma parte reage quimicamente com as estruturas dentárias, a maior parte é deglutida e pequena quantidade é absorvida diretamente à corrente sanguínea através da mucosa bucal. Durante o seu trajeto no trato gastrointestinal outra porção do flúor atravessa membranas celulares e alcança a corrente sanguínea de onde se acumula nos ossos. Finalmente o restante é excretado, principalmente pelos rins, fezes e suor (WHITFORD 1990). Uma parte do flúor absorvido retorna à cavidade bucal através da reciclagem pela saliva e fluido gengival. Nos períodos entre as ingestōes, o flúor é mantido constante na saliva metabolicamente (CURY 1989).

O flúor também pode ser tóxico, é só uma questão de dose, que é o parâmetro de diferenciação entre remédio e veneno. A toxicidade do flúor pode ser dividida em aguda e crônica. A aguda está relacionada à ingestão de uma quantidade grande de flúor de uma única vez e a crônica à ingestão 
de pequena quantidade durante um período de tempo prolongado (CURY 1989).

As manifestações da intoxicação crônica são a fluorose esquelética e a fluorose dentária. A fluorose esquelética será observada com a ingestão de flúor acima de 5,6 ppm(partes por milhão)/dia, apresentando-se como uma osteoclerose generalizada e caracterizando-se radiograficamente por radiopacidade óssea (CURY 1989).

O primeiro sintoma de ingestão de flúor acima do limite adequado por longos periodos é o aparecimento de formas leves de fluorose dentária, ou seja, de manchas esbranquiçadas em forma de linhas seguindo as periquimáceas do esmalte (SILVA MF de A 1997).

A ocorrência da fluorose dentária está vinculada à história do ser humano na terra. Dentes com manchas escuras e desfigurados foram encontrados em crânios com milhares de anos de idade (FEJERSKOV et al. 1994).

A fluorose dentária é um distúrbio induzido pelo flúor na formação dentária, que resulta em um esmalte hipomineralizado com porosidade aumentada. É causada pelo excessivo consumo de flúor, mas, somente durante o período de desenvolvimento dentário (BUZALAF, CURY e WHITFORD 2001).

As características clínicas da fluorose são definidas por uma gama de mudanças no esmalte e há dois aspectos importantes a serem considerados que são a bilateralidade e a simetria, pois são afetados os dentes que se formaram no mesmo período. As formas mais suaves podem ser observadas através de estrias ou linhas brancas horizontais, finas e opacas, cruzando a superfície do esmalte. Em alguns casos, as pontas de cúspides dos dentes posteriores, bordas incisais de dentes anteriores e cristais marginais podem apresentar manchas brancas opacas que são denominadas "coberturas de neve". Em formas mais severas, regiões amareladas ou castanhas podem ser visualizadas (FEJERSKOV et al. 1994). 
Os mecanismos envolvidos nos desenvolvimento da fluorose dentária não estão conclusivamente determinados. Anteriormente acreditava-se que o excessivo consumo de flúor interferia na função dos ameloblastos, talvez inibindo a secreção de proteínas ou alterando a composição da matriz protéica do esmalte. Atualmente, parece ser improvável que isto ocorra devido a várias razões, incluindo o fato de que o risco de fluorose dentária é menor durante a fase secretória de desenvolvimento do esmalte. Estudos clínicos têm demonstrado que o periodo mais crítico para o desenvolvimento de fluorose é durante o período pós-secretório ou fase inicial de maturação do desenvolvimento dentário (BUZALAF, CURY e WHITFORD 2001).

A fluorose é menos prevalente e menos aparente na dentição decídua que na dentição permanente. Uma vez que os diferentes dentes permanentes se desenvolvem em diferentes periodos, o período crítico para esta dentição se estende dos onze meses aos sete anos de idade. É relatada a dosagem limite de 0,1 miligrama $(\mathrm{mg})$ de flúor por quilo corpóreo diária como nivel limite de exposição para a ocorrência de fluorose, embora tenha sido encontrada fluorose em consumo diário de doses menores que 0,03 mg (BUZALAF, CURY e WHITFORD 2001; ISHII e SUCKLING 1991).

Fatores que podem aumentar a suscetibilidade dos indivíduos para a fluorose dentária são altitude, insuficiência renal e precário estado nutricional (BUZALAF, CURY e WHITFORD 2001; FEJERSKOV et al. 1994).

A prevalência e a severidade de fluorose dentária têm aumentado em vários locais no mundo, desde 1945, independente de haver ou não a fluoretação da água de abastecimento público. A porção de fluorose devida à fluoretação da água é agora menor que $40 \%$ enquanto que atribui-se a outras fontes de flúor cerca de 60\% (LEWIS e BANTING 1994).

Para a mensuração da fluorose dentária, vários sistemas de classificação são descritos na literatura o que dificulta a comparabilidade dos estudos (CANGUSSU et al. 2002; FORNI 2000). Os mais utilizados são o indice de Dean e o índice de Thylstrup e Fejerkov.

O índice de Thylstrup e Fejerkov classifica a fluorose dentária em nove graus de severidade. Até a categoria "4" há uma escala ordinal do 
comprometimento do esmalte em relação à opacidade e a partir da categoria "5" há uma escala ordinal das perdas de esmalte. Para sua utilização, são recomendadas a profilaxia prévia e a secagem das superfícies dentárias antes do exame. Costuma ser mais indicado para populações com altas exposições a fluoretos ou alta prevalência da doença (FEJERKOV et al. 1994).

O índice de Dean é baseado em variações no aspecto do esmalte, desde a categoria normal até a forma severa, abrangendo seis categorias. É o índice mais utlizado, não requer secagem e é recomendado pela Organização Mundial de Saúde (WHO 1987, 1997). Esse índice está apresentado em detalhes no capítulo Material e Métodos.

Com base na relação quantitativa entre a concentração de flúor na água e o incremento nos graus de severidade da fluorose dentária, Dean atribuiu pesos a cada grau de fluorose: normal $(0)$, questionável $(0,5)$, muito leve (1), leve (2), moderada (3) e severa (4). Fazendo o somatório das frequências de cada categoria na população mutiplicadas pelo peso atribuído e divididas pelo número total de indivíduos examinados pode ser calculado o Indice de Fluorose Dentária da Comunidade (CHAVES 1986).

A fluorose dentária é altamente dependente da dose, duração e tempo de exposição ao flúor e é melhor correlacionada com a exposição total cumulativa ao flúor no periodo de desenvolvimento da dentição (Den BESTEN 1999).

VILLA et al. (1998) realizaram um estudo de prevalência de fluorose em San Felipe, no Chile, cidade com nível ótimo de flúor na água. O exame de 136 residentes, classificados segundo a idade que possuiam quando a água começou a ser fluoretada em 1986, demonstrou a ocorrência de fluorose muito leve a moderada em incisivos centrais superiores, a qual foi fortemente associada com a idade dos indivíduos e com o tempo de amamentação no grupo que nasceu no mesmo ano que começou a fluoretação. 
Estudos realizados em áreas com e sem água fluoretada têm identificado quatro principais fatores de risco à fluorose: uso de água fluoretada, suplementos com flúor, dentifrícios com flúor e fórmulas infantis, antes da idade de sete anos (BUZALAF, CURY e WHITFORD 2001; RIORDAN e BANKS 1991).

EI-NADEEF e HONKALA (1998) avaliaram a relação entre a presença de flúor na água em duas cidades na Nigéria, com concentrações de zero a 0,4 ppmF e a prevalência de fluorose. Uma amostra de 203 escolares de doze a quinze anos de idade, residentes permanentes, foi examinada. Os resultados demonstraram que $51,0 \%$ das crianças apresentaram fluorose, $41,0 \%$ do tipo muito leve, $7,0 \%$ do tipo leve e $3,0 \%$ do tipo moderado e severo. Concluíram que outros fatores que não os níveis de flúor na água contribuiram para a severidade da fluorose dentária.

CURY (1989) relatou que quando a concentração de flúor na água é mantida dentro dos valores recomendados haverá fluorose dentária na população em um nível considerado aceitável (10 a 15\%). À medida que a concentração de flúor é superior ao recomendado, aumenta a severidade da fluorose alcançando niveis que afetam tanto a estética como a função dos dentes.

A redução de cárie, como efeito da fluoretação da água de abastecimento, está em torno de 50 a 60\% (MARTILDES, CRISÓSTOMO e OLIVEIRA 1995; SILVA MF de A 1997; VIEGAS e VIEGAS 1974, 1985). Os valores para adição de flúor à água de abastecimento público são dependentes da temperatura ambiente, pois se baseiam no volume de água ingerida diariamente.

No Brasil, é adotada a fluoretação das águas com experiências bem sucedidas desde 1953. A Lei Federal $n^{\circ}$ 6.050, de 24 de maio de 1974 , dispõe sobre a obrigatoriedade da fluoretação da água de abastecimento em locais quando existir estação de tratamento. O Decreto $n^{\circ}$ 76.872, de 22 de dezembro de 1975 , estabelece os critérios e teores para a fluoretação. Para 
a maior parte do território nacional, o limite ótimo está entre 0,6 e 0,8 ppmF. (BUENDIA 1983; NARVAI 2000; NARVAl et al. 2002).

É importante referir também que o Decreto $n^{0} 76.872$ deixa claros alguns requisitos mínimos em relação ao abastecimento da água fluoretada, dentre eles destaca-se o caráter regular, sem interrupção da medida e o controle rotineiro da qualidade da água distribuída com o monitoramento dos teores de flúor. No entanto, nem sempre a legislação tem sido cumprida.

A vigilância da fluoretação das águas de abastecimento público, com base no princípio do heterocontrole, é requerida para que a medida a população não seja exposta a teores de flúor inadequados (SILVA CAL, ALVES e FREITAS 1998; CANGUSSU et al. 2002; NARVAI 2000).

A utilização de suplementos com flúor tem sido alvo de várias discussões em torno de que essa não seja mais uma medida necessária em saúde pública. SILVA MF de A (1997) ressaltou que a suplementação pode ser utilizada nas seguintes situações, quando observadas em conjunto e não isoladamente: em áreas não fluoretadas, quando as mães forem educadas a utilizar pequenas quantidades de pasta dental fluoretada, quando por motivos econômicos ou de saúde não houver o acesso à pasta dental fluoretada e em programas extremamente controlados. Para o cálculo da dose, o autor sugere a utilização de esquemas de baseados na proporção $\mathrm{mgF} / \mathrm{Kg}$ de peso.

Portanto, suplementação com flúor não deve ser utilizado concomitante a outros métodos sistêmicos para não favorecer a um excesso de dosagem constituindo-se num potencial fator de risco à fluorose (BUZALAF, CURY e WHITFORD 2001; CANGUSSU et al. 2002).

A constatação de que tem aumentado o nivel de fluorose nas populações, inclusive em regiōes onde a água não é fluoretada, fez com que trabalhos estejam sendo direcionados a um novo questionamento: o ajuste da fluoretação da água versus o uso de métodos tópicos (BELTRÁNAGUILAR, GRIFFIN e LOCKWOOD 2002)0. 
RIPA (1991) fez uma revisão de estudos sobre a utilização de métodos tópicos de flúor em áreas com redução da prevalência da cárie dentária e aumento da prevalência de fluorose dentária. Destacou que crianças menores que seis anos de idade ingerem cerca de 14 a $60 \%$ da quantidade de dentifrícios utilizada, concluindo que o aumento da prevalência de fluorose dentária foi mais observado nas regiões com teores deficientes de flúor na água.

A ingestão de grande parte dos dentifrícios fluoretados durante o seu uso, por crianças pequenas tem sido relatada na literatura (LEVY 1993; SILVA MF de A 1997).

Assim, são recomendadas medidas para limitar a ingestão excessiva de flúor conseqüente à somatória de utilização de métodos sistêmicos e a ingestão de dentifrícios: redução da concentração de flúor em pastas infantis, utilização de pequenas quantidades de pasta por escovação, não mais que 0,25 gramas ("pequeno grão de ervilha") e alerta aos pais para o risco de deglutição pelas crianças (BUZALAF, CURY e WHITFORD 2001; CANGUSSU et al. 2002; LEVY 1993; SILVA MF de A 1997, 2000).

Alguns alimentos e bebidas manufaturados podem ser importantes contribuintes para a ingestão diária total de flúor. Peixes, mariscos, frango, chás, bebidas (água mineral, refrigerantes), fórmulas infantis e leite quando processados em regiões com abastecimento de água fluoretada podem estar associados ao desenvolvimento de fluorose dentária (BUZALAF, CURY e WHITFORD 2001; CANGUSSU et al. 2002; SILVA MF de A 1997).

CLARK et al. (1994) avaliaram a influência da exposição a vários métodos de flúor e na prevalência de fluorose dentária e verificaram que o uso de fórmula infantil e o nivel educacional dos pais foram estatisticamente associados à ocorrência de fluorose nos graus dois a seis.

No Brasil, Duarte (2001) citado por BUZALAF, CURY e WHITFORD (2001), registrou em alguns cereais e leites achocolatados concentrações de flúor bastante altas (de 1,2 ppmF, 2,4 ppmF e 6,2 ppmF). Se um destes produtos for consumido apenas uma vez ao dia por uma criança de dois 
anos de idade, ocorrerá um aumento de mais de $25 \%$ na dose limite diária de ingestão de flúor(0,1 mgF/Kg corpóreo/diária).

Assim, produtos manufaturados devem informar em seus rótulos os conteúdos de flúor e ações de vigilância para a fiscalização e controle desses teores devem ser realizadas (CANGUSSU et al. 2002).

Alguns trabalhos nacionais sobre a prevalência e a severidade da fluorose dentária serão relatados a seguir.

Em Pereira Barreto - SP, UCHÓA e SALIBA (1970) examinaram 442 escolares de sete a quinze anos de idade, residentes no município, após dez anos de início do funcionamento do sistema de abastecimento de água através de cinco poços artesianos. A concentração de flúor nas amostras de água foi de 2,2 a 17,5 ppmF e a prevalência de fluorose: $24,8 \%$ normal; $9,1 \%$ questionável; $30,8 \%$ muito leve; $14,0 \%$ leve; $8,4 \%$ moderada e $12,9 \%$ severa. Os autores sugeriram a correção das concentrações de flúor na água.

CAPELLA et al. (1989) desenvolveram um levantamento epidemiológico de fluorose dentária em 338 escolares de três a dez anos de idade, residentes no Distrito de Cocal/Urussanga - SC, que utilizavam indiscriminadamente água poluída pelo excesso de flúor e/ou água de poços caseiros com concentrações de 1,2 a 5,6 ppmF. Apenas $2,4 \%$ das crianças não apresentaram fluorose, $87,0 \%$ apresentaram fluorose nos graus 3 e 4 do índice de Dean. Em relação ao sexo não houve diferença estatística.

No levantamento epidemiológico em saúde bucal da cidade de Santos - SP, SILVA DRAD et al. (1995), examinaram 2397 escolares, de cinco a doze anos de idade, e verificaram a prevalência de fluorose dentária de $30,2 \%$, sendo $19,3 \%$ na forma muito leve, $8,6 \%$ leve, $2,0 \%$ moderada e $0,3 \%$ severa. As diferenças entre os tipos de escola foram avaliadas e não apresentaram diferenças estatísticas.

HEINTZE, BASTOS e BASTOS (1998) investigaram a prevalência de fluorose em três municípios brasileiros, com diferentes concentrações de flúor na água, Garça (0,90 ppmF), Bauru (0,64 ppmF) e Itápolis (0,02 ppmF). 
Uma amostra de 985 individuos de 5 a 24 anos de idade foi examinada. Os percentuais de prevalência observados, para as cidades, foram respectivamente $13,3 \%, 6,8 \%$ e $1,7 \%$ nas formas mais brandas ( 1 e 2 ), segundo o índice de Thylstrup. Os autores ressaltaram a necessidade de vigilância da fluoretação da água de abastecimento.

CARDOSO (1999) realizou um levantamento epidemiológico de fluorose dentária em dois municipios do Estado da Bahia, Alagoinhas (com fluoretação a mais de 20 anos) e Pojuca (sem fluoretação). Foram examinadas 454 crianças de doze anos de idade. Foi observada variação significativa na ocorrência de fluorose entre os dois municipios, com a prevalência igual a $55,4 \%$ em Alagoinhas e 43,5\% em Pojuca, sendo que o tipo leve e muito leve tiveram prevalência, respectivamente, de $24,2 \%$ e $22,1 \%$ na primeira cidade e $20,6 \%$ e $18,8 \%$ na segunda.

FORNI (2000) descreveu levantamentos epidemiológicos, de fluorose dentária, realizados em escolares, os quais foram realizados em 10 municípios do Estado de São Paulo - SP. Para cada idade e para o intervalo de cinco a doze anos de idade foram calculados o indice de Fluorose Comunitária e a proporção de escolares com ausência de fluorose. À medida que aumentou a idade diminuiu a proporção de casos ausentes de fluorose em todos os municipios. Rio Grande da Serra e Ribeirão Pires apresentaram as maiores prevalências, em seguida São Caetano do Sul, São Vicente, Santos e Mauá. No município de São Paulo, dois estudos eram disponiveis, havendo diferença estatística entre os dois estudos, com maior prevalência no ano de 1998. Para a variável sexo, foi observada diferença significativa em Diadema e São Paulo, com maiores prevalências nos sexos feminino e masculino respectivamente. Em relação aos grupos étnicos, diferenças estatisticamente significativas foram observadas em Santos, São Caetano do Sul e São Paulo, com indicadores mais elevados para não brancos (amarelos, negros e pardos).

FERNANDEZ et al. (1999) realizaram levantamento epidemiológico em saúde bucal em Osasco - SP, duzentos escolares foram examinados e 
observou-se a prevalência de fluorose em $48,3 \%$ das crianças, sendo $44,4 \%$ nas formas leve/muito leve e 3,9\% na forma moderada.

Um estudo sobre a prevalência da fluorose dentária em pré-escolares e escolares participantes do programa de promoção de saúde bucal da Prefeitura do Município de Osasco - SP foi realizado por MASSARO (2000). Exames foram realizados em 4.046 crianças de cinco a doze anos de idade. Essa população apresentou $19,3 \%$ de casos de fluorose dentária que variaram entre os graus muito leve, leve $(19,0 \%)$ e moderada $(0,3 \%)$. Aos doze anos as seguintes prevalências de graus de fluorose dentária foram observadas: $82,2 \%$ ausente, $9,6 \%$ questionável, $6,8 \%$ muito leve e $1,4 \%$ leve. Concluiu-se a necessidade de heterocontrole dos teores de flúor nas águas de abastecimento público e a racionalização do uso do flúor tópico no programa.

PATIÑO (2001) investigou a prevalência de fluorose dentária em 1.847 escolares de cinco a doze anos de idade. Os resultados mostraram uma prevalência de $11,2 \%$ de fluorose, sem diferenças entre os sexos e distribuída da seguinte forma: $8,2 \%$ muito leve, $2,1 \%$ leve, $0,8 \%$ moderada $e$ $0,1 \%$ severa.

PEREIRA et al. (2001) realizaram comparações entre os dados de prevalência e severidade da cárie e fluorose dentária em duas cidades do Estado de São Paulo (Iracemápolis e Piracicaba) com diferentes concentrações de flúor em suas águas de abastecimento público $(0,2$ e 0,7 ppmF respectivamente. Escolares de onze a treze anos foram examinados em levantamentos nos anos de 1991, 1995 e 1997. Verificou-se um aumento da prevalência em 51,9\% em Piracicaba e 40,5\% em Iracemápolis. Nenhum caso severo foi verificado, no entanto, os autores indicaram a realização de estudos longitudinais e a vigilância da fluoretação.

Em Marinópolis - SP, BRANDÃO et al. (2002) examinaram todos os escolares, residentes no município desde o nascimento (320), e registraram a prevalência de fluorose em $17,2 \%$ dos escolares, sendo $10,0 \%$ na forma muito leve, $5,3 \%$ na forma leve, $1,3 \%$ na moderada e $0,6 \%$ na severa. 
Concluirram que a fluorose na população estudada não se constituiu um problema de amplas dimensões, no entanto, novos estudos deveriam ser realizados para a identificação das causas da ocorrência de fluorose moderada e severa.

Uma revisão crítica sobre os estudos epidemiológicos, publicados no país, sobre a prevalência e a severidade da fluorose dentária e dos seus possíveis fatores de risco foi realizada por CANGUSSU et al. (2002). Os resultados evidenciaram a ocorrência de freqüências mais altas que as esperadas, embora com poucos casos de maior severidade. Concluíram que a fluorose dentária se constitui em problema relevante para a saúde bucal coletiva e que são necessárias medidas de vigilância à saúde bucal.

Assim, as medidas de prevenção e controle melhor aplicadas à fluorose dentária são o monitoramento da ingestão total diária de flúor, a vigilância sanitária para a permanente avaliação dos niveis ótimos de flúor, a vigilância epidemiológica e a educação em saúde para a população em relação a superexposição a produtos fluoretados.

\subsection{METAS EM SAÚDE BUCAL}

A Organização Mundial da Saúde e a Federação Dentária Internacional - FDI apresentaram em uma Assembléia Mundial, realizada no Rio de Janeiro - RJ, em 1981, metas em saúde bucal a serem alcançadas no ano 2000 (FDI 1982). Essas metas foram embasadas na proposta "Saúde para todos no ano 2000" da OMS em 1979 e objetivavam permitir comparações internacionais dos indicadores de saúde bucal.

As metas propostas enfocaram principalmente a cárie dentária e o edentulismo, segundo grupos etários índices.

As seguintes metas foram propostas:

1. $50,0 \%$ das crianças aos cinco-seis anos livres de cárie;

2. $\quad$ CPOD médio aos doze anos de idade $\leq 3$; 
3. $85,0 \%$ da população de dezoito anos de idade deve ter todos os dentes;

4. $50,0 \%$ de redução dos níveis de edentulismo observados no grupo etário de 35-44 anos;

5. $25,0 \%$ de redução dos niveis de edentulismo observados na idade de sessenta e cinco anos;

6. estabelecimento de um sistema de monitoramento das condições de saúde.

A expectativa era de que cada país utilizasse as metas como um guia e formulasse as suas próprias metas nacionais ou locais de acordo com a sua realidade e recursos. Para tanto, foi ressaltada a importância da realização de levantamento epidemiológicos em saúde bucal em grupos populacionais, a cada cinco anos para o acompanhamento das tendências em direção às metas (FDI 1982).

A partir da recomendação do uso do CPITN para levantamentos epidemiológicos, passou-se a discutir quais metas que poderiam ser formuladas a partir do percentual de indivíduos ou sextantes que seria considerado aceitável para cada um dos grupos etários (MARQUES 2000).

Barmes e Leous (1986) citado por MARQUES (2000), com base nos resultados de exame periodontal em dezesseis países de todos os continentes, sugeriram como meta global para a saúde periodontal, aos doze anos de idade, não menos que três sextantes saudáveis, podendo chegar a 3,5 no ano 2000 .

Desde que as metas OMS-FDI/2000 foram elaboradas várias críticas, entre elas de que não faz qualquer sentido propor metas globais, dadas as caracteristicas dessa área e também de que se as metas são globais deveriam corresponder a um planejamento global. Apesar das criticas, onde quer que tenha havido ações bem planejadas de odontologia em saúde pública, as metas foram utilizadas como referência para organizar e avaliar as ações desenvolvidas (NARVAI 2002). 
Neste mesmo artigo, NARVAI (2002) p.1 relatou que, em 1993, no "4은 Congresso Mundial de Odontologia Preventiva", realizado na Suécia, a OMS propôs as metas para o ano 2010 com relação à saúde bucal:

"90\% de pessoas sem cárie na idade de cinco a seis anos; CPOD menos que 1 aos doze anos de idade; aos quinze anos de idade, não mais que um sextante com CPITN 1 ou 2; não haver perda dental, aos dezoito anos de idade, devido à cárie ou doença periodontal; na idade de 35-44 anos não mais que $2 \%$ de desdentados; $96 \%$ de pessoas com no mínimo vinte dentes funcionais; não mais que 0,25 sextante com CPITN de 4; não mais que $5 \%$ de desdentados e não mais que 0,50 sextante com CPITN de 4 na idade de 65 a 74 anos".

Mediante as críticas que foram feitas sobre o estabelecimento de metas globais, a OMS não recebeu o apoio da FDI, não oficializando as metas para 2010. No entanto, ressalta-se que reconhecido ou não o conjunto de metas divulgado em 1993, a sua utilização pode ser útil aos administradores locais na tarefa de estabelecer objetivos, mediante a análise da situação, tecnologias e recursos disponiveis (NARVAI 2002).

Portanto, a utilização das metas globais como norteadoras é de extrema valia para o planejamento local ou regional de objetivos em saúde bucal. Esse planejamento também requer a análise da situação de saúde bucal da população e a criação de um banco de dados para monitoramento dos indicadores de saúde bucal.

O presente trabalho, através dos instrumentos da epidemiologia descritiva, estima as condições de saúde bucal referentes à cárie dentária, doença periodontal, oclusopatias e fluorose dentária de escolares com doze anos de idade de Feira de Santana - BA, dentro do contexto da promoção da saúde, visando contribuir à elaboração de metas locais de saúde bucal direcionadas a esse grupo. 


\section{OBJETIVOS}

A proposição geral deste estudo foi analisar a saúde bucal de escolares com doze anos de idade na área urbana do município de Feira de Santana - Bahia, de modo a contribuir na elaboração local das atividades de saúde bucal, através dos seguintes objetivos:

3.1. estimar a prevalência da cárie dental em escolares de doze anos de idade na área urbana da cidade de Feira de Santana por tipo de escola;

3.2. estimar as condições periodontais dos escolares de doze anos de idade na área urbana da cidade de Feira de Santana por tipo de escola;

3.3. estimar a prevalência e severidade da fluorose dentária em escolares de doze anos de idade na área urbana da cidade de Feira de Santana por tipo de escola;

3.4. estimar as anomalias dentofaciais e a condição oclusal dos escolares de doze anos de idade na área urbana da cidade de Feira de Santana por tipo de escola;

3.5. relatar as ações de saúde bucal, realizadas no município de Feira de Santana, em particular as direcionadas aos escolares. 


\section{MATERIAL E MÉTODOS}

\subsection{Tipo de estudo}

A pesquisa se caracterizou como um estudo epidemiológico descritivo com a identificação das condições de saúde bucal da população de referência e das ações de atenção em saúde bucal voltadas a esta população.

\subsection{População de referência}

A rede de ensino fundamental no município de Feira de Santana, em 2000, quando este trabalho foi planejado, era composta por 449 escolas, sendo 293 públicas e 156 particulares. Na área urbana estavam situadas 312 escolas, destas 81 eram estaduais, 75 municipais e 156 particulares. Deste universo, 226 escolas possuíam alunos com doze anos de idade.

A população total de escolares no municipio, em 2000, era de 180.704 indivíduos, representando o ensino fundamental 131.406, o equivalente a $72,72 \%$ do total de matrículas. A população de crianças com doze anos de idade, em todas as escolas urbanas, de ambos os sexos, era de 8.739 escolares, distribuídas $5.028(57,6 \%)$ nas instituições estaduais, 2.450 $(28,0 \%)$ nas municipais e $1.261(14,4 \%)$ nas particulares.

Os dados sobre a população de referência estão apresentados nas Tabelas 1,2 e 3 .

Tabela 1 - Distribuição do número de escolas e número de matrículas por dependência administrativa. Feira de Santana - BA, 2000.

\begin{tabular}{lcc}
\hline Dependência administrativa & Escolas & Matrículas \\
\hline Federal & - & - \\
Estadual & 96 & 97.686 \\
Municipal & 227 & 58.329 \\
Particular & 194 & 24.689 \\
\hline Total & 517 & 180.704 \\
\hline
\end{tabular}

Fonte: Secretaria de Educação e Cultura (SEC), MEC/INEP. Censo Escolar 2000 
Tabela 2 - Distribuição do número de escolas do ensino fundamental, número de escolas com alunos de doze anos e de escolares com doze anos de idade segundo dependência administrativa e localização da escola. Feira de Santana - BA, 2000.

\begin{tabular}{llrcc}
\hline $\begin{array}{l}\text { Dependência administrativa e } \\
\text { localizaçäo }\end{array}$ & Escolas & $\begin{array}{l}\text { Escolas c/ alunos cl } \\
\text { doze anos de idade }\end{array}$ & $\begin{array}{l}\text { Escolares com } \\
\text { doze anos de idade }\end{array}$ \\
\hline Estadual & Rural & 11 & 11 & 290 \\
& Urbana & 81 & 77 & $5028^{\star *}$ \\
Municipal & Rural & 126 & 118 & 1329 \\
& Urbana & 75 & $66^{\star}$ & $2450^{\star \star}$ \\
Particular & Urbana & 156 & $83^{*}$ & $1261^{\star *}$ \\
\hline Total & & 449 & 353 & 1358 \\
\hline
\end{tabular}

Fonte: Secretaria de Educação e Cultura (SEC), MEC/INEP. Censo Escolar 2000

* Total de escolas urbanas com escolares de doze anos de idade: 226.

** Total de escolares com doze anos na área urbana: 8.739 .

Tabela 3 - Distribuição do número de escolares do ensino fundamental segundo sexo, dependência administrativa e localização da escola. Feira de Santana - BA, 2000.

\begin{tabular}{llrrr}
\hline \multirow{2}{*}{ Dependência administrativa e localização } & \multicolumn{2}{c}{ Sexo } & Total \\
\cline { 3 - 4 } & & Feminino & Masculino & \\
\hline Estadual & Rural & 2.057 & 1.859 & 3.916 \\
& Urbana & 33.657 & 31.236 & 64.893 \\
Municipal & Rural & 7.061 & 8.029 & 15.090 \\
& Urbana & 16.057 & 17.536 & 33.593 \\
Particular & Urbana & 7.004 & 6.910 & 13.914 \\
\hline Total & & 65.836 & $\mathbf{6 5 . 5 7 0}$ & $131.406^{\star}$ \\
\hline \hline
\end{tabular}

Fonte: Secretaria de Educação e Cultura (SEC), MEC/INEP. Censo Escolar 2000

* Valor que representa $72,72 \%$ do total de matrículas no município.

\subsection{Amostra}

A amostra foi retirada da população de escolares com doze anos de idade, sendo que, os elementos amostrais foram sorteados a partir da lista de escolas estaduais, municipais e particulares da área urbana de Feira de Santana, fornecida pela Diretora Regional de Educação com os dados do Censo Escolar - ano 2000.

\subsubsection{Critérios para composição da amostra}

- Somente foram incluídas as escolas que possuíam alunos com doze anos de idade, comprovada pelo registro escolar, de ambos os sexos. Esta idade foi selecionada por ser a escolhida para monitorização 
global para cárie nas comparações internacionais e para acompanhamento das tendências da doença (WHO 1997). Além de que neste momento, todos os dentes permanentes, exceto os terceiros molares, se encontram erupcionados.

- O tamanho da amostra foi calculado segundo PINTO VG (1996), para estudos de valor médio do CPOD (Dentes Cariados, Perdidos e Obturados) com precisão e confiança estabelecidas.

Como, em Feira de Santana, não se conhecia o CPOD médio da população de referência e não existia tempo hábil para a realização de um levantamento exploratório, segundo o que é preconizado para o cálculo amostral pela Organização Mundial de Saúde - OMS (WHO 1997), foi adotado como referência, o CPOD médio verificado por CASTRO (1998) em 55 escolares de doze anos neste município.

Portanto, adotando-se o CPOD médio $(\mathrm{x})$ igual a 1,91, com desvio padrão (s) igual a 1,72, um nível de significância de $\alpha=0,05$. Procedendo-se o arredondamento dos valores da média e do desvio padrão para 2,0, o tamanho da amostra requerido para o trabalho foi de 384 crianças em cada tipo de escola, estadual, municipal, e particular (Anexo 1).

Ao tamanho da amostra estimado em 384 foi acrescido um percentual de $20 \%$, a fim de dar conta de possiveis perdas durante a pesquisa de campo, o que resultou numa amostra de 461 crianças em cada tipo de escola perfazendo um total de 1.383 escolares.

- A seleção da amostra foi feita em 2 estágios. No primeiro estágio, a fim de se selecionarem as escolas, construiu-se um cadastro destas e dentro de cada grupo estabelecido (estadual, municipal e particular) ordenaram-se aquelas segundo o tamanho, ou seja, da escola com menor número de alunos para a escola com o maior número.

Após construida esta listagem, calculou-se segundo o princípio de amostra por conglomerados o número de escolas que seriam incluídas no trabalho, o que resultou em 26. A este valor acrescentou-se uma 
margem de segurança de $20 \%$, sendo então o número de escolas aumentado para 33 .

Em seguida, distribuiu-se proporcionalmente o valor 33, na representação percentual de cada tipo de escola. Desta forma, foram sorteadas sistematicamente dezessete escolas estaduais na listagem construída; e assim sucessivamente, dez municipais e seis particulares. No entanto, após o sorteio das escolas e contato com as mesmas, ao listarem-se as crianças matriculadas segundo a data de nascimento verificou-se, ao ser feita a exclusão das crianças que não apresentavam a idade estabelecida, que faltavam crianças para completar o tamanho amostral estimado. Assim, foi realizado um segundo sorteio de escolas, com os mesmos critérios do primeiro. Neste novo sorteio foram então acrescidas mais duas escolas estaduais, seis municipais e treze particulares.

- No segundo estágio, para definição dos alunos participantes, a partir da relação das turmas com alunos de doze anos matriculados, construiuse o rol destes alunos segundo cada grupo de escolas e na mesma ordem das escolas no cadastro inicial do sorteio das escolas. Da listagem geral construída para cada tipo de escola dividiu-se o número total de alunos existentes pelo número amostral desejado $(n=461)$ o que resultou no expansor para sorteio sistemático das crianças.

\subsection{Variáveis de Estudo}

- Cárie dentária: medida através do Índice de ataque de cárie CPOD (Cariados, Perdidos, Obturados - Dentes) e das Necessidades de tratamento (WHO 1997).

- Condição periodontal: avaliada através do Índice Periodontal Comunitário - CPI (sigla do título original em inglês: Community Periodontal Index) (WHO 1997). 
- Anomalias dentofaciais e condição oclusal: mensuradas a partir do Índice Estético Dentário - DAl (sigla do titulo original em inglês: Dental Aesthetic Index) (WHO 1997).

- Fluorose dentária: através da utilização do Índice de Dean (WHO 1997).

- Tipo de escola: estadual, municipal e particular.

\subsubsection{COVARIÁVEIS}

- Sexo: feminino e masculino.

- Etnia: categorizada através dos critérios preconizados pela Fundação Instituto Brasileiro de Geografia e Estatística (IBGE), utilizados no Censo de 1991.

- Escolaridade dos pais, renda familiar e acesso ao atendimento odontológico, que foram registradas em formulário elaborado para aplicação aos pais (Anexo 2).

- Hábitos de higiene bucal e dieta da criança, que foram registrados em formulário preenchido pelas crianças antes da realização dos exames (Anexo 3).

\subsection{Critérios para a produção dos dados}

\subsubsection{Condições físicas, instrumental e examinador}

Um exame clínico das crianças participantes foi realizado na própria escola, em carteiras escolares sob luz natural e utilizando-se apenas espelho clínico plano e sonda periodontal especifica (CPI), seguindo os critérios e fichas estabelecidas pela Organização Mundial da Saúde (WHO 1997). Os exames foram realizados entre os meses de outubro de 2001 e março de 2002. Nos meses de dezembro de 2001, janeiro e fevereiro de 2002 as crianças estavam em férias escolares. Foi planejado que os exames ocorressem apenas no segundo semestre de 2001 por dois examinadores, mas, devido aos inesperados feriados do racionamento de energia, da greve policial ocorrida no Estado da Bahia que provocaram a suspensão das aulas, 
bem como da indisponibilidade de horários do segundo examinador, foi impossivel a conclusão dos exames no periodo previsto, estendendo-se o período de exames para março de 2002.

Os instrumentais utilizados foram esterilizados previamente ao dia do exame, bem como foram utilizados, luvas, máscaras e gorros descartáveis para a equipe de trabalho; enfim todas as medidas de biossegurança necessárias ao exame clínico foram providenciadas.

Os exames foram executados por um examinador, que foi treinado e calibrado a fim de assegurar a uniformidade de critérios e que registrou os dados coletados na ficha apresentada no Anexo 4.

Para medir a reprodutibilidade e concordância do examinador, um grupo de trinta crianças, que não foram incluídas na pesquisa, foi avaliado duas vezes em dias diferentes e os valores de Kappa intra-examinador foram calculados para as unidades dentais examinadas segundo as condições estudadas (BULMAN e OSBORN 1989).

Em adição à calibração prévia do examinador, durante o curso dos exames, $10 \%$ destes foram repetidos, ou melhor, a cada dez exames executados retornou-se ao primeiro, para se calcular a reprodutibilidade dos resultados durante o levantamento.

Segundo FRIAS (2000), a utilização de planilha de dupla entrada e do coeficiente de Kappa não requer nenhum recurso tecnológico sofisticado, recomendando-se que estes instrumentos sejam adotados mais freqüentemente nas pesquisas epidemiológicas na área de saúde bucal. Tais instrumentos podem ser muito úteis no desenvolvimento de pesquisas mais precisas, portanto com maior grau de confiabilidade.

\subsection{2. Índice CPOD e Necessidades de Tratamento}

O sistema padrão de código numérico para a dentição permanente foi utilizado para registrar a condição da dentição. Caso um dente permanente e 
um dente decíduo estivessem ocupando o mesmo espaço dentário, somente a condição do dente permanente era registrada.

O exame foi conduzido com um espelho clínico plano e sonda periodontal - CPI, sendo adotada a padronização de códigos e critérios recomendada pela Organização Mundial de Saúde (WHO 1997). Foram utilizados como critérios de decisão complementar o manual de instruções utilizado no levantamento do Estado de São Paulo, elaborado pelos professores da Faculdade de Saúde Pública da USP (USP-FSP 1998).

Todos os dentes eram examinados assim que qualquer superficie da coroa ou parte da mesma estivesse presente no arco dentário, sendo anotado um código para cada unidade dentária. Os critérios e códigos foram:

0 - Coroa hígida. Não havia evidência de cárie. Estágios iniciais da doença não eram levados em consideração. Os seguintes sinais deveriam ser codificados como hígidos:

- manchas esbranquiçadas;

- descolorações ou manchas rugosas resistentes à pressão da sonda $\mathrm{CPI}$;

- sulcos e fissuras do esmalte, manchados mas que não apresentavam sinais visuais de base amolecida, esmalte socavado, ou amolecimento das paredes, detectáveis com a sonda CPI;

- áreas escuras, brilhantes, duras e fissuradas do esmalte de um dente com fluorose moderada ou severa;

- lesões que, com base na sua distribuição ou história, ou exame táctil/visual, resultassem de abrasão.

Todas as lesões questionáveis deveriam ser codificadas como dente hígido.

1- Coroa Cariada. Sulco, fissura ou superficie lisa apresentando cavidade evidente, ou tecido amolecido na base ou descoloração do esmalte ou de parede ou havia uma restauração temporária. A sonda CPI deveria ser empregada para confirmar as evidências visuais de cárie nas 
superficies oclusal, vestibular e lingual. Na dúvida, considerava-se o dente higido.

Na presença de cavidade originada por cárie, mesmo sem doença no momento do exame, o manual da FSP-USP adota como regra de decisão considerar o dente atacado por cárie, registrando-se cariado. Entretanto, este enfoque epidemiológico não implica admitir que há necessidade de uma restauração.

2 - Coroa restaurada, mas cariada. Havia uma ou mais restaurações e ao mesmo tempo uma ou mais áreas estavam cariadas. Não houve distinção entre cárie primária e secundária, ou seja, se as lesões estavam ou não em associação física com a(s) restauração(ões).

3 - Coroa restaurada e sem cárie. Havia uma ou mais restaurações definitivas e inexistia cárie primária ou recorrente. $O$ dente, com coroa, colocada, devido à cárie, foi incluido nesta categoria. Se a coroa resultava de outras causas, como suporte de prótese, foi codificado como 7.

4 - Dente perdido devido à cárie. Um dente permanente extraído por causa de cárie e não por outras razões.

5 - Dente permanente perdido por outra razão. A ausência se devia a razões ortodônticas, periodontais, traumáticas ou congênitas.

6 - Selante. Havia um selante de fissura ou a fissura oclusal foi alargada para receber um compósito. Se o dente possuia selante e estava cariado, prevalecia o código 1.

Embora na padronização da OMS haja referência apenas à superficie oclusal, o manual da FSP-USP indica o registro quando a presença de selante foi localizado em qualquer superficie dentária.

7 - Apoio de ponte ou coroa. Indicando um dente que era parte de uma prótese fixa. Também utilizado para coroas instaladas por outras razões que não a cárie ou para dentes com facetas estéticas. Os dentes ausentes substituídos por pônticos de próteses eram codificados como 4 ou 5 . 
8 - Dente não erupcionado. Restrito à dentição permanente e desde que não existisse dente temporário no espaço livre. Não incluindo dentes perdidos por problemas congênitos, trauma, etc.

T - Trauma (fratura). Parte da superficie coronária foi perdida em consequência de trauma e não havia evidência de cárie.

9 - Dente Excluído. Aplicado a qualquer dente permanente que não pudesse ser examinado (bandas ortodônticas, hipoplasias severas, etc.).

Conforme a recomendação do manual da FSP-USP, quando há 5 ou mais dentes com bandas o portador é excluído da amostra. Braquetes, em qualquer número, não inviabilizam os exames e, assim, não constituem obstáculo para aproveitamento do elemento amostral.

Para o cálculo do CPOD, o componente $\mathrm{C}$ incluiu todos os dentes com código 1 ou 2, o componente $P$ compreendeu os dentes codificados com 4 e o componente $O$ incluiu somente os dentes com código 3. A base para os cálculos do CPOD é 32 , ou seja, todos os dentes permanentes inclusive os terceiros molares. Os dentes codificados com 6 (selamento de fissura) ou 7 (dente suporte de prótese, coroas protéticas ou facetadas) não são incluídos no cálculo do CPOD.

\section{- Necessidade de tratamento}

Imediatamente após registrar a condição dentária e antes de passar ao espaço dentário seguinte devia-se registrar o tratamento indicado. Os códigos e critérios para as necessidades de tratamento foram:

0 - Nenhum tratamento. A coroa e a raiz estavam hígidas, ou o dente não podia ou não devia ser extraído ou receber qualquer outro tratamento.

1 - Restauração de uma superficie dentária.

2 - Restauração de duas ou mais superfícies dentárias.

3 - Coroa por qualquer razão.

4 - Coroa veener ou faceta estética. 
5 - Tratamento pulpar e restauração. $O$ dente necessitava tratamento endodôntico previamente à colocação da restauração ou coroa, devido à cárie profunda e extensa, ou mutilação ou trauma.

A sonda não deveria ser inserida no fundo de uma cavidade para confirmar a presença de uma provável exposição pulpar.

6 - Extração. Um dente era registrado como "indicado para extração", dependendo das possibilidades de tratamento disponiveis, quando:

- a cárie destruiu o dente de tal modo que não era possivel restaurá-lo;

- a doença periodontal progrediu tanto que o dente estava com mobilidade, havia dor ou o dente estava sem função e, no julgamento clínico do examinador, não poderia ser recuperado através de tratamento periodontal;

- um dente precisava ser extraído para confecção de uma prótese; ou,

- a extração era necessária por razões ortodônticas ou estéticas, ou devido à impactação.

\section{7 - Remineralização de Mancha Branca.}

8 - Selante. A indicação de selantes de fóssulas e fissuras não é uma unanimidade entre os cirurgiōes-dentistas, havendo profissionais que não $o$ indicam em nenhuma hipótese. Nesta pesquisa a necessidade de selante foi registrada. Sua indicação, conforme regra de decisão adotada pela USP/FSP (1998), foi feita na presença simultânea das seguintes condições:

- $\quad$ o dente estava presente na cavidade bucal a menos de 2 (dois) anos;

- o dente homólogo apresentava cárie ou foi atingido pela doença;

- havia presença de placa clinicamente detectável evidenciando higiene bucal precária. 
Um dos códigos $1,2,7$ ou 8 foi utilizado para indicar 0 tratamento necessário para:

- tratar as lesões de cárie iniciais, primárias ou secundárias;

- tratar descoloração de um dente ou um defeito de desenvolvimento;

- reparar dano causado por trauma, abrasão, erosão ou atrição; ou,

- substituir restaurações ou selantes insatisfatórios se existissem uma ou mais das seguintes condições:

- margem deficiente, permitindo ou em vias de permitir infiltração na dentina. A decisão deveria ser tomada com base no senso clinico do examinador, após ter inserido a sonda CPI na margem entre a restauração e o tecido duro ou após observar uma significativa descoloração do esmalte adjacente;

- excesso marginal, causando irritação local do tecido gengival e não podendo ser removido através de um ajuste da restauração;

- fratura, que pudesse causar a perda da restauração ou infiltração marginal;

- descoloração.

\subsection{3 Índice Periodontal Comunitário (CPI)}

Três indicadores das condições periodontais são utilizados para a avaliação do Índice Periodontal Comunitário: sangramento gengival, cálculo e bolsas periodontais.

Sonda CPI - Uma sonda leve, especialmente idealizada para o CPI, com uma ponta esférica de $0,5 \mathrm{~mm}$, com uma faixa preta entre $3,5 \mathrm{e}$ $5,5 \mathrm{~mm}$ e anéis de 8,5 e $11,5 \mathrm{~mm}$ da ponta esférica foi utilizada.

Sextantes - A boca foi dividida em sextantes definidos pelos dentes: 18-14, $13-23,24-28,38-34,33-43$ e $44-48$. A presença de dois ou 
mais dentes sem indicação de exodontia foi pré-requisito ao exame do sextante. Sem isso, o sextante era cancelado.

Dentes-índices - Para indivíduos abaixo da idade de vinte anos, 6 dentesíndices são examinados: $16,11,26,36,31$ e 46 . A não inclusão do exame dos segundos molares permanentes foi feita a fim de evitar o registro do aprofundamento de sulco associado com a erupção, classificando-o como bolsa periodontal. Pelo mesmo motivo, quando são examinadas crianças, com menos de 15 anos, as bolsas periodontais não devem ser registradas, isto é, somente o sangramento e a presença de cálculos devem ser levados em consideração.

Exame - Os dentes-índices foram examinados nas superfícies vestibular e lingual, abrangendo as regiōes mesial, média e distal. Os procedimentos de exame deveriam ser iniciados pela área disto-vestibular, passando-se para a área média e daí para a mésio-vestibular. Após isto, inspecionava-se as áreas linguais, indo de distal para mesial. A sonda deveria ser introduzida levemente no sulco gengival ou na bolsa periodontal, paralela em relação ao longo eixo do dente, seguindo a configuração anatômica da superfície radicular. A força de sondagem deveria ser inferior a 20 gramas. Um teste prático para o estabelecimento desta força é a colocação da ponta da sonda sob a unha do polegar pressionando-a até obter ligeira isquemia.

Registros - Os dentes-indices, ou todos os dentes remanescentes no sextante quando não houver dente indicador, deveriam ser sondados. Em cada sextante foi feita uma única anotação relativa à pior situação encontrada. Os códigos foram:

0 . sextante hígido

1. sextante com sangramento (observado, diretamente ou com o espelho clínico, após a sondagem). 
2. cálculos ( qualquer quantidade mas com toda área preta da sonda visivel ).

3. bolsa periodontal de 4 a $5 \mathrm{~mm}$, (margem gengival na área preta da sonda).

4. bolsa periodontal de $6 \mathrm{~mm}$ ou mais, (área preta da sonda, não está visível).

$X$. sextante excluido, (menos de dois dentes presentes).

9. sextante não examinado.

Em crianças com menos de quinze anos não são registrados os critérios 3 e 4 . Bem como, em relação ao período de tempo para a observação do sangramento à sondagem, é recomendado pelo manual da USP/FSP um tempo de observação de 10 a 30 segundos.

\subsection{4 Índice Estético Dentário (DAl)}

É recomendável que este índice seja utilizado em grupos etários nos quais não haja mais dentes deciduos, portanto escolares que estivessem ainda na fase da dentição mista não fizeram parte da amostra para o cálculo deste índice. Isto porque, o período de transição da dentição decídua a permanente pode acrescentar fatores de confusão para a utilização de índices oclusais na medida em que, nesse período existe um grande dinamismo biológico (GRABER 1974).

Dentição - O número de incisivos, caninos e pré-molares permanentes perdidos, nas arcadas superior e inferior, deveria ser contado e registrado na ficha de avaliação. Deveria ser anotado o motivo pelo qual foram extraidos. Os dentes não deveriam ser considerados perdidos quando o seu respectivo espaço estivesse fechado ou se prótese(s) fixa(s) estivesse(em) instalada(s).

Espaç - Foi avaliado com base no registro das seguintes condições:

- Apinhamento no segmento incisal. Tanto os segmentos anteriores superiores quanto inferiores deveriam ser examinados. 
O segmento é definido de canino a canino. Considerando-se apinhamento quando havia dentes com giroversão ou mal posicionados no arco. Não se considerou apinhamento quando os quatro incisivos estavam adequadamente alinhados e um ou ambos os caninos estavam deslocados. O registro deveria ser feito da seguinte forma:

0 . sem apinhamento.

1. apinhamento em um segmento .

2. apinhamento em dois segmentos.

Caso existisse qualquer dúvida, o índice mais baixo deveria ser registrado.

- Espaçamento no segmento incisal. Tanto os segmentos anteriores superiores quanto inferiores deveriam ser examinados. Havia espaçamento quando a distância inter-caninos era suficiente para o adequado posicionamento de todos os incisivos e ainda sobrava espaço e/ou um ou mais incisivos tinham uma ou mais superficies proximais sem estabelecimento de contato interdental.

$O$ registro deveria ser feito da seguinte forma:

0. sem espaçamento.

1. espaçamento em um segmento.

2. espaçamento em dois segmentos.

Caso existisse qualquer dúvida, o valor mais inferior deveria ser considerado.

- Diastema incisal. É definido como o espaço em milimetros entre os dois incisivos centrais superiores permanentes, quando estes perdem o ponto de contato. Diastemas em outras localizações ou no arco inferior (mesmo envolvendo incisivos não eram considerados). $O$ valor a ser registrado correspondeu ao tamanho em milímetros $(\mathrm{mm})$ medido com a sonda $\mathrm{CPI}$.

- Desalinhamento maxilar anterior. Podem ser giroversões ou deslocamentos em relação ao alinhamento normal e podem 
ocorrer com ou sem apinhamento. Os quatro incisivos superiores deveriam ser examinados registrando-se a maior irregularidade entre dentes adjacentes. A medida era feita, em $\mathrm{mm}$, com a sonda CPI. A ponta da sonda era colocada sobre a superficie vestibular do dente posicionado mais para lingual sendo a sonda mantida paralela ao plano oclusal e formando um ângulo reto com a linha do arco.

- Desalinhamento mandibular anterior. A medida é a mesma realizada na arcada superior exceto que era feita na arcada inferior.

Oclusão - É avaliada com base nas medidas da sobressaliência (overjet) maxilar anterior, da sobressaliência (overjet) mandibular anterior, da mordida aberta vertical anterior e da relação molar antero-posterior. Os códigos e condições eram:

- Sobressaliência maxilar anterior. A relação horizontal entre os incisivos era medida com os dentes em oclusão cêntrica, utilizandose a sonda CPI, posicionada em plano paralelo ao plano oclusal. $O$ overjet é a distância, em $\mathrm{mm}$, entre as superfícies vestibulares do incisivo superior mais proeminente $e$ do incisivo inferior correspondente. A maior sobressaliência era registrada. A sobressaliência não era registrada se todos os incisivos superiores fossem perdidos ou se estivessem em mordida cruzada. Quando a mordida era do tipo topo-a-topo, o valor era zero.

- Sobressaliência mandibular anterior. É caracterizada quando algum incisivo inferior se posiciona anteriormente ou por vestibular em relação ao seu correspondente superior. A protusão mandibular, ou mordida cruzada era medida com a sonda CPI e registrada em milímetros. Os procedimentos para mensuração eram os mesmos que foram descritos para a sobressaliência maxilar anterior. Não foram levadas em conta (sendo, portanto, desconsideradas) as situações em que havia giroversão de incisivo inferior, com apenas parte da borda incisal em cruzamento. 
- Mordida aberta vertical anterior. Se há falta de ultrapassagem vertical entre incisivos opostos caracteriza-se uma situação de mordida aberta. O tamanho da distância, entre as bordas incisais, era medido com a sonda $\mathrm{CPI}$ e o valor, em $\mathrm{mm}$, registrado no campo correspondente.

- Relação molar antero-posterior. A avaliação era feita com base na relação entre os primeiros molares permanentes, superior e inferior. Se isso não é possivel, porque um ou ambos estão ausentes, não completamente erupcionados, ou alterados em virtude de cárie ou restaurações, então os caninos e pré-molares eram utilizados. Os lados direito e esquerdo eram avaliados com os dentes em oclusão e apenas o maior desvio da relação molar normal era registrado. Os seguintes códigos foram utilizados:

0. normal.

1. meia cúspide. O primeiro molar inferior está deslocado meia cúspide para mesial ou distal em relação à posição normal.

2. cúspide inteira. O primeiro molar inferior está deslocado uma cúspide para mesial ou distal em relação à posição normal.

A seguinte equação de regressão foi utilizada para o cálculo dos valores de DAI padrão:

(dentes permanentes perdidos $\times 6)+$ (apinhamento) + (espaçamento $)+($ diastema $\times 3)+($ desalinhamento maxilar anterior $)+$ (desalinhamento mandibular anterior) + (sobressaliência maxilar anterior $\times 2)+($ sobressaliência mandibular anterior $\times 4)+($ mordida aberta anterior $\times 4)+($ relação molar antero posterior $\times 3)+13$.

A severidade da oclusopatia foi classificada segundo apresentado no Quadro 1. 
Quadro 1 - Distribuição dos valores DAl padrão.

\begin{tabular}{|l|c|c|}
\hline Severidade da oclusopatia & Indicação de tratamento & Valor do DAI \\
\hline $\begin{array}{l}\text { Sem anormalidades ou } \\
\text { oclusopatias leves }\end{array}$ & $\begin{array}{c}\text { Sem necessidade ou } \\
\text { necessidade leve }\end{array}$ & $\leq 25$ \\
\hline Oclusopatia definida & Eletivo & $26-30$ \\
\hline Oclusopatia severa & Altamente desejável & $31-35$ \\
\hline $\begin{array}{l}\text { Oclusopatia muito severa ou } \\
\text { incapacitante }\end{array}$ & Fundamental & $\geq 36$ \\
\hline
\end{tabular}

Fonte: Cons et al 1986 apud (WHO 1997)

\subsection{5 Índice de Fluorose Dentária}

O índice recomendado pela OMS é o índice de Dean (WHO 1997). Todos os dentes são examinados, mas a avaliação da condição individual é feita levando-se em conta apenas os dois dentes mais afetados (se esses dois dentes não estiverem comprometidos de modo semelhante, o valor do menos afetado entre os dois será registrado). As lesões fluoróticas são usualmente bilaterais e simétricas, e tendem a apresentar estrias horizontais. Os pré-molares e segundos molares são os dentes mais freqüentemente comprometidos, seguindo-se os incisivos superiores. Incisivos inferiores são menos afetados.

Os códigos e critérios foram:

0. Normal. O esmalte apresentava translucidez usual com estrutura semi-vitriforme. A superfície era lisa, polida, cor creme clara.

1. Questionável. O esmalte revelava pequena diferença em relação à translucidez normal, com ocasionais manchas esbranquiçadas. Este código era usado quando a classificação normal não se justificava.

2. Muito leve. Áreas esbranquiçadas, opacas, pequenas manchas espalhadas irregularmente pelo dente, mas envolvendo não mais que $25 \%$ da superfície. Inclui opacidades claras com 1 a $2 \mathrm{~mm}$ na ponta das cúspides de molares. 
3. Leve. A opacidade era mais extensa do que para o código 2 , mas não envolvia mais que $50 \%$ da superfície dentária.

4. Moderada. Todo o esmalte dentário estava afetado e as superfícies sujeitas à atrição mostravam-se desgastadas. Haviam manchas castanhas ou amareladas freqüentemente desfigurantes.

5. Severa. A hipoplasia estava generalizada e a própria forma do dente poderia estar afetada. O sinal mais evidente era a presença de depressões no esmalte, que parece corroído. Manchas castanhas generalizadas.

8. Excluído. Quando, por alguma razão, um indivíduo não pudesse ser avaliado quanto à fluorose dentária (por exemplo, um dente com coroa protética).

\section{Sem informação.}

\subsubsection{Etnia}

Para classificação dos indivíduos foram adotadas as categorias preconizadas pela Fundação Instituto Brasileiro de Geografia e Estatística (IBGE), utilizadas no Censo de 1991: amarela, branca, negra e parda. A variável etnia foi expressa pela cor da pele e por algumas características fenotípicas através dos seguintes critérios e códigos:

A - amarela: pele branco-amarela; olhos oblíquos, repuxados.

B - branca: pele branca; cabelo liso ou ondulado fino (de louro a negro); nariz estreito e proeminente; lábios finos (ou de espessura mediana); gengiva cor rósea (com suas variações normais devidas à queratinização e vascularização).

$\mathrm{N}$ - negra: pele castanho-escura ou negra; cabelo ondulado, encarapinhado ou em anel, geralmente escuro; nariz largo ou achatado; gengiva pigmentada pelo acúmulo de melanina.

$P$ - parda: pele de coloração entre branca e negra ("mulato", "moreno"); traços evidenciando miscigenação; impossibilidade de incluir o indivíduo nas categorias "branco", "negro" ou "amarelo". 


\subsubsection{Escolaridade, renda familiar, acesso ao atendimento odontológico, hábitos de higiene bucal e dieta}

Visando então, analisar algumas características sócio-culturais e as relacionadas à higiene e dieta, foram elaborados um formulário direcionado para os pais e outro para as crianças (Anexos 2 e 3 ).

\subsection{Análise estatística}

O programa de computador MICROSOFT EXCEL 2000 Versão 7.0 foi utilizado para o cadastro das escolas e alunos, montagem do banco de dados e cálculo do Índice de Kappa. As variáveis foram analisadas através de distribuição de freqüências, obtenção de médias, desvio padrão, teste de diferença de médias e testes de correlação. $O$ nível de significância utilizado foi de $\alpha=0,05$. Buscou-se verificar diferenças dos índices segundo tipo de escola, sexo e etnia. Para esta última variável além da análise por tipo de escola realizou-se a análise dos dados agrupados.

Para verificação da representatividade geográfica das escolas na área urbana, estas foram localizadas através dos seus endereços em um mapa digital georeferenciado no laboratório de geoplanejamento (GEOPLAN) da UEFS.

As possiveis correlações entre os índices foram investigadas, apesar de não serem objeto de estudo neste trabalho. Isto objetivou verificar o relacionamento entre as doenças estudadas.

Para análises estatísticas mais sofisticadas o programa SPSS INC (Statistical Package for Social Science) Versão 9.0 para Windows foi empregado.

\subsection{Aspectos éticos}

Para realização desta pesquisa, o projeto foi encaminhado ao Comitê de Ética da FSP e aprovado segundo Parecer COEF nº 036/01 (Anexo 7). 
Foi solicitada à Diretoria Regional de Educação - 02, que coordena as atividades escolares no município de Feira de Santana, autorização para a realização do estudo nas escolas, através de uma carta encaminhada à Diretoria das escolas (Anexo 5), bem como, foi encaminhada uma carta aos pais ou responsável da criança, explicitando as caracteristicas da pesquisa e solicitando a autorização para o exame do escolar através do consentimento esclarecido. Esta carta foi redigida seguindo os princípios estabelecidos pela Resolução $n^{\circ}$ 196/96 do Conselho Nacional de Saúde que regulamenta pesquisas envolvendo seres humanos e segundo modelo utilizado pela FSPUSP (Anexo 6).

\subsection{Dificuldades na realização da pesquisa}

Durante a fase de planejamento da pesquisa uma dificuldade encontrada foi a questão dos registros, próprios da burocracia pública, em relação às informações para a caracterização da população de referência e das ações de saúde bucal dirigidas a esta população. Evidenciou-se a necessidade de consolidação de um sistema de arquivamento e ordenação dos documentos públicos que facilite o acesso às informações para a população em geral, para a academia na elaboração de trabalhos científicos e para a própria administração pública na organização de programas públicos.

A falta de uma equipe de trabalho e de pessoal de apoio para a realização dos exames e para suporte, agravada com a simultânea atividade docente dificultou o desenvolvimento da pesquisa.

Outras dificuldades importantes foram alterações do calendário escolar, decorrentes de feriados e suspensão das aulas, não esperadas, que geraram algumas perdas na amostra sorteada. 


\section{RESULTADOS}

\subsection{AMOSTRA}

A figura 1 mostra o tamanho das amostras definidas segundo o tipo de escola, fazendo um paralelo com o número de exames realizados e o percentual de perdas.

Figura 1- Tamanho da amostra, número de exames realizados $\mathrm{e}$ percentuais de perdas em cada grupo de escolas. Feira de Santana - BA, 2002.

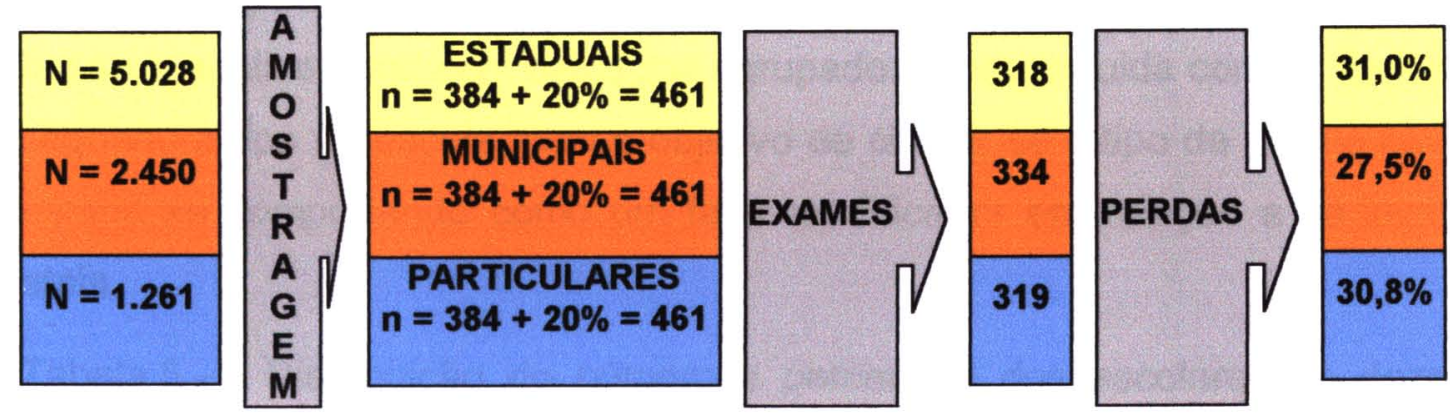

O número total $(n=971)$ de crianças examinadas se distribui de forma relativamente balanceada em cada tipo de escola. Em relação à composição por sexo, a distribuição se apresentou equilibrada com ligeiro predomínio do sexo feminino, ou seja, $513(52,8 \%)$ crianças sobre $458(47,2 \%)$ do sexo masculino. Quando a composição é distribuída por tipo de escola observouse que este predomínio do sexo feminino permanece, exceto para as escolas municipais. Mas estas diferenças na composição por sexo não foram estatisticamente significativas em nivel de $5 \%\left(X^{2}=3,66 ; p=0,160\right)$ (Tabela 4).

Tabela 4 - Distribuição do número e percentual dos escolares de doze anos examinados segundo sexo e tipo de escola. Feira de Santana - BA, zona urbana, 2002.

\begin{tabular}{ccccccc}
\hline Sexo & \multicolumn{2}{c}{ Estadual } & \multicolumn{2}{c}{ Municipal } & \multicolumn{2}{c}{ Particular } \\
\cline { 2 - 7 } & № & $\%$ & № & $\%$ & № & $\%$ \\
\hline Feminino & 171 & 53,8 & 163 & 48,8 & 179 & 56,1 \\
Masculino & 147 & 46,2 & 171 & 51,2 & 140 & 43,9 \\
\hline Total & $\mathbf{3 1 8}$ & $\mathbf{1 0 0}$ & $\mathbf{3 3 4}$ & $\mathbf{1 0 0}$ & $\mathbf{3 1 9}$ & $\mathbf{1 0 0}$ \\
\hline \hline
\end{tabular}


Quanto à etnia, não foi encontrado escolar do grupo étnico "amarelo" em toda a amostra e nos demais grupos a distribuição ocorreu da seguinte forma: $164(16,9 \%)$ de escolares "brancos", 397(40,9\%) "negros" e 410 $(42,2 \%)$ de "pardos". A distribuição segundo tipo de escola exibe um equilibrio do grupo de "pardos". O grupo de "negros" predomina nas escolas estaduais e municipais. O grupo de "brancos" apresenta seu maior percentual nas escolas particulares. A distribuição se mostrou desigual em nível de $5 \%\left(X^{2}=217,35 ; p=0,000\right.$ ) (Tabela 5). Em função desta desigualdade, na análise estatistica dos indices investigados segundo etnia, fez-se a análise geral com os dados agrupados e em seguida com os dados segundo o tipo de escola, com o objetivo de checar se o tipo de escola não estaria se comportando como um fator modificador em relação a variável etnia.

Tabela 5 - Distribuição do número e percentual dos escolares de doze anos examinados segundo etnia e tipo de escola. Feira de Santana - BA, zona urbana, 2002.

\begin{tabular}{ccccccc}
\hline \multirow{2}{*}{ Etnia } & \multicolumn{2}{c}{ Estadual } & \multicolumn{2}{c}{ Municipal } & \multicolumn{2}{c}{ Particular } \\
\cline { 2 - 7 } & No & $\%$ & NN $^{\mathbf{o}}$ & $\%$ & $\mathbf{N}^{\mathbf{O}}$ & $\%$ \\
\hline "Parda" & 128 & $\mathbf{4 0 , 2}$ & 134 & 40,1 & 148 & 46,4 \\
"Negra" & 170 & 53,5 & 180 & 53,9 & 47 & 14,7 \\
"Branca" & 20 & 6,3 & 20 & 6,0 & 124 & 38,9 \\
\hline Total & $\mathbf{3 1 8}$ & $\mathbf{1 0 0}$ & $\mathbf{3 3 4}$ & $\mathbf{1 0 0}$ & $\mathbf{3 1 9}$ & $\mathbf{1 0 0}$ \\
\hline
\end{tabular}

A distribuição amostral de 971 escolares anteriormente descrita foi utilizada para o cálculo dos índices CPOD, CPI e Fluorose. Para o cálculo do DAl, a representação amostral foi diferente, a qual está melhor descrita no tópico 5.5 deste trabalho.

A distribuição das 54 escolas sorteadas no municipio mostrou a boa representatividade na área urbana, observada não só na região central como também nas áreas periféricas (Figura 2). 
Figura 2 - Distribuição geográfica das escolas incluídas na pesquisa,

segundo tipo, no Município de Feira de Santana - BA, 2002

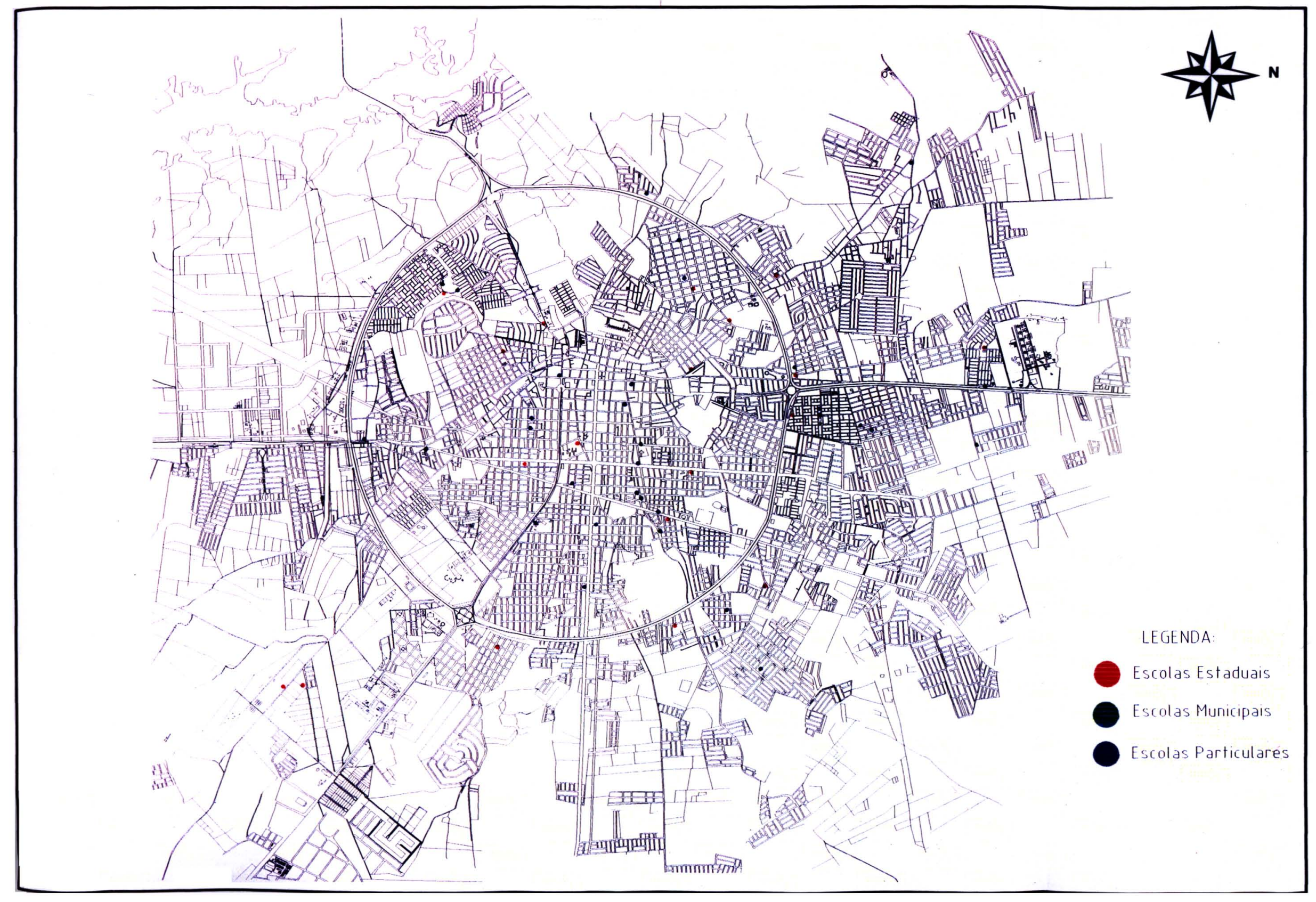




\subsection{CALIBRAÇÃO}

Os índices de Kappa calculados na calibração inicial e nos reexames se encontram na tabela 6.

Tabela 6 - Indices de Kappa, intra-examinador, calculados na calibração inicial e nos reexames para as condições examinadas em escolares de doze anos de idade. Feira de Santana - BA, zona urbana, 2002.

\begin{tabular}{lcc}
\hline \multicolumn{1}{c}{ Índice de Kappa } & Calibração inicial & Reexames \\
\hline CPOD & 0,90 & 0,99 \\
Necessidade de tratamento & 0,64 & 0,94 \\
CPI & 0,46 & 0,92 \\
Dentição & 1,00 & 1,00 \\
Apinhamento & 0,74 & 0,97 \\
Espaçamento & 0,86 & 1,00 \\
Diastema & 1,00 & 0,98 \\
Desalinhamento maxilar & 0,82 & 0,94 \\
Desalinhamento mandibular & 0,55 & 0,95 \\
Sobressaliência maxilar & 0,58 & 0,94 \\
Sobressaliência mandibular & 1,00 & 1,00 \\
Mordida aberta & 1,00 & 0,98 \\
Relação molar & 0,63 & 0,93 \\
Fluorose dentária & 0,79 & 0,84 \\
\hline
\end{tabular}

Durante a fase de calibração inicial, com trinta e uma crianças, segundo a classificação do índice (WHO 1997), as condições com menores indices de Kappa foram CPI, desalinhamento mandibular e sobressaliência maxilar, classificando-as como de concordância moderada de critérios do examinador. Para necessidade de tratamento, apinhamento, relação molar e fluorose, a concordância foi substancial. No CPOD, espaçamento e desalinhamento maxilar foi quase perfeita. $\mathrm{Na}$ dentição, diastema, sobressaliência mandibular e mordida aberta, a concordância foi perfeita.

O cálculo do indice para os cem reexames demonstrou que durante a fase de exames na pesquisa a concordância foi superior à fase de calibração 
inicial, com indices classificados como de quase perfeita ou perfeita concordância, mostrando excelente reprodutibilidade de diagnóstico.

Para maiores esclarecimentos em relação aos Índices de Kappa calculados ver os quadros apresentados no Anexo 8.

\subsection{CÁRIE DENTÁRIA E NECESSIDADES DE TRATAMENTO}

A seguir estão descritos os resultados para o indice CPOD e Necessidades de Tratamento.

Tabela 7 - Distribuição do número e percentual dos escolares de doze anos examinados segundo valores do índice CPOD e tipo de escola. Feira de Santana - BA, zona urbana, 2002.

\begin{tabular}{ccccccc}
\hline Valor do CPOD & \multicolumn{2}{c}{ Estadual } & \multicolumn{2}{c}{ Municipal } & \multicolumn{2}{c}{ Particular } \\
\cline { 2 - 7 } & No $^{\mathbf{0}}$ & $\%$ & No $^{\mathbf{0}}$ & $\%$ & $\mathbf{N}^{\circ}$ & $\%$ \\
\hline $\mathbf{0}$ & 113 & 35,5 & 128 & 38,3 & 109 & 34,2 \\
$\mathbf{1}$ & 64 & 20,1 & 45 & 13,5 & 39 & 12,2 \\
$\mathbf{2}$ & 39 & 12,3 & 44 & 13,2 & 38 & 11,9 \\
$\mathbf{3}$ & 33 & 10,4 & 33 & 9,9 & 31 & 9,7 \\
$\mathbf{4}$ & 37 & 11,6 & 31 & 9,3 & 41 & 12,9 \\
$\mathbf{5}$ & 8 & 2,5 & 17 & 5,1 & 28 & 8,8 \\
$\mathbf{6}-\mathbf{1 7}$ & $\mathbf{2 4}$ & $\mathbf{7 , 5}$ & 36 & 10,8 & 33 & 10,3 \\
\hline Total & $\mathbf{3 1 8}$ & $\mathbf{1 0 0}$ & $\mathbf{3 3 4}$ & $\mathbf{1 0 0}$ & $\mathbf{3 1 9}$ & $\mathbf{1 0 0}$ \\
\hline
\end{tabular}

Observa-se que mais de $30,0 \%$ dos escolares examinados, independente do tipo de escola, estão livres de cárie $(C P O D=0)$ e que $78,3 \%$ das crianças nas escolas estaduais, $74,9 \%$ nas municipais e $68,0 \%$ nas particulares apresentam CPOD $\leq 3$. Isto mostra também que apenas um terço ou menos das crianças concentram um maior número de dentes com prevalência de cárie, fato ao qual denomina-se polarização (Tabela 7).

A distribuição percentual dos valores do CPOD segundo os tipos de escola diferem nos valores 0,1 e 5 (Tabela 7 e Figura 3 ). No entanto, estas diferenças não foram significativas em nivel de $5 \%\left(X^{2}=38,75 ; p=0,085\right)$. 
Figura 3 - Distribuição percentual de escolares aos doze anos segundo os valores do CPOD e tipo de escola, Feira de Santana - BA, zona urbana, 2002.

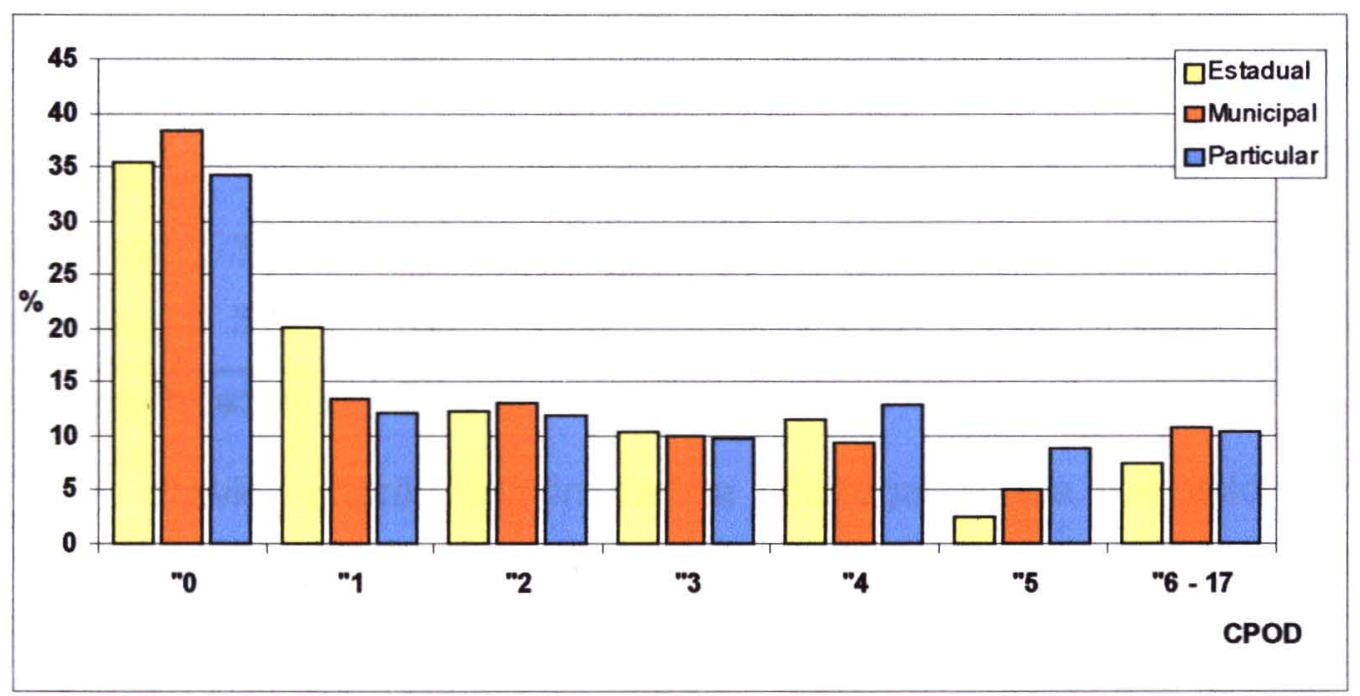

$\mathrm{Na}$ distribuição dos dentes segundo os componentes do índice CPOD pode-se observar a participação pouco expressiva do componente $\mathrm{P}$ e uma maior participação do componente $C$ nas escolas públicas e do componente O nas particulares (Tabela 8). Estes dados mostram que as composições do índice CPOD segundo o tipo de escola, pública ou particular, não são iguais e as diferenças foram estatisticamente significativas em nível de $5 \%\left(X^{2}=\right.$ 535,52; $p=0,000$ ). As médias dos componentes e dos índices CPOD por tipo de escola também mostram estas diferenças de composição (Tabela 9).

Tabela 8 - Distribuição do número e percentual de dentes permanentes de escolares de doze anos de idade, segundo componentes do índice CPOD e tipo de escola. Feira de Santana - BA, zona urbana, 2002.

\begin{tabular}{lcccccccc}
\hline Tipo de & \multicolumn{2}{c}{ C } & \multicolumn{2}{c}{ P } & \multicolumn{2}{c}{ O } & \multicolumn{2}{c}{ CPOD } \\
\cline { 2 - 8 } Escola & D & $\%$ & D & $\%$ & D & $\%$ & D & $\%$ \\
\hline Estadual & 445 & 74,5 & 40 & 6,7 & 112 & 18,8 & 597 & 100 \\
Municipal & 624 & 86,2 & 32 & 4,4 & 68 & 9,4 & 724 & 100 \\
Particular & 274 & 35,9 & 12 & 1,6 & 477 & 62,5 & 763 & 100 \\
\hline Total & $\mathbf{1 . 3 4 3}$ & $\mathbf{6 4 , 5}$ & $\mathbf{8 4}$ & $\mathbf{4 , 0}$ & $\mathbf{6 5 7}$ & $\mathbf{3 1 , 5}$ & $\mathbf{2 . 0 8 4}$ & $\mathbf{1 0 0}$ \\
\hline
\end{tabular}


Tabela 9 - Média dos componentes e do índice CPOD segundo tipo de escola, desvio padrão e intervalos de confiança de $95 \%$. Feira de Santana - BA, zona urbana, 2002.

\begin{tabular}{lcccccccc}
\hline $\begin{array}{c}\text { Tipo de } \\
\text { Escola }\end{array}$ & No & $\overline{\mathbf{C}}$ & $\overline{\mathbf{P}}$ & $\overline{\mathbf{O}}$ & $\overline{\text { CPOD }}$ & dp & [LI & LS] \\
\hline Estadual & 318 & 1,40 & 0,14 & 0,35 & 1,89 & 2,14 & 1,65 & 2,13 \\
Municipal & 334 & 1,87 & 0,10 & 0,20 & 2,17 & 2,62 & 1,89 & 2,45 \\
Particular & 319 & 0,86 & 0,03 & 1,50 & 2,39 & 2,52 & 2,11 & 2,67 \\
\hline
\end{tabular}

*: dp = desvio padrão; $\mathrm{LI}$ = limite inferior e LS = limite superior

Os desvios padrão demonstram a heterogeneidade dos valores em relação à média (Tabela 9). Não houve diferença estatística em nível de $5 \%$ de significância entre os CPODs médios registrados para os grupos de escolas (Teste Kruskal-Wallis; $p=0,084$ ).

Por outro lado, por meio dos dados referentes à composição do índice (Tabelas 8 e 9), fica claro que há uma variação do número médio de dentes CPO de acordo com o tipo de escola, ou seja, não houve diferenças na média final, mas as composições são diferentes (Figura 4).

Figura 4 - Número médio de dentes cariados, perdidos e obturados em escolares aos doze anos de idade, segundo componentes $e$ tipo de escola. Feira de Santana - BA, zona urbana, 2002.

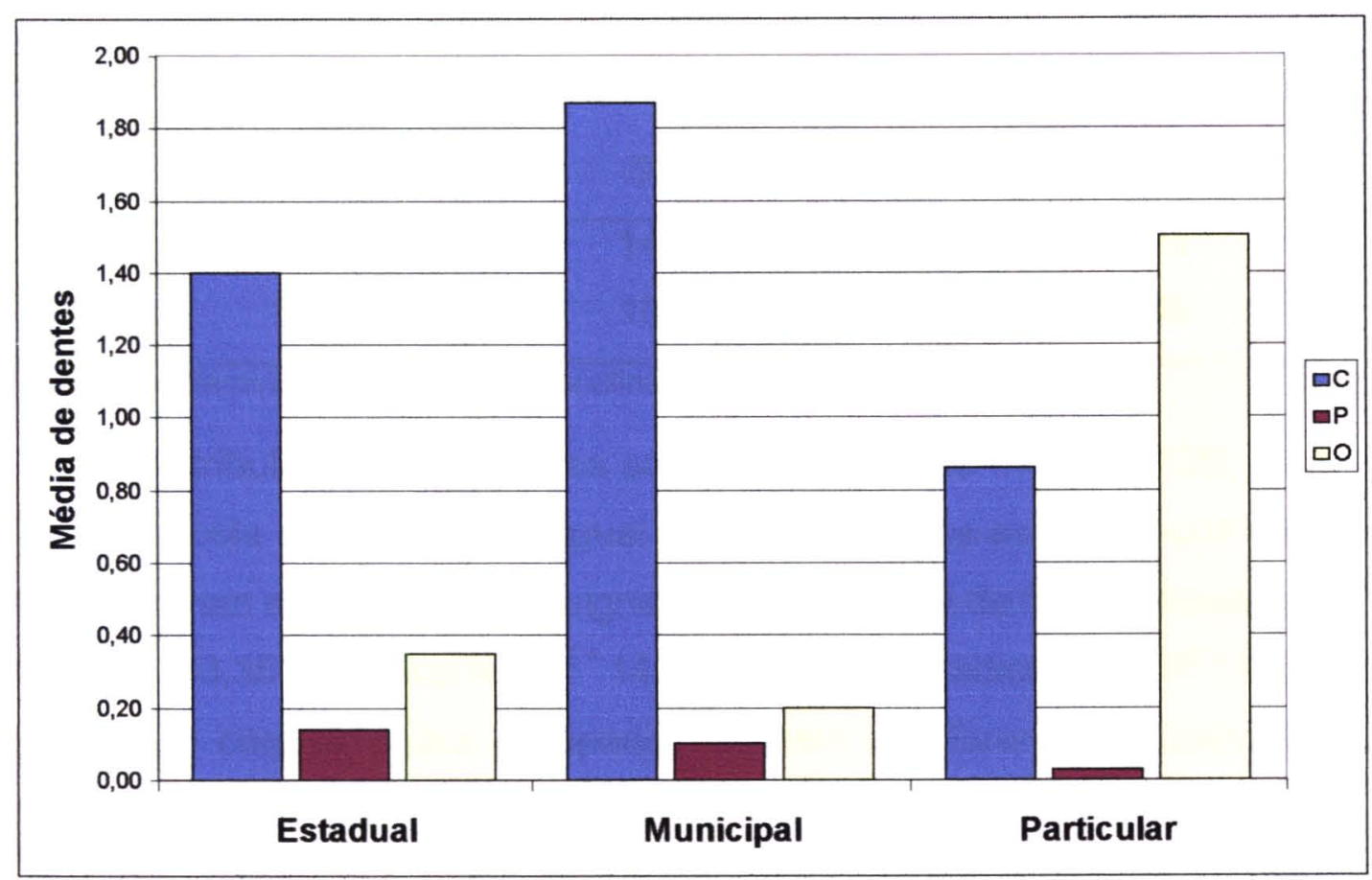


As comparações entre os valores de CPOD segundo sexo e tipo de escola (estaduais, municipais e particulares) não se constituíram significativas em nivel de $5 \%\left(X^{2}=6,18 / p=0,403 ; X^{2}=9,97 / p=0,126\right.$ e $X^{2}=7,67 / p=0,263$, respectivamente) (Tabela 10).

Tabela 10 - Distribuição do número e percentual dos escolares de doze anos segundo valores do indice CPOD, sexo e tipo de escola. Feira de Santana - BA, zona urbana, 2002.

\begin{tabular}{|c|c|c|c|c|c|c|c|}
\hline \multirow{2}{*}{\multicolumn{2}{|c|}{ Valor do CPOD }} & \multicolumn{2}{|c|}{ Estadual } & \multicolumn{2}{|c|}{ Municipal } & \multicolumn{2}{|c|}{ Particular } \\
\hline & & $F^{*}$ & $\overline{\mathbf{M}^{*}}$ & $\mathbf{F}$ & $\bar{M}$ & $\bar{F}$ & $\mathbf{M}$ \\
\hline \multirow[t]{2}{*}{0} & № & 56 & 57 & 65 & 63 & 53 & $\overline{56}$ \\
\hline & $\%$ & 32,7 & 38,8 & 39,9 & 36,8 & 29,6 & 40,0 \\
\hline \multirow[t]{2}{*}{1} & № & 34 & 30 & 18 & 27 & 28 & 11 \\
\hline & $\%$ & 19,9 & 20,4 & 11,0 & 15,8 & 15,6 & 7,9 \\
\hline \multirow[t]{2}{*}{2} & № & 25 & 14 & 14 & 30 & 21 & 17 \\
\hline & $\%$ & 14,6 & 9,5 & 8,6 & 17,5 & 11,7 & 12,1 \\
\hline \multirow[t]{2}{*}{3} & № & 19 & 14 & 19 & 14 & 16 & 15 \\
\hline & $\%$ & 11,1 & 9,5 & 11,7 & 8,2 & 8,9 & 10,7 \\
\hline \multirow[t]{2}{*}{4} & № & 16 & 21 & 19 & 12 & 23 & 18 \\
\hline & $\%$ & 9,4 & 14,3 & 11,7 & 7,0 & 12,8 & 12,9 \\
\hline \multirow[t]{2}{*}{5} & № & 5 & 3 & 9 & 8 & 18 & 10 \\
\hline & $\%$ & 2,9 & 2,0 & 5,5 & 4,7 & 10,1 & 7,1 \\
\hline \multirow[t]{2}{*}{$6-17$} & № & 16 & 8 & 19 & 17 & 20 & 13 \\
\hline & $\%$ & 9,4 & 5,4 & 11,7 & 9,9 & 11,2 & 9,3 \\
\hline \multirow[t]{2}{*}{ Total } & No & 171 & 147 & 163 & 171 & 179 & 140 \\
\hline & $\%$ & 100 & 100 & 100 & 100 & 100 & 100 \\
\hline
\end{tabular}

«: $F=$ Sexo feminino e $M=$ Sexo masculino.

A distribuição dos escolares segundo valores do índice CPOD, etnia e tipo de escola se mostrou desigual (Tabela 11), mas as diferenças não se apresentaram estatisticamente significativas em nivel de $5 \%$, (Estaduais: $X^{2}=$ $13,25 / p=0,351$; Municipais: $X^{2}=14,95 / p=0,244$; Particulares: $X^{2}=10,94 / p$ $=0,534$ ) e com os dados agrupados também não foram diferentes (Teste Kruskal-Wallis; $p=0,446$ ). 
Tabela 11 - Distribuição do número e percentual dos escolares de doze anos examinados segundo valores do índice CPOD, etnia e tipo de escola. Feira de Santana - BA, zona urbana, 2002.

\begin{tabular}{|c|c|c|c|c|c|c|c|c|c|c|}
\hline \multirow{2}{*}{\multicolumn{2}{|c|}{$\begin{array}{l}\text { Valor do } \\
\text { CPOD }\end{array}$}} & \multicolumn{3}{|c|}{ Estadual } & \multicolumn{3}{|c|}{ Municipal } & \multicolumn{3}{|c|}{ Particular } \\
\hline & & \multirow{2}{*}{$\begin{array}{r}P^{*} \\
42\end{array}$} & \multirow{2}{*}{$\begin{array}{r}\mathbf{N}^{*} \\
64\end{array}$} & \multirow{2}{*}{$\frac{\mathrm{B}^{*}}{7}$} & \multirow{2}{*}{$\begin{array}{l}P \\
55\end{array}$} & \multirow{2}{*}{$\begin{array}{l}\mathbf{N} \\
67\end{array}$} & \multirow{2}{*}{$\frac{\mathrm{B}}{6}$} & \multirow{2}{*}{$\begin{array}{l} \\
49\end{array}$} & \multirow{2}{*}{$\frac{\mathbf{N}}{15}$} & \multirow{2}{*}{$\frac{B}{45}$} \\
\hline 0 & № & & & & & & & & & \\
\hline & $\%$ & 32,8 & 37,6 & 35,0 & 41,0 & 37,2 & 30,0 & 33,1 & 31,9 & 36,3 \\
\hline \multirow[t]{2}{*}{1} & № & 23 & 39 & 2 & 12 & 29 & 4 & 20 & 4 & 15 \\
\hline & $\%$ & 18,0 & 22,9 & 10,0 & 9,0 & 16,1 & 20,0 & 13,5 & 8,5 & 12,1 \\
\hline \multirow[t]{2}{*}{2} & № & 18 & 19 & 2 & 19 & 21 & 4 & 22 & 5 & 11 \\
\hline & $\%$ & 14,1 & 11,2 & 10,0 & 14,2 & 11,7 & 20,0 & 14,9 & 10,6 & 8,9 \\
\hline \multirow[t]{2}{*}{3} & № & 19 & 10 & 4 & 11 & 21 & 1 & 12 & 8 & 11 \\
\hline & $\%$ & 14,8 & 5,9 & 20,0 & 8,2 & 11,7 & 5,0 & 8,1 & 17,0 & 8,9 \\
\hline \multirow[t]{2}{*}{4} & № & 16 & 18 & 3 & 18 & 11 & 2 & 15 & 7 & 19 \\
\hline & $\%$ & 12,5 & 10,6 & 15,0 & 13,4 & 6,1 & 10,0 & 10,1 & 14,9 & 15,3 \\
\hline \multirow[t]{2}{*}{5} & № & 2 & 6 & - & 9 & 7 & 1 & 12 & 6 & 10 \\
\hline & $\%$ & 1,6 & 3,5 & - & 6,7 & 3,9 & 5,0 & 8,1 & 12,8 & 8,1 \\
\hline \multirow[t]{2}{*}{$6-17$} & № & 8 & 14 & 2 & 10 & 24 & 2 & 18 & 2 & 13 \\
\hline & $\%$ & 6,3 & 8,2 & 10,0 & 7,5 & 13,3 & 10,0 & 12,2 & 4,3 & 10,5 \\
\hline \multirow[t]{2}{*}{ Total } & No & 128 & 170 & 20 & 134 & 180 & 20 & 148 & 47 & 124 \\
\hline & $\%$ & 100 & 100 & 100 & 100 & 100 & 100 & 100 & 100 & 100 \\
\hline
\end{tabular}

${ }^{*}: \mathrm{P}=$ Parda, $\mathrm{N}=$ Negra e $\mathrm{B}=$ Branca.

Com relação às necessidades de tratamento, foi observado que um percentual maior de escolares sem necessidade de tratamento nas escolas particulares $(44,2 \%)$ do que nas escolas municipais $(31,4 \%)$ e estaduais $(30,5 \%)$. Sobre o total de dentes examinados os resultados estão apresentados nas tabelas 12 e 13.

Em todos os tipos de escola mais de $90,0 \%$ dos dentes dos escolares não apresentaram necessidades de tratamento; sendo que nas escolas particulares somente em 5,6\% houve necessidades, percentual este bem menor que aqueles observados nas escolas municipais e estaduais. 
Tabela 12 - Distribuição do número e percentual de dentes segundo necessidades de tratamento e tipo de escola em escolares de doze anos de idade. Feira de Santana - BA, zona urbana, 2002.

\begin{tabular}{lcccccccc}
\hline Necessidade de & \multicolumn{2}{c}{ Estadual } & \multicolumn{2}{c}{ Municipal } & \multicolumn{2}{c}{ Particular } & \multicolumn{2}{c}{ Total } \\
\cline { 2 - 9 } Tratamento & \multicolumn{1}{c}{$\mathbf{D}^{*}$} & $\%$ & $\mathbf{D}$ & $\%$ & $\mathbf{D}$ & $\%$ & $\mathbf{D}$ & $\%$ \\
\hline S/ Necessidade & 8.217 & 92,3 & 8.502 & 91,0 & 8.435 & 94,4 & 25.154 & 92,5 \\
C/ Necessidade & 687 & 7,7 & 850 & 9,0 & 497 & 5,6 & 2.034 & 7,5 \\
\hline Total & $\mathbf{8 . 9 0 4}$ & $\mathbf{1 0 0}$ & $\mathbf{9 . 3 5 2}$ & $\mathbf{1 0 0}$ & $\mathbf{8 . 9 3 2}$ & $\mathbf{1 0 0}$ & $\mathbf{2 7 . 1 8 8}$ & $\mathbf{1 0 0}$ \\
\hline
\end{tabular}

$\overline{{ }^{\prime}: \mathrm{D}=\text { dentes. }}$.

Dentre os dentes que requeriam tratamento, apenas o uso de selante foi indicado como ação preventiva (Tabela 13), o qual mostrou diferença significativa em nivel de $5 \%$ entre os tipos de escola $\left(X^{2}=19,56 ; p=0,034\right)$.

Tabela 13 - Distribuição do número e percentual de dentes segundo tipo de necessidade de tratamento e escola, em escolares de doze anos de idade. Feira de Santana - BA, zona urbana, 2002.

\begin{tabular}{lcccccccc}
\hline \multirow{2}{*}{$\begin{array}{c}\text { Tipo de } \\
\text { Necessidade }\end{array}$} & \multicolumn{2}{c}{ Estadual } & \multicolumn{2}{c}{ Municipal } & \multicolumn{2}{c}{ Particular } & \multicolumn{2}{c}{ Total } \\
\cline { 2 - 9 } & $\mathbf{D}^{*}$ & $\%$ & $\mathbf{D}$ & $\%$ & $\mathbf{D}$ & $\%$ & $\mathbf{D}$ & $\%$ \\
\hline Açōes Preventivas & & & & & & & & \\
Selante & 215 & 31,3 & 209 & 24,6 & 212 & 42,7 & 636 & 31,3 \\
\hline Ações Curativas & & & & & & & & \\
Rest. de 1 sup. & 249 & 36,2 & 344 & 40,5 & 190 & 38,2 & 783 & 38,5 \\
Rest. de 2 ou + sup. & 137 & 20,0 & 194 & 22,8 & 77 & 15,5 & 408 & 20,0 \\
Extração & 25 & 3,6 & 39 & 4,6 & 5 & 1,0 & 69 & 3,4 \\
Trat. Pulpar + rest. & 55 & 8,0 & 58 & 6,8 & 11 & 2,2 & 124 & 6,1 \\
$\quad$ Coroa & 6 & 0,9 & 6 & 0,7 & 2 & 0,4 & 14 & 0,7 \\
\hline Total & $\mathbf{6 8 7}$ & $\mathbf{1 0 0}$ & $\mathbf{8 5 0}$ & $\mathbf{1 0 0}$ & $\mathbf{4 9 7}$ & $\mathbf{1 0 0}$ & $\mathbf{2 . 0 3 4}$ & $\mathbf{1 0 0}$ \\
\hline
\end{tabular}

$\bar{\pi} \mathrm{D}=$ dentes.

Quanto às ações curativas, houve uma tendência decrescente das necessidades à medida que o tratamento indicado era mais complexo. Entre os tipos de necessidades, restauração de uma superficie, restauração de duas ou mais superfícies, extração, tratamento pulpar/restauração e dos tipos de escolas as diferenças foram significativas $\left(X^{2}=48,32 / p=0,000 ; X^{2}\right.$ 
$=32,51 / p=0,003 ; X^{2}=16,80 / p=0,032$ e $X^{2}=34,15 / p=0,000$, respectivamente) exceto para a indicação de coroa $\left(X^{2}=3,98 / p=0,408\right)$. Vale ressaltar que entre as indicações curativas foi maior a necessidade de extrações e tratamento pulpar/restaurador nas escolas estaduais e municipais que nas particulares.

\subsection{DOENÇA PERIODONTAL}

A tabela 14 apresenta os dados de prevalência da doença periodontal das crianças examinadas segundo tipo de escola.

Tabela 14 - Distribuição do número e percentual de escolares de doze anos segundo a pior condição periodontal encontrada por indivíduo e tipo de escola. Feira de Santana - BA, zona urbana, 2002.

\begin{tabular}{ccccccc}
\hline Condição & \multicolumn{2}{c}{ Estadual } & \multicolumn{2}{c}{ Municipal } & \multicolumn{2}{c}{ Particular } \\
\cline { 2 - 7 } Periodontal & No & $\%$ & No & $\%$ & No & $\%$ \\
\hline 0 (Sadios) & 100 & 31,4 & 80 & 24,0 & 173 & 54,2 \\
$\mathbf{1}$ (Sangramento) & 65 & 20,4 & 72 & 21,6 & 86 & 27,0 \\
$\mathbf{2}$ (Cálculo) & 153 & 48,1 & 182 & 54,5 & 60 & 18,8 \\
\hline Total & $\mathbf{3 1 8}$ & $\mathbf{1 0 0}$ & $\mathbf{3 3 4}$ & $\mathbf{1 0 0}$ & $\mathbf{3 1 9}$ & $\mathbf{1 0 0}$ \\
\hline
\end{tabular}

A distribuição dos escolares entre as condições periodontais demonstrou diferença estatística em nível de $5 \%\left(X^{2}=105,16 ; p=0,000\right)$ e comportamento inverso entre as escolas públicas e particulares. Nas primeiras houve uma tendência crescente do percentual de escolares à medida que foram registradas piores condições periodontais enquanto que nas privadas a tendência foi decrescente, sendo observada em mais da metade da amostra a condição "sadio" $(54,2 \%)$

Quanto à extensão das doenças periodontais os dados estão apresentados nas tabelas $15,16,17$ e 18. 
Tabela 15 - Distribuição do número e percentual de escolares de doze anos de idade segundo condições periodontais, sexo e tipo de escola. Feira de Santana - BA, zona urbana, 2002.

\begin{tabular}{|c|c|c|c|c|c|c|c|}
\hline \multirow{2}{*}{$\begin{array}{c}\text { Condição } \\
\text { Periodontal }\end{array}$} & & \multicolumn{2}{|c|}{$\overline{\text { Estadual }}$} & \multicolumn{2}{|c|}{ Municipal } & \multicolumn{2}{|c|}{ Particular } \\
\hline & & $F^{*}$ & $\mathbf{M}^{*}$ & $\bar{F}$ & $\mathbf{M}$ & $\bar{F}$ & $\bar{M}$ \\
\hline \multirow[t]{2}{*}{0 (Sadios) } & № & 63 & 37 & 48 & 32 & 102 & 71 \\
\hline & $\%$ & 36,8 & 25,2 & 29,4 & 18,7 & 57,0 & 50,7 \\
\hline \multirow[t]{2}{*}{1 (Sangramento) } & № & 32 & 33 & 39 & 33 & 45 & 41 \\
\hline & $\%$ & 18,7 & 22,4 & 23,9 & 19,3 & 25,1 & 29,3 \\
\hline \multirow[t]{2}{*}{2 (Cálculo) } & № & 76 & 77 & 76 & 106 & 32 & 28 \\
\hline & $\%$ & 44,4 & 52,4 & 46,6 & 62,0 & 17,9 & 20,0 \\
\hline \multirow[t]{2}{*}{ Total } & № & 171 & 147 & 163 & 171 & 179 & $\overline{140}$ \\
\hline & $\%$ & 100 & 100 & 100 & 100 & 100 & 100 \\
\hline
\end{tabular}

*:F = Sexo feminino e $M=$ Sexo masculino.

Ao analisar os dados segundo o sexo, verificou-se que independente do tipo de escola, nos escolares examinados houve uma menor prevalência da condição "sadio" e maior prevalência da condição "cálculo" para o sexo masculino. Esta diferença foi estatisticamente significativa em nível de $5 \%$ $\left(X^{2}=8,45 ; p=0,015\right)$ nas escolas municipais, registrando, portanto, uma condição de saúde periodontal mais favorável no sexo feminino neste tipo de escola, o que não ocorreu nas estaduais $\left(X^{2}=4,99 ; p=0,082\right)$ e particulares $\left(X^{2}=1,25 ; p=0,533\right)$.

Os dados das condições periodontais segundo os grupo étnicos exibiram na condição "sadio" os maiores percentuais no grupo "brancos", seguido dos grupos "pardos" e "negros", independente do tipo de escola. $\mathrm{Na}$ condição "sangramento" os percentuais foram semelhantes entre os grupos étnicos, exceto para "negros" nas escolas particulares. Ao passo que a condição "cálculo" foi maior em "negros" nas escolas estaduais $(54,1 \%)$ e municipais $(60,0 \%)$ e em "brancos" nas particulares $(21,0 \%)$. Quando a análise estatística foi feita sem a distribuição por tipo de escola houve diferença em nivel de $5 \%\left(X^{2}=53,38 ; p=0,000\right)$. No entanto quando se analisou por tipo de escola a diferença não se confirmou (Estaduais: $X^{2}=$ 
$7,64 / p=0,105 ;$ Municipais: $X^{2}=9,17 / p=0,057$ e Particulares: $X^{2}=2,29 / p=$ 0,682 ) (Tabela 16).

Tabela 16 - Distribuição do número e percentual de escolares de doze anos de idade segundo condições periodontais, etnia e tipo de escola. Feira de Santana -BA, zona urbana, 2002.

\begin{tabular}{|c|c|c|c|c|c|c|c|c|c|c|}
\hline \multirow{2}{*}{$\begin{array}{l}\text { Condição } \\
\text { Periodontal }\end{array}$} & & \multicolumn{3}{|c|}{ Estadual } & \multicolumn{3}{|c|}{ Municipal } & \multicolumn{3}{|c|}{ Particular } \\
\hline & & $\mathbf{P}^{*}$ & $\mathbf{N}^{*}$ & $\mathrm{~B}^{*}$ & $\mathbf{P}$ & $\overline{\mathbf{N}}$ & $\bar{B}$ & $\mathbf{P}$ & $\mathbf{N}$ & $\bar{B}$ \\
\hline \multirow[t]{2}{*}{0 (Sadios) } & № & 45 & 15 & 10 & 33 & 38 & 9 & 81 & 23 & 6 \\
\hline & $\%$ & 35,2 & 26,5 & 50,0 & 24,6 & 21,1 & 45,0 & 54,7 & 48,9 & 55 \\
\hline \multirow[t]{2}{*}{1 (Sangramento) } & № & 28 & 3 & 4 & 3 & 4 & 5 & 1 & 16 & 2 \\
\hline & $\%$ & 21,9 & 19,4 & 20,0 & 24,6 & 18,9 & 25,0 & 27,7 & 34,0 & 23 \\
\hline \multirow[t]{2}{*}{2 (Cálculo) } & № & 55 & 92 & 6 & 68 & 108 & 6 & 26 & 8 & 2 \\
\hline & $\%$ & 43,0 & 54,1 & 30,0 & 50,7 & 60,0 & 30,0 & 17,6 & 17,0 & 21,0 \\
\hline \multirow[t]{2}{*}{ Total } & № & 128 & 70 & 20 & 134 & 180 & 20 & 148 & 47 & 12 \\
\hline & $\%$ & 100 & 100 & 100 & 100 & 100 & 100 & 100 & 100 & 100 \\
\hline
\end{tabular}

*:P $=$ Parda, $\mathrm{N}=$ Negra e $\mathrm{B}=$ Branca.

Dentre o número de sextantes examinados, a condição "sadio" predominou em todos os tipos de escola: estaduais $(72,7 \%)$, municipais $(68,0 \%)$ e particulares $(86,0 \%)$ (Tabela 17 ).

Tabela 17 - Distribuição do número e percentual de sextantes examinados em escolares de doze anos de idade segundo condição periodontal e tipo de escola. Feira de Santana - BA, zona urbana, 2002.

\begin{tabular}{ccccccccc}
\hline Condição & \multicolumn{2}{c}{ Estadual } & \multicolumn{2}{c}{ Municipal } & \multicolumn{2}{c}{ Particular } & \multicolumn{2}{c}{ Total } \\
\cline { 2 - 9 } Periodontal & $\mathbf{S}^{*}$ & $\%$ & $\mathbf{S}$ & $\mathbf{\%}$ & $\mathbf{S}$ & $\%$ & $\mathbf{S}$ & $\%$ \\
\hline $\mathbf{0}$ (Sadios) & 1.387 & 72,7 & 1.362 & 68,0 & 1,646 & 86,0 & 4.395 & 75,4 \\
$\mathbf{1}$ (Sangramento) & 203 & 10,6 & 227 & 11,3 & 151 & 7,9 & 581 & 10,0 \\
$\mathbf{2}$ (Cálculo) & 318 & 16,7 & 394 & 19,7 & 97 & 5,1 & 809 & 13,9 \\
$\mathbf{X}$ (Nulo) & - & - & 21 & 1,0 & 20 & 1,0 & 41 & 0,7 \\
\hline Total & $\mathbf{1 9 0 8}$ & $\mathbf{1 0 0}$ & $\mathbf{2 0 0 4}$ & $\mathbf{1 0 0}$ & $\mathbf{1 9 1 4}$ & $\mathbf{1 0 0}$ & $\mathbf{5 . 8 2 6}$ & $\mathbf{1 0 0}$ \\
\hline
\end{tabular}

*:S $=$ Sextantes. 
Tabela 18 - Distribuição percentual de sextantes examinados segundo condição periodontal e sextantes superiores e inferiores. Feira de Santana - BA, zona urbana, 2002.

\begin{tabular}{|c|c|c|c|c|c|c|}
\hline \multirow{3}{*}{$\begin{array}{l}\text { Condição } \\
\text { Periodontal }\end{array}$} & \multicolumn{6}{|c|}{ Sextantes* } \\
\hline & \multicolumn{3}{|c|}{ Superiores } & \multicolumn{3}{|c|}{ Inferiores } \\
\hline & $\bar{D}$ & C & $\bar{E}$ & $\bar{D}$ & C & $\bar{E}$ \\
\hline 0 (Sadios) & 68,0 & 89,8 & 64,0 & 79,9 & 76,6 & $\overline{74,4}$ \\
\hline 1 (Sangramento) & 15,3 & 7,4 & 18,0 & 8,3 & 6,4 & 4,5 \\
\hline 2 (Cálculo) & 16,0 & 2,3 & 17,0 & 11,0 & 16,5 & 20,5 \\
\hline$X$ (Nulo) & 0,7 & 0,5 & 1,0 & 0,8 & 0,5 & 0,6 \\
\hline Total & 100 & 100 & 100 & 100 & 100 & 100 \\
\hline
\end{tabular}

\#:D = direito, $C=$ central e $E=$ esquerdo.

Ao analisar os resultados por sextante, concluiu-se que o sextante central superior foi o que apresentou o maior percentual da condição "sadio" (90,3 \%). A condição "sangramento" foi registrada com maiores freqüências nos sextantes esquerdo e direito superiores. Mas na condição "cálculo" o maior valor $(20,5 \%)$ foi identificado no sextante esquerdo inferior (Tabela 18).

Quanto a severidade, os dados se encontram apresentados nas tabelas 19 e 20.

Tabela 19 - Distribuição do número e média de sextantes examinados em escolares de doze anos de idade segundo condição periodontal e tipo de escola. Feira de Santana - BA, zona urbana, 2002.

\begin{tabular}{ccccccc}
\hline Condição & \multicolumn{2}{c}{ Estadual } & \multicolumn{2}{c}{ Municipal } & \multicolumn{2}{c}{ Particular } \\
\cline { 2 - 7 } Periodontal & $\mathbf{N}^{\mathbf{0}}$ & Média & No & Média & $\mathbf{N}^{\mathbf{0}}$ & Média \\
\hline $\mathbf{0}$ (Sadios) & 1.387 & 4,36 & 1.362 & $\mathbf{4 , 0 8}$ & 1.646 & 5,16 \\
$\mathbf{1}$ (Sangramento) & 203 & 0,64 & 227 & 0,68 & 151 & 0,47 \\
$\mathbf{2}$ (Cálculo) & 318 & 1,00 & 394 & 1,18 & 97 & 0,30 \\
X (Nulo) & - & - & 21 & 0,06 & 20 & 0,07 \\
\hline Total & $\mathbf{1 . 9 0 8}$ & $\mathbf{6 , 0 0}$ & $\mathbf{2 . 0 0 4}$ & $\mathbf{6 , 0 0}$ & $\mathbf{1 . 9 1 4}$ & $\mathbf{6 , 0 0}$ \\
\hline
\end{tabular}


A distribuição das médias não foi homogênea. Houve uma média maior de sextantes sadios e médias menores de sextantes com sangramento e cálculo nas escolas particulares (Tabela 19). As médias de sextantes em cada condição periodontal por tipo de escola apresentaram diferenças significativas em nivel de $5 \%$ (Anova, $p=0,000 ; p=0,009 ; p=0,000$, respectivamente). Isto demonstrou condiçōes de saúde periodontal mais favoráveis nos escolares de instituições particulares.

Tabela 20 - Distribuição do número e percentual de escolares de doze anos de idade segundo o número de sextantes sadios por indivíduo e tipo de escola. Feira de Santana - BA, zona urbana, 2002.

\begin{tabular}{ccccccc}
\hline Sextantes Sadios & \multicolumn{2}{c}{ Estadual } & \multicolumn{2}{c}{ Municipal } & \multicolumn{2}{c}{ Particular } \\
\cline { 2 - 7 } & No & $\%$ & No $^{\circ}$ & $\%$ & № & $\%$ \\
\hline $\mathbf{6}$ & 100 & 31,4 & 80 & 24,0 & 171 & 53,6 \\
$\mathbf{5}$ & 75 & 23,6 & 78 & 23,4 & 83 & 26,0 \\
$\mathbf{4}$ & 59 & 18,6 & 64 & 19,2 & 40 & 12,5 \\
$\mathbf{3}$ & 33 & 10,4 & 53 & 15,9 & 12 & 3,8 \\
$\mathbf{2}$ & 34 & 10,7 & 40 & 12,0 & 9 & 2,8 \\
$\mathbf{1}$ & 9 & 2,8 & 15 & 4,5 & 3 & 0,9 \\
$\mathbf{0}$ & 8 & 2,5 & 4 & 1,2 & 1 & 0,3 \\
\hline Total & $\mathbf{3 1 8}$ & $\mathbf{1 0 0}$ & $\mathbf{3 3 4}$ & $\mathbf{1 0 0}$ & $\mathbf{3 1 9}$ & $\mathbf{1 0 0}$ \\
\hline
\end{tabular}

Observou-se uma tendência decrescente da distribuição à medida que diminuía a freqüência de sextantes sadios por indivíduo. Quanto ao tipo de escola, nas particulares em mais da metade da distribuição os escolares possuíam todos os sextantes sadios, nas estaduais um terço e nas municipais menos de um quarto. Com respeito a não possuir nenhum sextante sadio o maior percentual ocorreu nas estaduais, em seguida nas municipais e particulares. Esta distribuição confirma novamente uma menor severidade das condições periodontais nas escolas particulares (Tabela 20).

Foi verificada a correlação entre a prevalência do CPOD e o $\mathrm{CPI}$ constatando-se que não houve significância ao nivel de $5 \%$ (Coef. de Correlação de Spearman $r=0,003 ; p=0,937$ ). Também foi pesquisada a correlação entre o CPOD e a condição "sangramento", a qual não mostrou significância estatística (Coef. de Correlação de Spearman $r=0,028 ; p=$ $0,389)$. 


\subsection{OCLUSOPATIAS}

No capítulo de Material e Métodos foi descrito que escolares que ainda estivessem na fase de dentição mista não fariam parte da amostra para oclusopatia, portanto após a exclusão destes escolares o tamanho da amostra para o cálculo do DAl foi igual a 732. As distribuições amostrais, segundo sexo e etnia, estão representadas a seguir (Tabelas 21 e 22) .

Tabela 21 - Distribuição do número e percentual dos escolares de doze anos examinados para o cálculo do DAl segundo sexo e tipo de escola. Feira de Santana - BA, zona urbana, 2002.

\begin{tabular}{ccccccc}
\hline \multirow{2}{*}{ Sexo } & \multicolumn{2}{c}{ Estadual } & \multicolumn{2}{c}{ Municipal } & \multicolumn{2}{c}{ Particular } \\
\cline { 2 - 7 } & № & $\%$ & № & $\%$ & № & $\%$ \\
\hline Feminino & 138 & 57,7 & 126 & 52,7 & 142 & 55,9 \\
Masculino & 101 & 42,3 & 113 & 47,3 & 112 & 44,1 \\
\hline Total & $\mathbf{2 3 9}$ & $\mathbf{1 0 0}$ & $\mathbf{2 3 9}$ & $\mathbf{1 0 0}$ & $\mathbf{2 5 4}$ & $\mathbf{1 0 0}$ \\
\hline
\end{tabular}

A distribuição segundo sexo mostrou ligeiro predomínio do sexo feminino e foi similar entre os tipos de escola, não apresentando diferença estatística em nivel de $5 \%\left(X^{2}=1,25 ; p=0,535\right)$.

Tabela 22 - Distribuição do número e percentual dos escolares de doze anos examinados para o cálculo do DAl segundo etnia e tipo de escola. Feira de Santana - BA, zona urbana, 2002.

\begin{tabular}{ccccccc}
\hline Etnia & \multicolumn{2}{c}{ Estadual } & \multicolumn{2}{c}{ Municipal } & \multicolumn{2}{c}{ Particular } \\
\cline { 2 - 7 } & № & $\%$ & № & $\%$ & № & $\%$ \\
\hline "Parda" & 92 & 38,5 & 90 & 37,7 & 95 & 37,4 \\
"Negra" & 130 & 54,4 & 135 & 56,5 & 37 & 14,6 \\
"Branca" & 17 & 7,1 & 14 & 5,9 & 122 & 48,0 \\
\hline Total & $\mathbf{2 3 9}$ & $\mathbf{1 0 0}$ & $\mathbf{2 3 9}$ & $\mathbf{1 0 0}$ & $\mathbf{2 5 4}$ & $\mathbf{1 0 0}$ \\
\hline
\end{tabular}

A distribuição dos escolares segundo etnia exibiu comportamento semelhante entre as escolas estaduais e municipais com predominio de "negros", e diferente entre estas escolas e as particulares que apresentou um predomínio de "brancos". No grupo "pardos" os percentuais são 
equilibrados entre os três tipos de escola. As diferenças observadas foram estatisticamente significativas $\left(X^{2}=163,47 ; p=0,000\right)$ (Tabela 22).

A tabela 23 apresenta a distribuição da frequência de escolares segundo os graus de oclusopatia.

Tabela 23 - Distribuição do número e percentual de escolares de doze anos de idade segundo o grau de oclusopatia (DAI) e o tipo de escola. Feira de Santana - BA, zona urbana, 2002.

\begin{tabular}{ccccccc}
\hline Grau de & \multicolumn{2}{c}{ Estadual } & \multicolumn{2}{c}{ Municipal } & \multicolumn{2}{c}{ Particular } \\
\cline { 2 - 7 } Oclusopatia & No & $\%$ & № & $\%$ & № & $\%$ \\
\hline Normal & 107 & 44,8 & 125 & 52,3 & 132 & 52,0 \\
Definida & 61 & 25,5 & 58 & 24,3 & 71 & 28,0 \\
Severa & 34 & 14,2 & 18 & 7,5 & 26 & 10,2 \\
Incapacitante & 37 & 15,5 & 38 & 15,9 & 25 & 9,8 \\
\hline Total & $\mathbf{2 3 9}$ & $\mathbf{1 0 0}$ & $\mathbf{2 3 9}$ & $\mathbf{1 0 0}$ & $\mathbf{2 5 4}$ & $\mathbf{1 0 0}$ \\
\hline
\end{tabular}

A maioria das crianças das escolas municipais e particulares apresentou grau de oclusão "normal". No grau "incapacitante" foi observada uma maior freqüência nas escolas públicas em relação às particulares (Tabela 23). No entanto, as diferenças registradas não foram estatisticamente significativas em nivel de $5 \%\left(X^{2}=11,68 ; p=0,069\right)$.

As tabelas 24, 25, 26 e 27 mostram a distribuição dos escolares segundo condições do Indice Estético Dentário.

Tabela 24 - Distribuição do número e percentual de escolares de doze anos de idade segundo o grupo de condição dentição e o tipo de escola. Feira de Santana - BA, zona urbana, 2002.

\begin{tabular}{crrrrrrr}
\hline Condição & \multicolumn{2}{c}{ Estadual } & \multicolumn{2}{c}{ Municipal } & \multicolumn{2}{c}{ Particular } \\
\cline { 2 - 8 } Dentição* & \multicolumn{3}{c}{ Ausente Presente } & Ausente Presente & Ausente Presente \\
\hline Perda dental superior & $^{0}$ & 238 & 1 & 237 & 2 & 251 & 3 \\
& $\%$ & 99,6 & 0,4 & 99,2 & 0,8 & 98,8 & 1,2 \\
Perda dental inferior & $N^{0}$ & 239 & - & 239 & - & 252 & 2 \\
& $\%$ & 100 & - & 100 & - & 99,2 & 0,8 \\
\hline
\end{tabular}

*: Número de dentes incisivos, caninos e pré-molares permanentes perdidos. 
Destaca-se em todos os tipos de escola a perda pouco expressiva de elementos dentários anteriores. Não havendo diferenças significativas entre as escolas $\left(X^{2}=2,25 ; p=0,689\right.$ e $X^{2}=3,77 ; p=0,437$ ) (Tabela 24).

Tabela 25 - Distribuição do número e percentual de escolares de doze anos de idade segundo o grupo de condição espaço e o tipo de escola. Feira de Santana - BA, zona urbana, 2002.

\begin{tabular}{lrrrrrrr}
\hline \multirow{2}{*}{$\begin{array}{c}\text { Condição } \\
\text { Espaço }\end{array}$} & \multicolumn{3}{c}{ Estadual } & \multicolumn{2}{c}{ Municipal } & \multicolumn{2}{c}{ Particular } \\
\cline { 2 - 8 } & Ausente & Presente & Ausente & Presente & Ausente & Presente \\
\hline Apinhamento & № & 155 & 84 & 135 & 104 & 126 & 128 \\
& $\%$ & 64,9 & 35,1 & 56,5 & 43,5 & 49,6 & 50,4 \\
Espaçamento & $№$ & 142 & 97 & 159 & 80 & 160 & 94 \\
& $\%$ & 59,4 & 40,6 & 66,5 & 33,5 & 63,0 & 37,0 \\
Diastema & $№$ & 181 & 58 & 199 & 40 & 212 & 42 \\
& $\%$ & 75,7 & 24,3 & 83,3 & 16,7 & 83,5 & 16,5 \\
Desalinham. Maxilar & $№$ & 183 & 56 & 178 & 61 & 198 & 56 \\
& $\%$ & 76,6 & 23,4 & 74,5 & 25,5 & 78,0 & 22,0 \\
Desalinham. Mand. & № & 182 & 57 & 183 & 56 & 187 & 67 \\
& $\%$ & 76,2 & 23,8 & 76,6 & 23,4 & 73,6 & 26,4 \\
\hline
\end{tabular}

O apinhamento apresentou maior prevalência nas escolas particulares $(50,4 \%)$ e entre os tipos de escola houve diferença estatisticamente significativa em nivel de $5 \%\left(X^{2}=16,76 ; p=0,002\right)$. O espaçamento foi mais prevalente nas escolas estaduais, apresentando diferença estatística $\left(X^{2}=\right.$ $10,07 ; p=0,039)$. A presença de diastema também foi mais prevalente nas escolas estaduais, mas não mostrou diferença estatística em nível de $5 \%$ ( $X^{2}$ $=10,80 ; p=0,213)$. O desalinhamento maxilar e mandibular exibiram percentuais semelhantes entre os tipos de escola, não apresentando diferenças estatisticas $\left(X^{2}=6,78 ; p=0,871\right.$ e $X^{2}=10,41 ; p=0,405$, respectivamente). Os resultados das três primeiras caracteristicas sugerem uma condição de espaço possivelmente mais favorável à oclusão nas escolas estaduais (Tabela 25). 
Tabela 26 - Distribuição do número e percentual de escolares de doze anos de idade segundo o grupo de condição oclusão e o tipo de escola. Feira de Santana - BA, zona urbana, 2002.

\begin{tabular}{crrrrrrr}
\hline $\begin{array}{c}\text { Condição } \\
\text { Oclusão }\end{array}$ & \multicolumn{3}{c}{ Estadual } & \multicolumn{3}{c}{ Municipal } & \multicolumn{2}{c}{ Particular } \\
\cline { 2 - 8 } & \multicolumn{3}{c}{ Ausente Presente } & Ausente & Presente Ausente Presente \\
\hline Sobres. Max. Ant. & № & 16 & 223 & 21 & 218 & 13 & 241 \\
& $\%$ & 6,7 & 93,3 & 8,8 & 91,2 & 5,1 & 94,9 \\
Sobres. Mand. Ant. & № & 233 & 6 & 235 & 4 & 252 & 2 \\
& $\%$ & 97,5 & 2,5 & 98,3 & 1,7 & 99,2 & 0,8 \\
Mordida Aberta Ant. & $N^{o}$ & 199 & 40 & 189 & 50 & 229 & 25 \\
& $\%$ & 83,3 & 16,7 & 79,1 & 20,9 & 90,2 & 9,8 \\
\hline
\end{tabular}

Em relação a sobressaliência maxilar e mandibular anterior, as distribuições foram semelhantes entre os tipos de escola, sem apresentar diferenças estatisticas em nivel de $5 \%\left(X^{2}=21,85 ; p=0,349\right.$ e $X^{2}=756 ; p=$ 0,272 , respectivamente). Na mordida aberta, apesar da distribuição ser desigual entre os tipos de escola, não foram verificadas diferenças estatisticamente significativas em nivel de $5 \%\left(X^{2}=15,50 ; p=0,344\right)$ (Tabela 26).

Tabela 27 - Distribuição do número e percentual de escolares de doze anos de idade segundo relação molar antero-posterior e tipo de escola. Feira de Santana - BA, zona urbana, 2002.

\begin{tabular}{ccccccc}
\hline \multirow{2}{*}{$\begin{array}{c}\text { Relação } \\
\text { Molar }\end{array}$} & \multicolumn{2}{c}{ Estadual } & \multicolumn{2}{c}{ Municipal } & \multicolumn{2}{c}{ Particular } \\
\cline { 2 - 7 } & No & $\%$ & № & $\%$ & № & $\%$ \\
\hline Normal & 57 & 23,8 & 81 & 33,9 & 86 & 33,9 \\
Meia cúspide & 44 & 18,4 & 50 & 20,9 & 101 & 39,8 \\
Cúspide inteira & 138 & 57,7 & 108 & 45,2 & 67 & 26,4 \\
\hline Total & $\mathbf{2 3 9}$ & $\mathbf{1 0 0}$ & $\mathbf{2 3 9}$ & $\mathbf{1 0 0}$ & $\mathbf{2 5 4}$ & $\mathbf{1 0 0}$ \\
\hline
\end{tabular}

Quanto à relação molar, apenas $23,8 \%$ das crianças nas escolas estaduais e $33,9 \%$ nas escolas municipais e particulares apresentaram relação normal. Sendo expressivo os percentuais de desvio da relação em cúspide inteira nas escolas estaduais e municipais. Estas diferenças foram 
estatisticamente significativas em nivel de $5 \%\left(X^{2}=59,53 ; p=0,000\right)$ (Tabela 27).

Tabela 28 - Distribuição do número e percentual de escolares de doze anos de idade segundo o grau de oclusopatia (DAl), sexo e o tipo de escola. Feira de Santana - BA, zona urbana, 2002.

\begin{tabular}{|c|c|c|c|c|c|c|c|}
\hline \multirow{2}{*}{$\begin{array}{c}\text { Grau de } \\
\text { Oclusopati }\end{array}$} & & \multicolumn{2}{|c|}{ Estadual } & \multicolumn{2}{|c|}{ Municipal } & \multicolumn{2}{|c|}{ Particular } \\
\hline & & $\mathrm{F}^{*}$ & $\overline{M^{*}}$ & $\bar{F}$ & $\mathbf{M}$ & $\bar{F}$ & $\bar{M}$ \\
\hline \multirow[t]{2}{*}{ Normal } & № & 57 & 50 & 66 & 59 & 77 & 55 \\
\hline & $\%$ & 41,3 & 49,5 & 52,4 & 52,2 & 54,2 & 49,1 \\
\hline \multirow[t]{2}{*}{ Definida } & № & 37 & 24 & 29 & 29 & 38 & 33 \\
\hline & $\%$ & 26,8 & 23,8 & 23,0 & 23,0 & 26,8 & 29,5 \\
\hline \multirow[t]{2}{*}{ Severa } & № & 19 & 15 & 11 & 7 & 13 & 13 \\
\hline & $\%$ & 13,8 & 14,9 & 8,7 & 6,2 & 9,2 & 11,6 \\
\hline \multirow[t]{2}{*}{ Incapacitante } & № & 25 & 12 & 20 & 18 & 14 & 11 \\
\hline & $\%$ & 18,1 & 11,9 & 15,9 & 15,9 & 9,9 & 9,8 \\
\hline \multirow[t]{2}{*}{ Total } & № & 138 & 101 & 126 & 113 & 142 & 112 \\
\hline & $\%$ & 100 & 100 & 100 & 100 & 100 & 100 \\
\hline
\end{tabular}

*:F = Sexo feminino e $M=$ Sexo masculino.

As prevalências dos graus de oclusopatia entre os sexos por tipo de escola ocorreram de forma equilibrada e não mostraram diferenças significativas em nivel de $5 \%$ ( Estaduais: $X^{2}=2,60 / p=0,457$; Municipais: $X^{2}=0,68 / p=0,878$ e Particulares: $X^{2}=0,84 / p=0,838$ ) (Tabela 28).

Sobre a etnia, foram observados maiores percentuais de grau de oclusão "normal" entre os "negros" de todos os tipos de escola; bem como maiores percentuais de "brancos" no grau "incapacitante". Nos demais graus as prevalências se distribuem desigualmente, no entanto não foram observadas diferenças significativas em nível de $5 \%$ na análise geral $\left(X^{2}=\right.$ $11,64 / p=0,070$ ) bem como na análise por tipo de escola (Estaduais: $X^{2}=$ $3,42 / p=0,754$; e Particulares: $X^{2}=11,73 / p=0,068$ ) exceto para as escolas municipais $\left(X^{2}=13,40 / p=0,037\right.$ ) (Tabela 29). 
Tabela 29 - Distribuição do número e percentual de escolares de doze anos de idade segundo o grau de oclusopatia (DAl), etnia e o tipo de escola. Feira de Santana - BA, zona urbana, 2002.

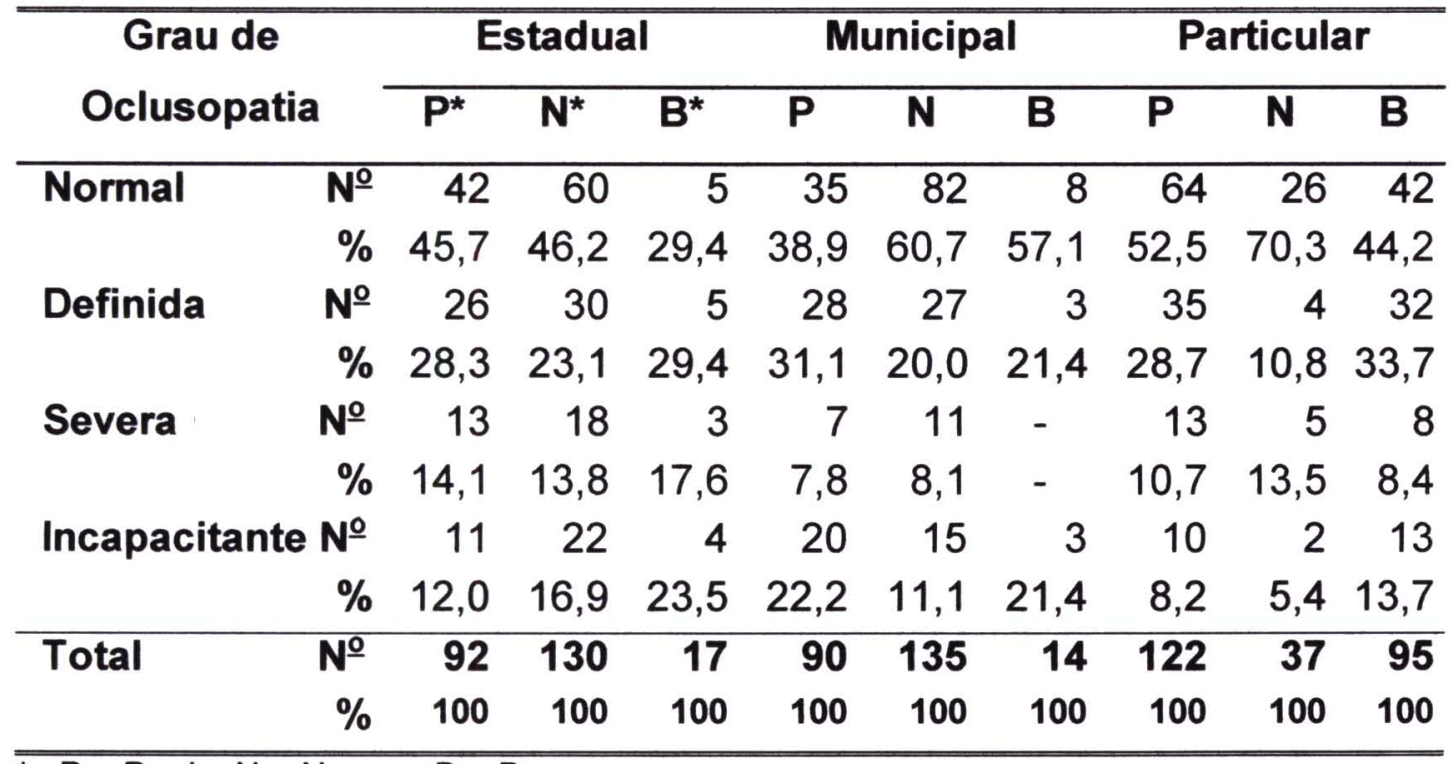

${ }^{*}: \mathrm{P}=$ Parda, $\mathrm{N}=$ Negra e $\mathrm{B}=$ Branca

Apesar de não ser objeto deste estudo, foi verificado nas crianças examinadas, que as distribuições das condições oclusais segundo o $C P O D \leq 3$ e $C P O D \geq 4$ foram semelhantes, não apresentando significância estatística no nivel de $5 \%$ (Coef. de Correlação de Spearman $r=0,054 ; p=$ $0,147)$. Estes dados estão apresentados na figura 5 .

Figura 5 - Distribuição percentual dos graus de oclusopatia em escolares de doze anos de idade segundo os valores $C P O D \leq 3$ e $C P O D \geq 4$. Feira de Santana - BA, zona urbana, 2002.

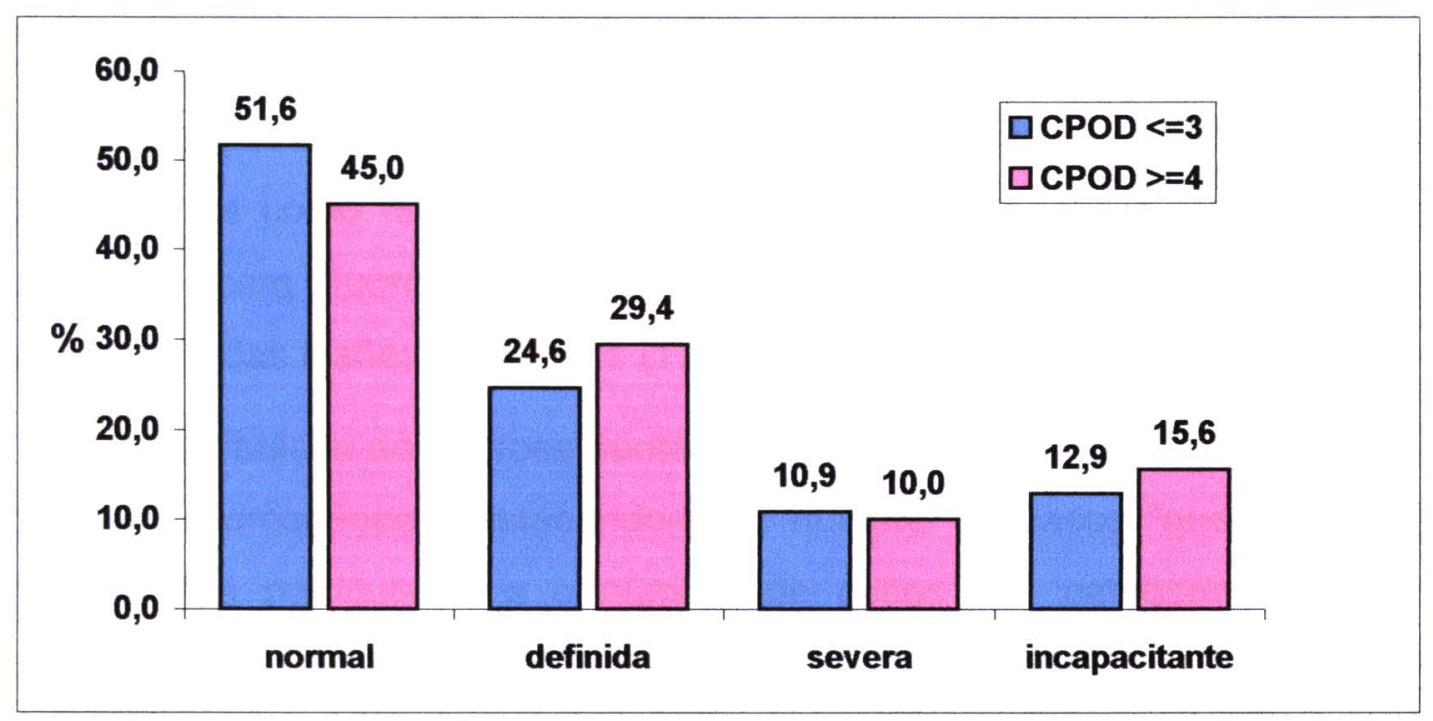


A correlação do DAl com o CPI também não foi estatisticamente significante em nivel de $5 \%$ (Coef. de Correlação de Spearman $r=0,0153 ; p$ $=0,678$ ).

\subsection{FLUOROSE DENTÁRIA}

Os graus de fluorose dentária nos escolares examinados estão apresentados na tabela 30 .

Tabela 30 - Distribuição do número e percentual de escolares de doze anos de idade segundo o grau de fluorose dentária e tipo de escola. Feira de Santana - BA, zona urbana, 2002.

\begin{tabular}{ccccccc}
\hline Fluorose & \multicolumn{2}{c}{ Estadual } & \multicolumn{2}{c}{ Municipal } & \multicolumn{2}{c}{ Particular } \\
\cline { 2 - 7 } Sem Fluorose & $\mathbf{N}^{\mathbf{0}}$ & $\%$ & $\mathbf{N}^{\circ}$ & $\%$ & $\mathbf{N}^{\circ}$ & $\%$ \\
\hline Normal (0) & 163 & 51,3 & 189 & 56,6 & 165 & 51,7 \\
Questionável (1) & 10 & 3,1 & 23 & 6,9 & 48 & 15,0 \\
Com Fluorose & & & & & & \\
Muito leve (2) & 74 & 23,3 & 73 & 21,9 & 64 & 20,1 \\
Leve (3) & 37 & 11,6 & 24 & 7,2 & 27 & 8,5 \\
Moderada (4) & 27 & 8,5 & 14 & 4,2 & 13 & 4,1 \\
Severa (5) & 7 & 2,2 & 11 & 3,3 & 2 & 0,6 \\
\hline Total & $\mathbf{3 1 8}$ & $\mathbf{1 0 0}$ & $\mathbf{3 3 4}$ & $\mathbf{1 0 0}$ & $\mathbf{3 1 9}$ & $\mathbf{1 0 0}$ \\
\hline
\end{tabular}

$\mathrm{Na}$ amostra examinada, a maioria dos indivíduos em todos os tipos de escola (Estaduais: 54,4\%; Municipais: 63,5\% e Particulares: $66,7 \%$ ) foram classificados como não portadores de fluorose dentária e a freqüência de escolares com fluorose diminuiu à medida que aumentou o grau de severidade das lesões fluoróticas (Tabela 30).

A distribuição da fluorose dentária entre os tipos de escola não ocorreu de forma homogênea, destacando-se o número de casos "questionáveis" nas escolas particulares e o número de casos nas categorias "leve" e "moderada" nas escolas estaduais. As diferenças foram estatisticamente significativas em nível de $5 \%\left(X^{2}=46,89 ; p=0,000\right)$ (Tabela 30 e Figura 6$)$. 
Figura 6 - Distribuição percentual dos graus de fluorose dentária em escolares de doze anos de idade segundo tipo de escola. Feira de Santana - BA, zona urbana, 2002.

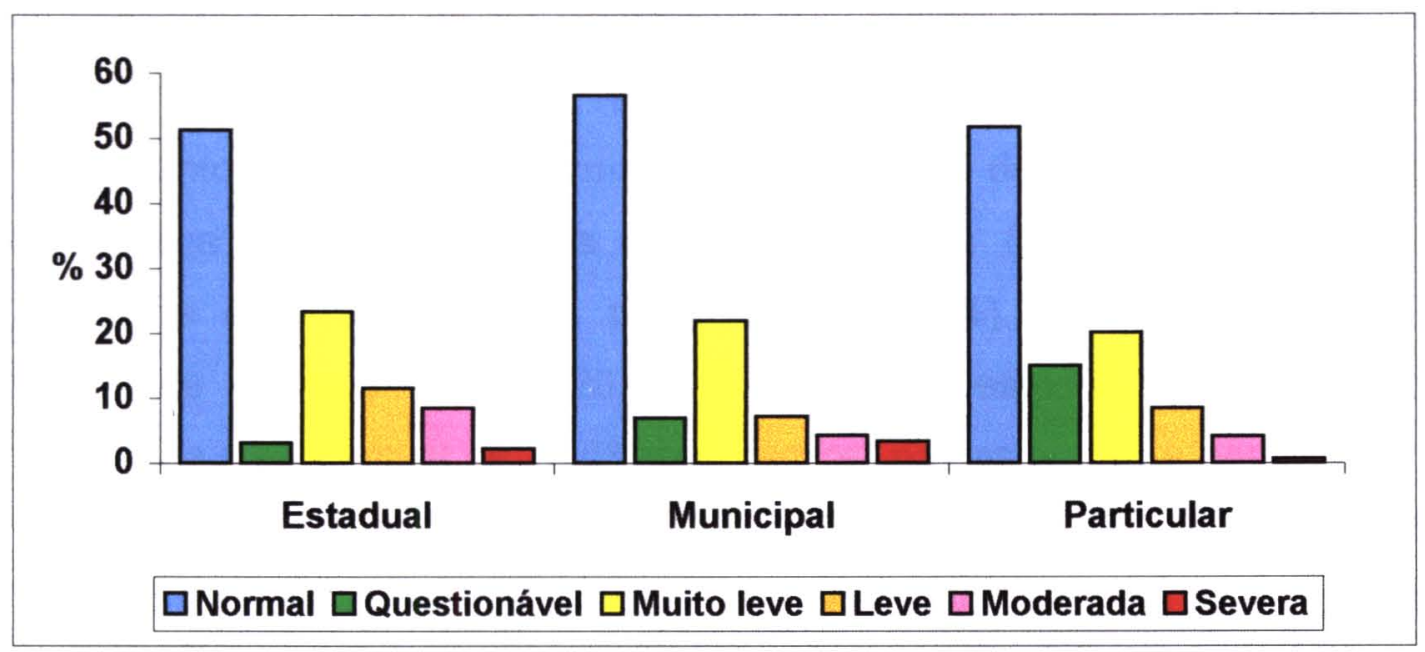

Tabela 31 - Distribuição do número e percentual de escolares de doze anos de idade segundo o grau de fluorose dentária, sexo e tipo de escola. Feira de Santana - BA, zona urbana, 2002.

\begin{tabular}{|c|c|c|c|c|c|c|c|}
\hline \multirow{2}{*}{\multicolumn{2}{|c|}{$\begin{array}{c}\text { Grau de Fluorose } \\
\text { Sem Fluorose }\end{array}$}} & \multicolumn{2}{|c|}{ Estadual } & \multicolumn{2}{|c|}{ Municipal } & \multicolumn{2}{|c|}{ Particular } \\
\hline & & $F^{*}$ & $\mathbf{M}^{*}$ & $\mathbf{F}$ & $\mathbf{M}$ & $F$ & $\mathbf{M}$ \\
\hline \multirow[t]{2}{*}{ Normal (0) } & $\mathrm{N}^{\mathrm{O}}$ & 84 & 79 & 95 & 94 & 93 & 72 \\
\hline & $\%$ & 49,1 & 53,7 & 58,3 & 55,0 & 52,0 & 51,4 \\
\hline \multirow[t]{2}{*}{ Questionável (1) } & № & 5 & 5 & 11 & 12 & 28 & 20 \\
\hline & $\%$ & 2,9 & 3,4 & 6,7 & 7,0 & 15,6 & 14,3 \\
\hline \multicolumn{8}{|l|}{ Com Fluorose } \\
\hline \multirow[t]{2}{*}{ Muito leve (2) } & № & 42 & 32 & 33 & 40 & 36 & 28 \\
\hline & $\%$ & 24,6 & 21,8 & 20,2 & 23,4 & 20,1 & 20,0 \\
\hline \multirow[t]{2}{*}{ Leve (3) } & № & 22 & 15 & 14 & 10 & 16 & 11 \\
\hline & $\%$ & 12,9 & 10,2 & 8,6 & 5,8 & 8,9 & 7,9 \\
\hline \multirow[t]{2}{*}{ Moderada (4) } & № & 16 & 11 & 5 & 9 & 6 & 7 \\
\hline & $\%$ & 9,4 & 7,5 & 3,1 & 5,3 & 3,4 & 5,0 \\
\hline \multirow[t]{2}{*}{ Severa (5) } & № & 2 & 5 & 5 & 6 & - & 2 \\
\hline & $\%$ & 1,2 & 3,4 & 3,1 & 3,5 & - & 1,4 \\
\hline \multirow[t]{2}{*}{ Total } & № & 171 & 147 & 163 & 171 & 179 & 140 \\
\hline & $\%$ & 100 & 100 & 100 & 100 & 100 & 100 \\
\hline
\end{tabular}

${ }^{\star}: \mathrm{F}=$ Sexo feminino e $\mathrm{M}=$ Sexo masculino. 
Entre os sexos, a distribuição segundo o tipo de escola foi relativamente equilibrada, não apresentando diferenças estatisticamente significativas em nivel de $5 \%$ (Estaduais: $X^{2}=3,24 / p=0,662$; Municipais: $X^{2}$ $=2,43 / p=0,787$ e Particulares: $X^{2}=3,29 / p=0,655$ ) (Tabela 31).

Quanto a etnia, destacam-se os percentuais de casos na categoria "muito leve" em "negros" nas escolas estaduais $(25,9 \%)$ e municipais $(22,2 \%)$ e em "brancos" nas particulares $(22,6 \%)$. Na categoria "leve" destaca-se o percentual de $20,0 \%$ nas escolas estaduais e nos casos moderados o percentual de $10,6 \%$ em "negros" nas estaduais e particulares. Ressalta-se na categoria "severa" a ausência de registro de casos no grupo "brancos". Estas diferenças apesar de terem apresentado significância estatística em nivel de $5 \%$ na análise geral $\left(X^{2}=19,38 ; p=0,036\right)$ não foram significativas quando se analisou segundo o tipo de escola (Estaduais: $X^{2}=$ $10,21 / p=0,421 ;$ Municipais: $X^{2}=9,12 / p=0,52$ e Particulares: $X^{2}=15,0 / p=$ 0,132 ) (Tabela 32).

Tabela 32 - Distribuição do número e percentual de escolares de doze anos de idade segundo o grau de fluorose dentária, etnia e tipo de escola. Feira de Santana - BA, zona urbana, 2002.

\begin{tabular}{|c|c|c|c|c|c|c|c|c|c|c|}
\hline \multirow{3}{*}{\multicolumn{2}{|c|}{$\begin{array}{c}\text { Grau de } \\
\text { Fluorose } \\
\text { Sem Fluorose }\end{array}$}} & \multirow{2}{*}{\multicolumn{3}{|c|}{ Estadual }} & \multirow{2}{*}{\multicolumn{3}{|c|}{ Municipal }} & \multirow{2}{*}{\multicolumn{3}{|c|}{ Particular }} \\
\hline & & & & & & & & & & \\
\hline & & \multirow{2}{*}{$\begin{array}{r}\mathbf{P}^{*} \\
72\end{array}$} & \multirow{2}{*}{$\frac{\mathbf{N}^{*}}{80}$} & \multirow{2}{*}{$\mathbf{B}^{*}$} & \multirow{2}{*}{$\begin{array}{l}P \\
83\end{array}$} & \multirow{2}{*}{$\begin{array}{l}\mathbf{N} \\
94\end{array}$} & \multirow{2}{*}{$\begin{array}{r}12 \\
60.0\end{array}$} & \multirow{2}{*}{\begin{tabular}{r}
\multicolumn{1}{c}{$P$} \\
75 \\
50.7
\end{tabular}} & \multirow{2}{*}{\begin{tabular}{r}
\multicolumn{1}{c}{$N$} \\
23 \\
48,9
\end{tabular}} & \multirow{2}{*}{$\begin{array}{r}\text { B } \\
67 \\
54.0\end{array}$} \\
\hline Normal (0) & $\begin{array}{l}\text { № } \\
\%\end{array}$ & & & & & & & & & \\
\hline Question & $\begin{array}{l}\% \\
\text { № }\end{array}$ & $\begin{array}{l}3 \\
6\end{array}$ & & & $\begin{array}{r}1,9 \\
5\end{array}$ & $\begin{array}{l}2,2 \\
15\end{array}$ & $\begin{array}{r}60,0 \\
3\end{array}$ & $\begin{array}{r}50,7 \\
26\end{array}$ & $\begin{array}{r}48,9 \\
7\end{array}$ & $\begin{array}{r}54,0 \\
15\end{array}$ \\
\hline & $\%$ & 4,7 & 1,8 & 5,0 & 3,7 & 8,3 & 15,0 & 17,6 & 14,9 & 12,1 \\
\hline \multicolumn{11}{|c|}{ Com Fluorose } \\
\hline Muito le & $\begin{array}{l}\text { № } \\
\%\end{array}$ & $\begin{array}{r}28 \\
21,9\end{array}$ & $\begin{array}{r}44 \\
25,9\end{array}$ & $\begin{array}{r}2 \\
10,0\end{array}$ & $\begin{array}{r}29 \\
21,6\end{array}$ & $\begin{array}{r}40 \\
22,2\end{array}$ & $\begin{array}{r}4 \\
20,0\end{array}$ & $\begin{array}{r}30 \\
20,3\end{array}$ & $\begin{array}{r}6 \\
12,8\end{array}$ & $\begin{array}{r}28 \\
22,6\end{array}$ \\
\hline \multirow[t]{2}{*}{ Leve (3) } & № & 12 & 21 & 4 & 7 & 16 & 1 & 13 & 6 & \\
\hline & $\%$ & 9,4 & 12,4 & 20,0 & 5,2 & 8,9 & 5,0 & 8,8 & 12,8 & 6,5 \\
\hline \multirow[t]{2}{*}{ Moderada (4) } & № & 7 & 18 & 2 & 6 & 8 & 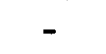 & 2 & 5 & \\
\hline & $\%$ & 5,5 & 10,6 & 10,0 & 4,5 & 4,4 & - & 1,4 & 10,6 & 4,8 \\
\hline \multirow[t]{2}{*}{ Severa (5) } & № & 3 & 4 & - & 4 & & _- & 2 & - & $e_{1}$ \\
\hline & $\%$ & 2,3 & 2,4 & - & 3,0 & 3,9 & - & 1,4 & - & - \\
\hline Total & $\begin{array}{r}\text { № } \\
\%\end{array}$ & $\begin{array}{l}128 \\
100\end{array}$ & $\begin{array}{l}170 \\
100\end{array}$ & $\begin{array}{r}20 \\
100\end{array}$ & $\begin{array}{l}134 \\
100\end{array}$ & $\begin{array}{l}180 \\
100\end{array}$ & $\begin{array}{r}20 \\
100\end{array}$ & $\begin{array}{l}148 \\
100\end{array}$ & $\begin{array}{r}47 \\
100\end{array}$ & $\begin{array}{l}\mathbf{1 2 4} \\
100\end{array}$ \\
\hline
\end{tabular}

${ }^{*}: \mathrm{P}=\mathrm{Parda}, \mathrm{N}=$ Negra e $\mathrm{B}=$ Branca. 
As correlações entre o Índice de Fluorose versus CPOD, CPI e DAI foram testadas e não demonstraram significância estatística (Coef. de Correlação de Spearman $r=0,050 / p=0,121 ; r=0,034 / p=0,286$ e $r=$ $0,0005 / p=0,990$, respectivamente)

\subsection{AÇÕES EM SAÚDE BUCAL AOS ESCOLARES}

O que pôde ser verificado paralelamente à pesquisa sobre as ações em saúde bucal voltadas para os escolares no municipio de Feira de Santana foi um cenário com atividades de promoção de saúde desenvolvidas por dois grupos diferentes:

1. Secretaria Municipal de Saúde: através do Programa de Saúde Bucal "Sorria Feira", implantado a partir do ano 2000 nas escolas municipais. Neste programa as atividades realizadas são de enfoque preventivo: escovação supervisionada, aplicação tópica de flúor e palestras educativas com pais, professores, funcionários e alunos. As ações executadas não são extensivas a toda a população de escolares destas escolas, visto que o programa é direcionado apenas as primeiras e segundas séries do ensino fundamental (PMFS/SMS 2002b).

2. Universidade Estadual de Feira de Santana: através de atividades orientadas pela Área de Odontologia Social, nas aulas práticas e de estágio de suas disciplinas, em algumas escolas da cidade (UEFS 2001).

Da forma como as atividades são desenvolvidas no município, a universalidade, um dos princípios norteadores do SUS e do atual paradigma de promoção de saúde, não é assegurado à população de escolares.

Quanto às ações curativas voltadas a este grupo populacional, predomina a livre demanda em serviços públicos e privados.

Sobre a orientação das ações, não foi constatada uma integração de metas entre as atividades realizadas pelos dois grupos anteriormente 
descritos, bem como parece inexistir o acompanhamento, monitoramento e avaliação das ações implementadas.

Uma medida de ação coletiva na prevenção de cárie existente no município é fluoretação da água de abastecimento público, que foi reimplantada, após 10 anos de paralisação, em 1997, mas que também não é monitorizada, através do princípio do heterocontrole, para a verificação dos teores de flúor na água ou para a avaliação do alcance da medida (SILVA CAL, ALVES e FREITAS 1998).

Outras ações possivelmente existentes que não são do conhecimento do autor desta pesquisa, a exemplo das citadas, espera-se que tenham futuramente uma coordenação para que se possa elaborar uma política de saúde bucal em Feira de Santana.

\subsection{FORMULÁRIOS DOS PAIS}

Ao todo 793 formulários foram respondidos pelos pais, distribuidos da seguinte forma: 284 nas escolas estaduais, 247 nas municipais e 262 nas particulares; o que representou um percentual de perdas de 10,7, 26,0 e 17,9 , respectivamente, em relação ao número de crianças examinadas em cada tipo de escola. Tais perdas ocorreram principalmente porque alguns pais permitiram que seus filhos fossem examinados, mas não concordaram em preencher os formulários, em função dos dados pessoais solicitados, mesmo a pesquisadora tendo assegurado o sigilo ético das informaçōes. Assim, as respostas coletadas serão apresentadas a seguir, mas não se referem ao total de crianças examinadas e serão utilizadas como possiveis explicações sociais, culturais e econômicas para os índices de saúde bucal que foram descritos nos itens anteriores deste capitulo.

$\mathrm{Na}$ distribuição dos pais em relação ao tipo de ocupação destacam-se os percentuais de pais nas escolas particulares como comerciantes $(15,3 \%)$ e funcionários públicos $(25,6 \%)$ (Tabela 33$)$. Outros pontos importantes são que os percentuais de profissionais autônomos das escolas públicas, 
estaduais $(35,9 \%)$ e municipais $(31,2 \%)$ além de mais elevados, diferem em sua composição do percentual nas escolas particulares $(24,0 \%)$ já que representam especialmente pessoas com atividades no mercado informal, enquanto que nas particulares são profissionais liberais atuando no mercado formal. Na categoria "outros", os percentuais descritos diferem não só nos valores, mas também na composição, havendo um predomínio de desempregados e donas de casa (do lar) nas escolas públicas e de aposentados nas particulares.

Tabela 33 - Distribuição do número e percentual de pais de escolares de doze anos de idade segundo o tipo de ocupação e de escola. Feira de Santana - BA, zona urbana, 2002.

\begin{tabular}{ccccccc}
\hline \multirow{2}{*}{ Ocupação } & \multicolumn{2}{c}{ Estadual } & \multicolumn{2}{c}{ Municipal } & \multicolumn{2}{c}{ Particular } \\
\cline { 2 - 7 } & No & $\%$ & No & $\%$ & No & $\%$ \\
\hline Agricultor & 7 & 2,5 & 13 & 5,3 & 4 & 1,5 \\
Industriário & 19 & 6,7 & 14 & 5,7 & 23 & 8,8 \\
Comerciário & 32 & 11,3 & 19 & 7,7 & 29 & 11,1 \\
Comerciante & 22 & 7,7 & 14 & 5,7 & 40 & 15,3 \\
Func. Público & 22 & 7,7 & 11 & 4,5 & 67 & 25,6 \\
Industrial & 2 & 0,7 & 2 & 0,8 & 1 & 0,4 \\
Autônomo & 102 & 35,9 & 77 & 31,2 & 63 & 24,0 \\
Outros & 78 & 27,5 & 97 & 39,3 & 35 & 13,4 \\
\hline Total & $\mathbf{2 8 4}$ & $\mathbf{1 0 0}$ & $\mathbf{2 4 7}$ & $\mathbf{1 0 0}$ & $\mathbf{2 6 2}$ & $\mathbf{1 0 0}$ \\
\hline
\end{tabular}

Quanto à escolaridade, pode ser observado o predomínio de pais com o primeiro grau incompleto nas escolas públicas, sendo que houve uma tendência decrescente dos percentuais à medida que aumentava o nivel de escolaridade. Ao contrário, nas escolas particulares predominou pais com o segundo grau completo, bem como nos niveis de escolaridade mais altos, como terceiro grau completo e pós-graduação, são perceptíveis as diferenças em relação às escolas públicas (Tabela 34). 
Tabela 34 - Distribuição do número e percentual de pais de escolares de doze anos de idade segundo o nível de escolaridade e tipo de escola. Feira de Santana - BA, zona urbana, 2002.

\begin{tabular}{ccccccc}
\hline \multirow{2}{*}{ Escolaridade } & \multicolumn{2}{c}{ Estadual } & \multicolumn{2}{c}{ Municipal } & \multicolumn{2}{c}{ Particular } \\
\cline { 2 - 7 } & $\mathbf{N}^{\circ}$ & $\%$ & $\mathbf{N}^{\circ}$ & $\%$ & $\mathbf{N}^{\circ}$ & $\%$ \\
\hline $\mathbf{1}^{\circ}$ grau incompleto & 128 & 45,1 & 144 & 58,3 & $\mathbf{2 5}$ & 9,5 \\
$\mathbf{1}^{\circ}$ grau completo & 64 & 22,5 & 62 & $\mathbf{2 5 , 1}$ & 22 & 8,4 \\
$\mathbf{2}^{\mathbf{0}}$ grau incompleto & 30 & 10,6 & 15 & 6,1 & 27 & 10,3 \\
$\mathbf{2}^{\circ}$ grau completo & 38 & 13,4 & 12 & 4,9 & 119 & 45,4 \\
$\mathbf{3}^{\circ}$ grau incompleto & 6 & 2,1 & 6 & 2,4 & 18 & 6,9 \\
$\mathbf{3}^{\circ}$ grau completo & $\mathbf{8}$ & $\mathbf{2 , 8}$ & 4 & 1,6 & 31 & 11,8 \\
Pós-graduação & 10 & $\mathbf{3 , 5}$ & 4 & 1,6 & 20 & 7,6 \\
\hline Total & $\mathbf{2 8 4}$ & $\mathbf{1 0 0}$ & $\mathbf{2 4 7}$ & $\mathbf{1 0 0}$ & $\mathbf{2 6 2}$ & $\mathbf{1 0 0}$ \\
\hline
\end{tabular}

Com respeito à renda familiar, o comportamento da distribuição é similar à observada no nivel de escolaridade. Nas escolas públicas houve uma tendência decrescente dos percentuais à medida que aumentava a faixa de renda salarial, enquanto que nas escolas particulares ocorre 0 inverso (Tabela 35).

Tabela 35 - Distribuição do número e percentual de pais de escolares de doze anos de idade segundo a renda familiar em salários mínimos (S.M.) e tipo de escola. Feira de Santana - BA, zona urbana, 2002.

\begin{tabular}{|c|c|c|c|c|c|c|}
\hline \multirow{2}{*}{ Renda Familiar } & \multicolumn{2}{|c|}{ Estadual } & \multicolumn{2}{|c|}{ Municipal } & \multicolumn{2}{|c|}{ Particular } \\
\hline & № & $\%$ & № & $\%$ & $\mathbf{N}^{\circ}$ & $\%$ \\
\hline$\leq 1$ S.M. & 181 & 63,7 & 194 & 78,5 & 12 & 4,6 \\
\hline $1-2$ S.M. & 59 & 20,8 & 40 & 16,2 & 39 & 14,9 \\
\hline $2-3$ S.M. & 16 & 5,6 & 6 & 2,4 & 44 & 16,8 \\
\hline $3-$ S.M. & 15 & 5,3 & 7 & 2,8 & 73 & 27,9 \\
\hline > 5 S.M. & 13 & 4,6 & - & - & 94 & 35,9 \\
\hline Total & 284 & 100 & 247 & 100 & 262 & 100 \\
\hline
\end{tabular}

Em relação ao tempo de residência a maioria dos pais $(77,0 \%)$ informou residir no município por um período de 11 anos ou mais, $14,5 \% \mathrm{em}$ torno de 6 a 10 anos e $8,4 \%$ de 0 a 5 anos. Esta distribuição teve comportamento similar em todos os tipos de escolas. 
Quanto à fonte da água de consumo na residência relatada pelos pais das escolas públicas, há um predomínio da rede de abastecimento público, através da EMBASA, representado por $77,5 \%$ nas escolas estaduais e $73,7 \%$ nas municipais. Nas escolas particulares o percentual cai para $56,5 \%$.

Sobre a saúde bucal de seus filhos, nas escolas particulares os pais atribuíram melhores condições bucais, ao passo que ocorreu o inverso nas escolas públicas, onde na condição "ruim" o percentual registrado nas escolas municipais $(27,5 \%)$ foi muito maior que nas particulares $(2,7 \%)$ (Tabela 36).

Tabela 36 - Distribuição do número e percentual de pais de escolares de doze anos de idade segundo a qualificação da saúde bucal de seus filhos e tipo de escola. Feira de Santana - BA, zona urbana, 2002.

\begin{tabular}{ccccccc}
\hline \multirow{2}{*}{ Saúde Bucal } & \multicolumn{2}{c}{ Estadual } & \multicolumn{2}{c}{ Municipal } & \multicolumn{2}{c}{ Particular } \\
\cline { 2 - 7 } & № & $\mathbf{\%}$ & № & $\%$ & № & $\%$ \\
\hline Excelente & 8 & 2,8 & 2 & 0,8 & 23 & 8,8 \\
Muito Boa & 12 & 4,2 & 6 & 2,4 & 33 & 12,6 \\
Boa & 45 & 15,8 & 30 & 12,1 & 95 & 36,3 \\
Razoável & 162 & 57,0 & 141 & 57,1 & 104 & 39,7 \\
Ruim & 57 & 20,1 & 68 & 27,5 & 7 & 2,7 \\
\hline Total & $\mathbf{2 8 4}$ & $\mathbf{1 0 0}$ & $\mathbf{2 4 7}$ & $\mathbf{1 0 0}$ & $\mathbf{2 6 2}$ & $\mathbf{1 0 0}$ \\
\hline
\end{tabular}

Com respeito à pergunta sobre se a saúde bucal da criança interferia na frequência escolar, nas escolas particulares $95,0 \%$ das respostas foi negativa, diminuindo para $72,9 \%$ nas escolas estaduais e $63,6 \%$ nas municipais. Quando a resposta foi positiva houve predomínio de falta escolar 1 vez por mês.

As respostas sobre a filiação a planos de atendimento odontológico demonstraram também distribuições diferentes entre as escolas públicas e particulares. Nas públicas as respostas foram negativas em $95,1 \%$ das escolas estaduais e $95,5 \%$ nas municipais, ao passo que nas particulares o percentual de respostas afirmativas $(24,4 \%)$ foi 5 vezes maior. 
Sobre a realização de tratamento odontológico no ano anterior $70,8 \%$ das crianças nas escolas estaduais e $79,8 \%$ nas municipais não haviam recebido tratamento, ao contrário nas particulares $65,6 \%$ haviam recebido tratamento. Dentre os escolares, sobre os quais foi afirmada a realização de tratamento no ano anterior, distribuições de comportamentos diferentes entre as escolas públicas e privadas continuam a ocorrer em relação ao local do atendimento. Nas escolas estaduais $(62,0 \%)$ e nas municipais $(84,0 \%)$ recebeu atendimento público seja em posto de saúde, escola ou UEFS, enquanto que nas escolas particulares $92,4 \%$ recebeu atendimento em consultório particular.

As respostas dos pais, em relação ao acesso de informações sobre como cuidar da saúde bucal de seus filhos, foram afirmativas em $56,7 \%$ nas escolas estaduais, $48,6 \%$ nas municipais e $82,4 \%$ nas particulares. Isto demonstrou um maior acesso a informações dos pais das escolas particulares.

\subsection{FORMULÁRIOS DAS CRIANÇAS}

Ao todo 725 formulários foram respondidos pelas crianças: 251 nas escolas estaduais, 187 nas municipais e 287 nas particulares; o que representou um percentual de perdas de $21,1,44,0$ e 10,0 respectivamente em relação ao número de crianças examinadas em cada tipo de escola. Comparados aos números de formulários respondidos pelos pais, os percentuais de perda aumentaram nas escolas públicas e diminuíram nas particulares. Nas escolas municipais o alto percentual de perda foi devido principalmente à grande dificuldade dos escolares no preenchimento dos formulários, pois nestas escolas várias crianças se encontravam semialfabetizadas, em atraso na série escolar. Porém nas escolas estaduais e particulares os formulários não foram preenchidos quando a presença do escolar em atividade na sala de aulas era prioritária. Desta forma, as respostas relatadas a seguir, similarmente às respostas dos pais serão 
interpretadas como possiveis explicações para os índices de saúde bucal que foram descritos anteriormente.

As três primeiras perguntas do formulário das crianças se referiam ao uso de flúor tópico na escola. Em nenhuma das escolas particulares foi relatado o uso tópico de flúor. Nas escolas públicas somente 52 crianças confirmaram esta utilização, especialmente o flúor em gel, o que representou $7,17 \%$ do total de formulários respondidos. Dentre estas crianças, 13 eram de escolas estaduais, mas tinham usado o flúor nas escolas municipais onde estudaram nos anos anteriores, e as outras 29 eram de escolas municipais. Portanto, o uso tópico de flúor ocorreu somente nas escolas municipais onde o Programa Sorria Feira havia sido implantado.

Quanto ao consumo de peixe e chá preto, alimentos descritos como potencialmente de alto teor de flúor, verificou-se que: $84,4 \%$ das crianças relataram consumir peixe com freqüência $(90,0 \%)$ de uma vez por semana e $98,9 \%$ não bebiam chá preto sendo que nos casos em que o chá era consumido, a freqüência mais prevalente também foi uma vez por semana.

Com relação aos hábitos de higiene bucal, $95,6 \%$ dos escolares responderam que realizavam a limpeza bucal diariamente. Com respeito ao número de vezes em que a limpeza bucal era realizada por dia prevaleceu a freqüência "mais de duas vezes" $(55,3 \%)$, seguida de "duas vezes" $(37,7 \%)$ e "uma vez" (7,0\%).

Quanto aos meios e métodos de higiene bucal, foi verificado que nas escolas públicas prevaleceu a escovação como método mais utilizado, nas estaduais $(78,9 \%)$ e nas municipais $(82,9 \%)$, enquanto que nas particulares $61,0 \%$ dos escolares associavam à escovação outros métodos como fio dental, limpa língua e enxaguatórios bucais. Nenhum outro método alternativo de higiene bucal foi relatado.

Ainda sobre higiene bucal, $98,6 \%$ possuiam a sua própria escova dental, $96,3 \%$ utilizavam pasta dental sempre que escovavam os dentes. Sendo que sobre a concentração de flúor nas pastas, os dados foram agrupados da seguinte forma: pastas sem flúor, com até $1.187 \mathrm{ppmF}$ e com 
1.500 ppmF ou mais; e constatou-se que $99,2 \%$ das pastas utilizadas se enquadravam na categoria de maior concentração.

Sobre o consumo de doces, nas escolas públicas a resposta mais prevalente nas escolas públicas foi "às vezes" nas estaduais $(61,8 \%)$ e nas municipais $(60,4 \%)$ seguida da resposta "freqüentemente" nos seguintes percentuais $27,5 \%$ e $34,2 \%$, respectivamente. Mas nas escolas particulares - predomínio de respostas se inverte, 50,5\% consumiam doces "freqüentemente" e 44,6\% "às vezes".

Esses dados são confirmados quando relacionados à pergunta seguinte, sobre o consumo no dia anterior, visto que a frequência de consumo de "0-2 vezes" nas escolas públicas, estaduais $(68,5 \%)$ e municipais $(57,8 \%)$, foi maior que nas particulares $(54,0 \%)$; enquanto que a freqüência "3-5 vezes" foi maior nas particulares $(33,4 \%)$ que nas estaduais $(18,3 \%)$ e municipais $(29,9 \%)$. Portanto, houve um consumo mais freqüente de doces pelas crianças das escolas particulares. 


\section{DISCUSSÃO}

Neste capitulo serão discutidos os resultados dos índices investigados confronando-os com a literatura seguindo a mesma ordem em que estes índices foram apresentados no capítulo Resultados.

Os motivos para as perdas na amostra foram vários: crianças sem autorização para a participação na pesquisa, especialmente nas escolas particulares, faltas dos escolares no dia do exame, feriados do racionamento de energia e greve policial que provocaram suspensão das aulas com alteração do calendário escolar, recusa do escolar em se submeter ao exame, evasão da escola e realização de atividades extras na escola impedindo a presença do escolar para o exame. Ressalta-se também, que foi adotado como critério para a pesquisa que o escolar ausente no dia do exame não seria substituído. Motivos e percentuais de perdas semelhantes foram descritos por outros pesquisadores (FERNANDEZ et al. 1999; PATIÑO 2001; RIORDAN 1991; RIORDAN e BANKS 1991; SILVA DRAD et al. 1995; STIZ 2001).

As perdas observadas situam-se em um percentual médio de $29,7 \%$ o que representa um valor acima do esperado de $20 \%$. A literatura não apresenta um consenso sobre qual seria o percentual de perdas aceitável. Um ponto importante que não deve ser desprezado é se estas perdas poderiam criar algum viés nos resultados, ou melhor, se as crianças examinadas seriam diferentes daquelas não examinadas. Neste trabalho, assume-se que isto não aconteceu, pois os escolares, em cada tipo de escola, tiveram chances semelhantes de serem sorteados para compor a amostra, assim como, os motivos para as perdas não se relacionaram ao projeto em si, tendo sido outros que fugiram ao controle da pesquisadora, o que concorda com os trabalhos de PATIÑO (2001) e STIZ (2001).

Várias fórmulas têm sido propostas para definir o tamanho amostral (OLIVEIRA et al. 1998; SILVA NN da 1998 ; LUIZ e MAGNANINI 2001). Na presente pesquisa, o número total de escolares examinados pode ser considerado representativo da população de referência em cada tipo de 
escola, visto que cada criança apresentou uma probabilidade conhecida e diferente de zero de pertencer à amostra. Além de que, segundo proposta da OMS (WHO 1987) de tamanho da amostra estaria em um valor mínimo de 25 a 50 elementos amostrais para cada tipo de escola.

A distribuição quanto ao sexo (Tabela 4) se mostrou semelhante à distribuição populacional para o município de Feira de Santana que apresenta ligeiro predominio do sexo feminino em sua pirâmide etária e à distribuição dos escolares com doze anos de idade segundo sexo, dependência administrativa e localização da escola (Tabela 3).

A distribuição amostral quanto a etnia e tipo de escola se mostrou desigual, o que levantou a possibilidade de que o tipo de escola poderia estar atuando como um fator modificador nesta distribuição. Então, realizouse a análise dos dados sem e com a distribuição por tipo de escola. Assim, nos indices CPOD e Fluorose, os resultados da análise geral, sem diferenças estatísticas, foram confirmados com a análise por tipo de escola. No $\mathrm{CPI}$, na análise geral foi observada diferença estatística, mas na análise entre os tipos de escola, apesar de distribuição desigual, a diferença não se manteve. No DAI, na análise geral não houve diferença, mas entre os tipos de escola foi registrada diferença estatística apenas nas escolas municipais, a qual pode ter sido conseqüente a alta prevalência da condição "normal" $(60,7 \%)$ em "negros", grupo este que representa a maioria $(56,5 \%)$ na distribuição étnica deste tipo de escola.

Desta forma, os dados em relação a etnia, devem ser interpretados com cautela, pois podem estar sendo delineados devido a fatores comportamentais, econômicos, culturais e sociais. Ressalta-se ainda que neste trabalho não foi realizada a estratificação segundo grupo étnico por tipo de escola. Trabalhos com amostra estratificada para esta variável poderão vir a responder melhor as questões surgidas.

A distribuição geográfica do total de escolas e entre os tipos (Figura 2) mostrou que em toda a área urbana, seja central ou periférica, houve a representação adequada das escolas, bem como a localização nos mesmos 
bairros entre os diferentes tipos de escola. Esta representação geográfica permite afirmar que os indices apresentados são realmente referentes a toda extensão da área urbana e não somente relativos a áreas periféricas mais pobres, onde possivelmente os indicadores de saúde podem estar sendo influenciados por piores condições sócio-econômicas da população (PATUSSI 2000).

A realização da calibração inicial e de exames em duplicata, durante a fase de coleta de dados, em cerca de $10 \%$ da amostra tem sido preconizada pela OMS (WHO 1987, 1997). Para a OMS, a concordância para a maioria das avaliações deve estar na faixa de $85-95 \%$. Mas, a avaliação do percentual de concordância geral exclusivamente não permite assegurar a confiabilidade dos dados levantados pelo examinador. A aplicação da planilha de dupla entrada e a utilização do coeficiente Kappa como instrumento de avaliação da confiabilidade é muito mais eficiente por diminuir a proporção de concordâncias atribuídas ao acaso (FRIAS 2000). A OMS em nova versão do seu manual para levantamentos epidemiológicos (WHO 1997) passou a adotar a aplicação do Kappa, o qual tem sido indicada a sua utilização por vários autores (BULMAN e OSBORN 1989; PEREIRA 1995; ALMEIDA FILHO e ROUQUAYROL 2002).

Neste trabalho os índices de Kappa calculados durante a fase de calibração apresentaram a necessidade de reforço do examinador quanto aos critérios do CPI, desalinhamento mandibular, sobressaliência maxilar, relação molar e necessidade de tratamento. Em relação ao $\mathrm{CPI}$, o maior número de discordâncias ocorreu entre "sadio" ou "sangramento", o que pode estar relacionado à reversibilidade da reação inflamatória local pela ausência ou presença de placa bacteriana nos diferentes dias de exame. $\mathrm{Na}$ sobressaliência maxilar é possivel que nos dois momentos de medida tenha ocorrido desvio das arcadas durante a oclusão pela criança, o que pode ter interferido no registro da medida $\mathrm{em} \mathrm{mm}$. A quantidade de crianças na calibração inicial foi menor em relação à segunda calibração, o que pode ter influenciado mais no cálculo do índice. Desta forma, na fase de coleta de dados, todos os indices registrados demonstraram excelente 
reprodutibilidade de critérios do examinador, o que permite a confiabilidade dos resultados da pesquisa

Sobre a frequência dos valores do CPOD (Tabela 7), o fenômeno descrito na literatura como polarização, onde o maior de número de dentes cariados perdidos e obturados se concentra em um menor grupo da população foi observado (NARVAl et al. 2002). Este mesmo fenômeno foi registrado por SILVA DRAD et al. (1995) em Santos - SP, FERNANDEZ et al. (1999) em Osasco - SP, PATIÑO (2001) em escolares de Camboriú - SC, por BASTOS et al. (2002) e por SALES-PERES e BASTOS (2002).

Aos doze anos, segundo as metas propostas pela OMS/ FDI, relativas à cárie dentária, para o ano 2000 (FDI 1982), O CPOD deve ser menor ou igual a três. Neste trabalho, os CPODs médios registrados para os escolares nos diferentes tipos de escola se encontram abaixo do valor máximo proposto pela OMS para esta idade indice, o que significa dizer que a meta foi atingida. Espera-se que a meta da OMS/FDI delineada para 2010, embora ainda não oficializada pela organização, (NARVAI 2002), CPOD $<1$, também possa ser alcançada com sucesso.

Quanto aos escolares livres de cárie aos doze anos, mais de $30,0 \%$ nos três tipos de escola, esta mesma faixa percentual foi observada nos trabalhos da USP/FSP (1997) em São Paulo - SP, PATUSSI (2000) em diferentes regiões sócio-econômicas do Distrito Federal, SANTOS et al. (2000) em Belo Horizonte e PATIÑO (2001) em Camboriú - SC.

Comparativamente, a composição do índice CPOD foi diferente entre as escolas públicas e privadas. Essa diferença está em concordância com Al KHATEEB et al. (1991), FREIRE, MELO e SILVA (1996), USP/FSP (1997), NARVAI, CASTELLANOS E FRAZĀO (2000), MALTZ e SILVA (2001), SILVA DRAD et al. (1995). Também demonstrou o acúmulo de dentes sem tratamento em escolas públicas e uma prevalência mais elevada de dentes restaurados (Obturados) nas particulares, o que possivelmente pode ser devido a um deficiente acesso aos serviços odontológicos das crianças nas primeiras escolas e a um melhor acesso nas segundas. Podem, também, 
estar relacionados ao maior CPOD médio registrado nas escolas particulares, mesmo que não estatisticamente significativo em relação às escolas públicas.

Vale destacar que o diagnóstico da cárie nos dentes obturados foi feito, anteriormente, pelo profissional que realizou o tratamento restaurador, podendo este diagnóstico variar de acordo com o critério clínico empregado, fugindo totalmente ao controle do examinador em levantamentos epidemiológicos (RIORDAN 1991; FREYSLEBEN, PERES e MARCENES 2000).

$\mathrm{Na}$ presente pesquisa, não foram identificadas diferenças entre os valores médios de CPOD entre os tipos de escola o que difere do verificado por alguns trabalhos na literatura (AI KHATEEB, AI-MARSAFI e O'MULLANE 1991; FREIRE, MELO e SILVA 1996; NARVAI, CASTELLANOS e FRAZÃO 2000; MALTZ e SILVA 2001).

A literatura sobre a prevalência de cárie quanto ao sexo, apresenta resultados divergentes, com uma maior prevalência no sexo feminino (LOPES e BASTOS 1998 citado por SALES-PERES e BASTOS 2002) ou no sexo masculino (SALES-PERES e BASTOS 2002). Neste trabalho, não foi registrada diferença estatística do CPOD em relação ao sexo, o que concorda com os resultados de TOMITA et al. (1996) e FREYSLEBEN, PERES e MARCENES (2000).

Alguns estudos de prevalência de cárie registraram diferenças entre grupos étnicos, com uma maior prevalência de cárie em crianças "brancas" (SOUZA et al. 1967; CASTELLANOS 1974), contrariamente no presente estudo não foram verificadas diferenças.

A distribuição das necessidades de tratamento caracterizou que mais de $90 \%$ dos dentes dos escolares não apresentaram necessidades (Tabela 8), o que concorda com os dados de FERNANDEZ et al. (1999) e SILVA DRAD et al. (1995).

Do ponto de vista coletivo, implica dizer que ações programáticas direcionadas a este grupo populacional devem considerar que apenas em 
uma parcela dos individuos (Estaduais: $30,5 \%$; Municipais: $31,4 \%$ e Particulares: $44,2 \%$ ) se concentram as necessidades, portanto, o enfoque de risco populacional, onde as ações são definidas segundo os grupos de indivíduos de maior risco deve ser adotado para diminuir custos, redirecionar programas e não promover o sobretratamento dos indivíduos menos afetados pela doença.

A prevalência mais elevada de tratamentos curativos e mais complexos nas escolas públicas (Tabela 13), tais como, exodontia e tratamento pulpar/restaurador, evidenciou o agravamento das necessidades que podem mais uma vez estar relacionadas ao deficiente acesso aos serviços odontológicos o que dificulta a adoção de medidas preventivas, o diagnóstico precoce e o tratamento imediato nestes escolares.

Em relação às doenças periodontais (Tabela 14), o percentual observado de escolares na condição "sadio", exceto para as escolas particulares, foi menor que os registrado por STIZ (2001) e maior que os verificados por SONGPAISAN e DAVIES (1989) e DINI (2001).

A condição "sangramento", que caracteriza uma fase reversível da doença, se mostrou homogênea entre os tipos de escola diferindo dos resultados relatados por MALTZ e SILVA (2001) onde crianças de escolas públicas apresentaram maiores Indices de Sangramento Gengival do que as das escolas particulares. A identificação desta condição é um sinal de que é importante intervir neste momento, pois se não tratada pode evoluir para uma condição de lesão avançada.

O relacionamento entre a prevalência de cárie de regiōes com baixo ou moderado teor de flúor na água de abastecimento e pobre higiene oral, mensurada através Índice de Higiene Oral, tem sido atualmente descrito na literatura (SAMPAIO et al 2000). Neste trabalho não foi constatada associação entre o CPOD e ० $\mathrm{CPI}$, nem tampouco do CPOD com a condição "sangramento", a qual pode ser devido a um maior acúmulo de placa, ou seja, a uma deficiente higiene oral. 
O percentual da condição "cálculo" nas escolas públicas difere dos resultados encontrados por FRATUCCI (2000), mas são semelhantes aos registrados pela USP/FSP (1997) para adolescentes. Este percentual é preocupante porque o cálculo é um depósito de bactérias que favorece a uma maior agressão ao hospedeiro bem como à recessão gengical.

A saúde periodontal mais favorável no sexo feminino nas escolas municipais pode ser justificada pelo maior interesse das meninas com a higiene bucal e cuidados estéticos. Esse resultado está de acordo com (SHANLEY e AHERN 1984; RAMFJORD e ASH 1991) e contrário aos resultados encontrados por DINI (2001) e STIZ (2001). Para as demais escolas, onde não houve diferença, os resultados estão em consonância com o trabalho de DINI (2001).

Não foram constatadas diferenças no $\mathrm{CPI}$ em relação à etnia, o que difere da literatura onde piores condições de saúde periodontal para o grupo étnico "negro" foram relatadas por RAMFJORD e ASH (1991) e BORRELL et al. (2002).

Quanto às condições periodontais, segundo a localização dos sextantes (Tabela 18), confirmam os resultados verificados em São Paulo, em 1986 e 1998, para as condições "sadio" e "cálculo", entretanto, diferem em relação a condição "sangramento" (MARQUES 2000). Por outro lado, para a última condição o resultado coincide com o de SHANLEY e AHERN (1984). Estes resultados se justificam pela localização anatômica dos sextantes a que estão relacionados: o sextante central superior, que apresentou maior percentual na condição "sadio" é uma área de maior facilidade de higienização e os sextantes direito/esquerdo superiores e central inferior apresentaram altos percentuais de cálculo, sendo áreas de saida dos ductos das glândulas parótidas e sublingual respectivamente, além de serem de mais difícil higienização.

Em relação à média de sextantes sadios nas escolas públicas (Tabela 19), os resultados são idênticos aos observados nos estudos em São Paulo (MARQUES 2000), mas são superiores nas escolas particulares. Para as 
crianças examinadas, o número médio de sextantes sadios se encontra superior a outros trabalhos na literatura (SONGPAISAN e DAVIES 1989). De acordo com as metas propostas pela FDI (1984) para doença periodontal, encontram-se acima da média proposta para adolescentes de um mínimo de dois ou três sextantes sadios.

A prevalência das oclusopatias nos escolares, independente do tipo de escola, foi alta (Tabela 23), concordando com GALVÃO, PEREIRA e BELO (1994). A distribuição dos graus de oclusopatia demonstrou que as proporções no grau "definido", "severo" e "incapacitante" foram menores às observadas, em escolares de doze anos, por FRAZÃO et al. (2002), enquanto que a proporção da condição "normal" foi maior, apesar das diferenças metodológicas. Entretanto, o registro de escolares no grau "incapacitante" (Estaduais: 15,5\%; Municipais: 15,9\% e Particulares: 9,8\%) não é usual. Esse registro pode ser justificado pelo percentual elevado de mordida aberta vertical anterior verificado nesse trabalho (Tabela 26) e também pelo alto percentual de relação molar "cúspide inteira", especialmente nas escolas estaduais e municipais (Tabela 27), sendo provável que estas duas condiçōes tenham exercido influência na equação de cálculo do DAl e consequentemente no seu valor final. A distribuição das oclusopatias verificada em Osasco - SP (FERNANDEZ et al. 1999) concorda à registrada no presente trabalho.

Esta distribuição também revela uma questão importante no que se refere à indicação de tratamento da oclusopatia (Quadro1). Os dados demonstram que em $20 \%$ ou mais dos escolares, independente do tipo de escola, o tratamento é "altamente desejável" ou "fundamental". A realidade delineada implica em reconhecer a prevalência de oclusopatias como um problema de saúde pública e na adoção de medidas para sua prevenção e tratamento, direcionadas aos escolares de doze anos de idade em Feira de Santana.

Diferenças na prevalência da oclusopatia entre os tipos de escola não foram identificadas, confirmando o que foi verificado por TOMITA (1996) e 
FRAZĀO et al. (2002), mas diferindo dos registros de SILVA DRAD et al. (1995).

Os dados descritos na literatura em relação ao sexo, em sua maioria, afirmam que o mesmo não exerce influência nos graus de oclusopatia (MASCARENHAS 1977; FRAZÃO et al. 2002; STIZ 2001), nesta pesquisa, diferenças estatísticas também não foram registradas.

Diferenças estatísticas em relação à etnia foram registradas somente para as escolas municipais. Este resultado discorda dos trabalhos de SILVA DRAD et al. (1995) e TOMITA (1996). No entanto, não há um consenso na literatura quanto a relação entre etnia e oclusopatias (FRAZÃO 1999). Este autor ressalta ainda que nos estudos sobre oclusopatias a etnia não deve ser considerada uma variável sem importância, devendo ser objeto de interesse e controle em estudos futuros.

A associação positiva entre a maior experiência de cárie e a maior prevalência de problemas de oclusão (FRAZÃO 1999), não foi confirmada neste trabalho (Figura 5), semelhante ao registrado por STIZ (2001).

A maioria das crianças, em todos os tipos de escola, não apresentou fluorose dentária e o percentual de escolares, com fluorose, foi superior aos encontrados em outros trabalhos na literatura (BRANDÃO et al. 2002; HEINTZE, BASTOS e BASTOS 1998; PATIÑO 2000; PEREIRA et al. 2001; RIORDAN e BANKS 1991). Particularmente, destaca-se o registro de casos de fluorose "moderada" e "severa" semelhante ao registrado por EI-NADEEF e HONKALA (1998) e MASSARO (2000); registro este não usual em regiões com água fluoretada, onde são esperados e considerados aceitáveis percentuais em torno de 10 a $15 \%$ de fluorose "muito leve" e "leve" (CURY 1989). CANGUSSU et al. (2002) relataram que já são encontradas freqüências mais altas que as esperadas, embora com poucos casos de maior severidade.

O estudo de CARDOSO, em 1999, realizado no Estado da Bahia, em dois municípios baianos, registrou percentuais superiores aos verificados neste trabalho, no entanto, contrariamente o autor não constatou casos de 
fluorose "severa". Ressalta-se que, no estudo citado, a prevalência foi alta apesar do acesso à água fluoretada ser diferente nas duas localidades onde o trabalho foi realizado.

É importante salientar que a prevalência e a severidade de fluorose verificada neste trabalho possivelmente não devem estar relacionadas especificamente ao consumo de água fluoretada, mas sim a outras formas de utilização do flúor. Isto se deve ao fato de que o período de risco para o desenvolvimento de fluorose dentária é a absorção de flúor pelo esmalte dental durante os primeiros anos de vida, especialmente quando a exposição começa ao nascimento, continuando durante mais de onze meses de idade para os molares permanentes, mais que um ano para os incisivos centrais superiores permanentes e mais que dois anos para os primeiros pré-molares permanentes, estendendo-se até os sete anos para os demais dentes (ISHII e SUCKLING 1991). Como a fluoretação da água de abastecimento público em Feira de Santana foi interrompida em 1987 e reativada em 1997, durante o período de risco ao desenvolvimento de fluorose dentária, as crianças examinadas não estavam expostas ao flúor proveniente da água de abastecimento.

Outro ponto importante, é que a fluorose dentária não é observada somente em comunidades com fluoretação das águas, mas também em áreas não fluoretadas, implicando em absorção de flúor de outras fontes que não a água (RIORDAN 1991; LEWIS e BANTING 1994; Den BESTEN 1999). Desta forma, estudos mais relacionados aos demais métodos de utilização tais como: suplementos com flúor, pastas dentais fluoretadas (início de utilização e deglutição em tenra idade), devem ser delineados para Feira de Santana a fim de avaliar a correlação entre a exposição total ao flúor e o escore de fluorose registrado. Essa necessidade se reveste de uma maior relevância ao considerar a reimplantação do flúor na água como fator adicional, bem como, ao fato de não estar sendo feita a vigilância dos teores de flúor na água do município. A necessidade do heterocontrole da concentração adequada de flúor nos sistemas públicos de abastecimento é enfatizada por vários autores e legalmente é obrigatória (CANGUSSU et al. 
2002; HEINTZE, BASTOS e BASTOS 1998; MASSARO 2000; NARVAI 2000; PEREIRA et al. 2001; SILVA MF de A 1997; SILVA CAL, ALVES e FREITAS 1998).

As diferenças observadas nos niveis de fluorose entre os tipos de escola podem estar relacionadas à utilização do flúor pelas crianças em casa e a correspondente supervisão desta utilização pelos pais. MALTZ e SILVA (2001) também registraram diferenças entre escolares de escolas públicas e privadas. No entanto, estas diferenças não foram observadas por SILVA DRAD et al. (1995).

A ausência de diferenças estatisticamente significativas dos dados de prevalência de fluorose entre os sexos foi constatada também nos trabalhos de PATIÑO (2001), RIORDAN, BANKS (1991), RIORDAN (1991) e CAPELLA et al. (1989). Contrariamente, FORNI (2000) constatou diferenças significativas nos municípios de Diadema e São Paulo.

Em relação à etnia, também não foram observadas diferenças estatisticamente significativas. Mas, FORNI (2000), após a análise dos resultados de levantamentos de fluorose dentária em vários municipios no Estado de São Paulo, destacou que as variáveis, sexo e etnia, tiveram resultados diferentes, de acordo com o local de estudo, possivelmente refletindo a distribuição da população em cada município, aspectos que necessitam confirmações.

O esmalte de dentes fluoróticos é hipomineralizado e por isso mais suscetivel a fraturas (FEJERSKOV et al 1994) e menos resistente ao processo de desmineralização, podendo desenvolver cárie com mais facilidade ou favorecer a alterações nas relações oclusais. No presente trabalho não foram constatadas associações entre o Índice de Fluorose e as demais condições estudadas: CPOD, CPI e DAI.

As questões referentes à ocupação dos pais dos escolares, grau de escolaridade e renda familiar parecem estar relacionadas visto que condições melhores de ocupação, escolaridade e renda concomitantemente foram registradas no grupo de pais das escolas particulares. Alguns 
trabalhos têm registrado correlação das condições sócio-econômicas e de escolaridade dos pais com o nivel de saúde bucal de seus filhos (FREIRE 2000; GONÇALVES, PERES e MARCENES (2002); PERES 2002). Verificar a existência destas correlações não foi objeto do presente trabalho.

Distribuições semelhantes de grau de instrução, renda familiar, atendimento odontológico no ano anterior e local do atendimento foram registradas por MALTZ e SILVA (2001).

As' diferenças entre índices segundo o tipo de escola só foram observadas na composição do índice CPOD, nos tipos de necessidades de tratamento, com exceção da indicação de coroa, no número de escolares segundo pior condição periodontal e no número médio de sextantes segundo condição periodontal por individuo. Essas diferenças possivelmente estão relacionadas a um melhor acesso dos escolares das escolas particulares aos serviços odontológicos e às informações sobre educação em saúde.

Quanto ao tempo de residência, é pertinente referir que os escolares examinados sejam considerados como representativos da população escolar do município, uma vez que a maioria residia no municipio por mais de onze anos. No entanto, em relação a fluorose dentária, um dado relevante e não obtido neste trabalho, seria verificar se no local de residência anterior das crianças, entre aquelas que residiam no município por um período inferior a este, houve exposição à água fluoretada ou a outros métodos sistêmicos de utilização do flúor. Essa investigação, de caráter individual para cada criança, comportaria um custo elevado e eficácia discutivel.

Quanto à fonte de água, o percentual menor de crianças da rede particular de ensino com utilização de outras fontes que não a rede de abastecimento público se justifica uma vez que é comum a escavação de poços artesianos em residências de maior nível sócio-econômico, devido à superficialidade do lençol freático em Feira de Santana. Isto também requer a realização do monitoramento dos teores de flúor nesta fonte alternativa de água. 
Sobre a condição de saúde bucal de seus filhos e a sua relação com a frequência escolar, nas escolas públicas a maior atribuição da condição "ruim" pelos pais pode estar relacionada ao fato destas crianças apresentarem um maior número de dentes cariados em relação às crianças das escolas particulares e também necessidades de tratamentos mais complexos, podendo ter exercido maior influência na falta da criança à escola.

A exclusão das crianças, nas escolas públicas, quanto ao acesso ao tratamento odontológico pode ser caracterizada pelo inexpressivo percentual de filiação a planos odontológicos e pelo baixo percentual de realização de tratamento no ano anterior. Quando o tratamento havia sido realizado, a procura por serviços públicos dos escolares das escolas públicas foi maior $e$ claramente inversa à procura por serviços particulares nas escolas particulares, mesmo tendo sido registrado nestas últimas uma maior filiação a planos odontológicos. A questão econômica mais uma vez parece estar atuando como um fator limitante ao acesso, visto que também uma menor renda familiar foi registrada para os pais das escolas públicas. Estes dados evidenciam a necessidade do fortalecimento do setor público odontológico no municipio para garantir a equidade e universalidade dos escolares e da população em geral quanto ao acesso e assistência.

PATUSSI (2000), investigando as desigualdades na distribuição da cárie dentária em escolares de doze anos, residentes em diferentes regiões socioeconômicas do Distrito Federal/Brasil - 1997, verificou que em regiōes de condiçōes socioeconômicas melhores a prevalência e a severidade da cárie foi menor, bem como o acesso ao tratamento odontológico foi diferente. BALDANI, NARVAI e ANTUNES (2002) também observaram correlação significativa entre o indice de cárie dentária aos doze anos em municipios do Estado do Paraná e vários indicadores de desenvolvimento social. 
O maior acesso a informações sobre educação em saúde bucal dos pais das escolas particulares possivelmente foi influenciado pela maior nivel de escolaridade identificado neste grupo de pais.

Os dados referentes ao uso tópico do flúor como método de prevenção instituido na escola destacam a seguinte questão: somente escolares que tiveram participaram do Programa Sorria Feira haviam referido a utilização do flúor; demonstrando a importância do programa e a relevância da sua expansão para a população de escolares em geral, de forma a assegurar o acesso igualitário nesse grupo populacional.

A freqüência da realização da limpeza bucal se distribuiu de forma homogênea entre os escolares dos diferentes tipos de escola, características diferentes foram visualizadas em relação ao método de higiene bucal utilizado, que demonstrou uma maior utilização de métodos alternativos pelos escolares de instituições particulares.

A maioria da amostra relatou utilizar dentifrício fluoretado com alta concentração de flúor, dados semelhantes aos de CARDOSO (1999). A ingestão de creme dental durante a escovação por crianças tem sido descrita na literatura, uma vez que na presente amostra, graus de fluorose dentária, "moderado" e "severo", foram registrados, o uso dos dentifrícios e sua deglutição devem ser investigados no município.

As respostas referentes ao consumo de peixe e chá foram pouco esclarecedoras, pesquisas melhor direcionadas a estas questões, com controle das variáveis de confundimento, sobre a ingestão de outros alimentos com flúor, do uso da suplementação com flúor e visando avaliar a exposição total ao flúor devem ser desenvolvidas para tentar identificar os fatores de risco envolvidos na prevalência de fluorose dentária observada.

O consumo de alimentos açucarados está diretamente relacionado à etiologia da cárie dental, em especial a sua freqüência como fator de risco na prevalência e severidade da doença (PERES 2002). Observou-se que as crianças das escolas particulares apresentaram um consumo mais freqüente de doces, o que diverge do relato BALDANI, NARVAI e ANTUNES (2002) de 
que populações mais pobres tendem a consumir mais açúcar. Certamente no presente trabalho a diferença se apresenta devido ao direcionamento dado à questão, na qual se perguntou sobre o uso de doces e guloseimas, e não sobre o consumo total de açúcar. CARDOSO (1999) registrou também alta freqüência do consumo de dieta cariogênica em Alagoinhas e Pojuca, municípios do Estado da Bahia. Possivelmente, a freqüência de consumo aqui registrada, tenha relação com hábitos dietéticos e culturais da região e precisam ser mais investigados para o direcionamento de campanhas educativas. 


\section{CONCLUSÕES}

A prevalência da cárie dentária nos escolares examinados de acordo com o tipo de escola foi baixa (CPOD médio: 1,89 nas escolas estaduais, 2,17 nas municipais e 2,39 nas particulares), com a polarização da prevalência em um menor grupo de crianças e demonstrando diferenças significativas na composição do CPOD entre os tipos de escola, onde o maior percentual de dentes não restaurados foi evidenciado nas escolas públicas. Em relação ao sexo não foram registradas diferenças significativas. O CPOD médio registrado para os escolares de acordo com o tipo de escola se encontra abaixo do valor três, proposto pela OMS para esta idade para o ano 2000.

A maioria dos dentes (mais de 90,0\%) dos escolares examinados, em todos os tipos de escola, não apresentou necessidades de tratamento e dentre os que apresentavam necessidades, o percentual maior foi registrado nas escolas estaduais e municipais.

A condição de saúde periodontal nos escolares examinados foi favorável, com número médio de sextantes sadios por indivíduo: 4,08(Municipais), 4,36(Estaduais) e 5,16(Particulares), sendo estes valores superiores à meta proposta pela OMS-FDI (1984) para esta faixa etária. Diferenças significativas entre os tipos de escola foram registradas. Os alunos das escolas particulares apresentaram melhores índices tanto em relação à severidade quanto à extensão da doença periodontal. As meninas exibiram condição periodontal mais favorável com diferença significativa nas escolas municipais, o que não ocorreu nas outras escolas.

A prevalência da oclusopatia foi alta em todos os tipos de escola (Estaduais: $55,2 \%$, Municipais: $47,7 \%$ e Particulares: $48,0 \%$, com a ocorrência de casos nas categorias "severa" e "incapacitante", e não apresentou diferença significativa entre os tipos de escola e sexo. Estes dados indicam a importância de se adotar medidas para a prevenção e tratamento da oclusopatia em Feira de Santana. 
Os dados sobre fluorose dentária caracterizaram uma prevalência mais alta (Estaduais: $45,6 \%$, Municipais: $36,5 \%$ e Particulares: $34,0 \%$ ) do que a esperada em regiões onde ocorre o uso de água de abastecimento fluoretada, diferenças significativas entre as escolas foram constatadas. Não foram identificadas diferenças estatísticas em relação ao sexo.

Em relação à etnia, só foram verificadas diferenças estatísticas, entre os tipos de escola, na distribuição do DAl para as escolas municipais, a qual pode ter sido conseqüente a alta prevalência da condição "normal" (60,7\%) em "negros".

Um estudo descritivo não permite inferir relações de causa-efeito das condições investigadas, mas indica a necessidade de pesquisar melhor as evidências exibidas nas distribuiçōes observadas, com um maior controle da variável etnia. Ressalta-se, neste estudo, a relevância da realização de futuras investigações sobre as possiveis correlaçōes entre as condiçōes sócio-econômicas e de escolaridade dos pais e as condições de saúde bucal das crianças.

Os dados remetem para a importância da programação de ações para a resolução das necessidades acumuladas especialmente nos escolares da rede pública, que demonstraram um deficiente acesso aos serviços odontológicos. Também exibem a importância de se elaborar programas de ações coletivas em saúde bucal centrados na estratégia da definição dos grupos de risco, o que não só otimizará recursos como poderá permitir a melhoria na intervenção em saúde bucal coletiva.

Em Feira de Santana, ações de vigilância da fluoretação da água de abastecimento público de acordo com o principio do heterocontrole, a incorporação do THD ao serviço público e a inserção do cirurgião-dentista no PSF, para a implantação de ações de educação em saúde bucal integradas com outros programas públicos de promoção de saúde e com a universidade, são fundamentais para controlar os fatores de risco relacionadas às doenças bucais e melhorar o perfil epidemiológico destas doenças nos escolares e na população em geral. 
Cabe destacar que a pesquisa fornece dados que permitem formular políticas de atenção ao escolar, sendo essa base objetiva de pesquisa condição necessária para a organização da assistência, mas, não suficiente porque outras variáveis do tipo - organização dos serviços, superação de dificuldades da cultura política partidária local, inclusão na política orçamentária, entre outras - poderão ou não, ser consideradas ou estar disponíveis para a formulação de políticas adequadas.

Para a implantação das políticas formuladas e a garantia dos princípios de universalidade, equidade e integralidade, princípios norteadores do Sistema Único de Saúde, são requeridas a mobilização/participação da sociedade, a continuidade das ações implementadas e a responsabilidade para com a qualidade de vida dos indivíduos/comunidade e a preservação do meio ambiente. 


\section{REFERÊNCIAS BIBLIOGRÁFICAS}

1. Ainamo J. Epidemiologia da doença periodontal. In: Lindhe J. Tratado de periodontologia clínica. Rio de Janeiro: Interamericana; 1985. p. $41-53$.

2. Al-Khateeb TL, Al-Marsafi Al, O'Mullane DM. Caries prevalence and treatment need amongst children in an Arabian community. Community Dent Oral Epidemiol 1991; 19: 277- 80.

3. Almeida ES de, Castro CGJ de, Vieira CAL. Distritos sanitários: concepção e organização. São Paulo: Faculdade de Saúde Pública USP;1998.O conceito de saúde e do processo saúde-doença; p.11 - 3.

4. Almeida Filho $\mathrm{N}$ de, Rouquayrol $\mathrm{MZ}$. Introdução à epidemiologia. Rio de Janeiro: Medsi; 2002.

5. Araújo MGM de. Ortodontia para clínicos: programa préortodôntico. $4^{a}$ ed. São Paulo: Santos; 1988.

6. Baldani MH, Narvai PC, Antunes JLF. Cárie dentária e condições sócioeconômicas no Estado do Paraná, Brasil, 1996. Cad Saúde Pública 2002; 18(3): 755-63.

7. Bastos R da S, Bijella VT, Bastos JR de M, Buzalaf MAR. Declínio de cárie dentária e incremento no percentual de escolares, de doze anos de idade, livres da doença, em Bauru, São Paulo, entre 1976 e 1995. Rev Fac Odontol Bauru 2002; 10(2): 75-80.

8. Beltrán-Aguilar ED, Griffin SO, Lockwood SA. Prevalence and trends in enamel fluorosis in the United States from the 1930s to the 1980s. JADA 2002; 133: 157 - 65 .

9. Borrell LN, Burt BA, Gillespie BW, Lynch J, Neighbors H. Periodontitis in the United States: beyond black and white. J Public Health Dent 2002; 62(2): $92-101$.

10. Bottan ER, Stker H, Reibnitz Júnior C, Gevaerd S, Campos ML. Educação e saúde bucal: avaliação da eficácia do programa 
implantado na rede municipal de ensino de Rio do Sul - SC. Alcance (Centro de ciências da saúde) 1999, ano VI (4): 67-72.

11. Brandão IMG, Peres AS, Saliba NA, Momias SAS, Prevalência de fluorose dentária em escolares de Marinópolis, São Paulo. Cad Saúde Pública 2002; 18(3): 877-81.

12. Bresolin D. Controle e prevenção da maloclusão. In: Pinto VG. Saúde bucal coletiva. $4^{a}$ ed. São Paulo: Livraria Santos; 2000. p.473-80.

13. Buendia OC. Situação atual da fluoretação de águas de abastecimento público no Estado de São Paulo-Brasil. Rev Saúde Pública 1983; 17 : 226-32.

14. Bulman JS, Osborn JF. Statistics in dentistry. $1^{\text {a }}$ ed. London: BDJ; 1989.

15. Buzalaf MAR, Cury JA, Whitford GM. Fluoride exposures and dental fluorosis: a literature review. Rev FOB 2001; 9(1/2): 1 - 10.

16. Cangussu MCT, Narvai PC, Fernandez RC, Djehizian V. A fluorose dentária no Brasil: uma revisão crítica. Cad Saúde Pública 2002; 18(1): 7- 15 .

17. Capella LF, Carcereri DL, Paiva SM de, Rosso RA, Paixão R de F, Saltori ED, Freitas ARR de, Zenkner JE do A, Barros Filho MA de. Ocorrência de fluorose dentária endêmica. RGO 1989; 37(5): 371-5.

18. Carranza Jr F. Periodontia clínica de Glickman. 5 $5^{\text {a }}$ ed. Rio de Janeiro: Guanabara; 1979.

19. Cardoso ACC. Fluoretação em águas de abastecimento público: a ocorrência de cárie e fluorose dentária em dois municípios no Estado da Bahia. Salvador; 1999. [Dissertação de Mestrado - Instituto de Saúde Coletiva - Universidade Federal da Bahia].

20. Carvalho J, Maltz M. Tratamento da doença cárie. In: ABOPREV. Promoção de Saúde Bucal. $1^{a}$ ed. São Paulo: Artes Médicas; 1997. p. 93-112. 
21. Castellanos RA. Aspectos epidemiológicos da cárie dental, em escolares brancos e não brancos, de ambos os sexos, internos em sete orfanatos da cidade de São Paulo, Brasil, em 1972. Rev Saúde Pública 1974; 8:51-62.

22. Castro ALS. Dois indices para medir cárie dental: o Índice Reversível de Cárie Dental (IRCD) e o Índice de Atividade de Cárie (IAC). Feira de Santana; 1998.[Dissertação de Mestrado Universidade Estadual de Feira de Santana].

23. Chaves MM. Odontologia Social. $3^{\text {a }}$ ed. São Paulo: Artes Médicas; 1986.

24. Chiapinotto GA. Etiologia e prevenção da doença periodontal. In Pinto VG. Saúde bucal coletiva. $4^{\mathrm{a}}$ ed. São Paulo: Livraria Santos; 2000 . p. 429-44.

25. Chioro A; Scaff, A . Saúde e cidadania: a implantação do sistema único de saúde. Disponivel em <URL: http: $/ / w w w . c o n s a u d e . c o m . b r / s u s . h t m>[1999$ nov 20]

26. Clark DC, Hann HJ, Williamson MF, Berkowitz J. Influence of exposure to various fluoride technologies on the prevalence of dental fluorosis. Community Dent Oral Epidemiol 1994; 22: 461 - 4 .

27. Cohen HDS, Fischer R, Mann J. Periodontal treatment needs and oral hygiene among Ethiopian immigrants. Int Dent J 1995; 45(3): 204-8.

28. Cury JA. Uso do flúor. In: Baratieri LN et al. Dentística: procedimentos preventivos e restauradores. $1^{\frac{a}{3}}$ ed. Rio de Janeiro: Santos/Quintessence; 1989. p. 43-67.

29. Cury JA. Controle químico da placa dental. In: ABOPREV. Promoção de Saúde Bucal. 1a ed. São Paulo: Artes Médicas; 1997. p. 129-40.

30. Cury JA . Cárie e creme dental. Jornal da ABOPREV 1998; Ano IX out: 02. 
31. Den BESTEN PK. Biological mechanisms of dental fluorosis relevant to the use of fluoride supplements. Community Dent Oral Epidemiol $1999 ; 27: 41-7$.

32. Dini EL. Changes in periodontal conditions of children and adolescents from Araraquara, Brazil: 1995 - 1998. Braz Dent J 2001; 12(1): 51-5.

33. Dini EL, Foschini ALR. Periodontal conditions in a 7-19 years old student population in Araraquara, São Paulo, Brasil, 1995. Cad Saúde Pública 1997; 13(2): 321-4.

34. Duckworth RM. The science behind caries prevention. Int Dent J 1993; 43(6) supl. 1: 529-39.

35. Duckworth RM, Morgan SN. Oral fluoride retention after use of fluoride dentifricies. Caries Res 1991; 25(2): 123-9.

36. El - Nadeef MAI, Honkala E. Fluorosis in relation to fluoride levels in water in central Nigeria. Community Dent Oral Epidemiol 1998; 26 : 26-30.

37. Escorel S. Exclusão social e saúde. Saúde em debate 1994; (43): 3843.

38. Federation Dentaire Internationale (FDI). Global goals for oral health in 2000. Int Dent J 1982; 32(1): 74-7.

39. Federation Dentaire Internationale (FDI). Nueva metodologia para evaluar las necessidades del tratamiento periodontal. Actual odontol $1984 ; 6(17):$ 43-8.

40. Fejerskov O, Manji F, Baelum V, Møller IJ. Fluorose dentária: um manual para profissionais da saúde. $1^{\text {a }}$ ed. São Paulo: Santos; 1994.

41. Fernandez RAC, Narvai PC, Frazão $P$, Martins JS, Coimbra MB, Medina MRJ, Mattos MGG, Gonzalez MHM, Scapolan OP, Batoni SZ, Pêra VLG. Levantamento epidemiológico em saúde bucal: Osasco - SP. São Paulo; 1999. [Relatório do Curso de Especialização Odontologia em Saúde Coletiva - Faculdade de Saúde Pública - USP]. 
42. Fitzgerald RJ, Keyes PH. Demonstration of the etiologic role of streptococci in experimental caries in the hamster. JADA 1960; 61: 24 -33 .

43. Flores-de-Jacoby L, Bruchmann S, Mengel R, Zafiropoulos GGK. Periodontal conditions in Rio de Janeiro City (Brazil) using the CPITN. Community Dent Oral Epidemiol 1991; 19: 127-8.

44. Forni TIB. Caracterização de levantamentos eoidemiológicos de fluorose dentária no Estado de São Paulo. São Paulo; 2000. [Dissertação de Mestrado - Faculdade de Saúde Pública/ USP].

45. Fratucci MVB. Alguns aspectos das condições de saúde bucal de uma população indígena guarani mbyá no município de São Paulo. São Paulo; 2000. [Dissertação de Mestrado - Faculdade de Saúde Pública-USP].

46. Frazão P. Epidemiologia da oclusão dentária na infância e os sistemas de saúde. São Paulo; 1999.[Tese de Doutorado - Faculdade de Saúde Pública-USP].

47. Frazão $P$, Narvai $P C$, Latorre $M$ do RD de $O$, Castellanos RA. Prevalência de oclusopatia na dentição decídua e permanente de crianças na cidade de São Paulo, Brasil, 1996. Cad Saúde Pública 2002; 18(5): 1197-205.

48. Freire $M$ do $\mathrm{CM}$, Melo RB de, Silva SA e. Dental caries prevalence in relation to socioeconomic status of nursery school children in Goiânia GO, Brasil. Community Dent Oral Epidemiol 1996; 24: 357-61.

49. Freire $M$ do $C M$, Pereira MF, Batista $S M$ de $O$, Borges $M$ do RS, Barbosa MI, Rosa AGF. Prevalência de cárie dentária e necessidades de tratamento em escolares de 6 a doze anos de idade, Goiânia, GO, Brasil 1994. Rev. Saúde Pública 1997, 31(1): 44-52.

50. Freire $M$ do $C M$, Pereira MF, Batista $S M$ de $O$, Borges $M$ do RS, Barbosa MI, Rosa AGF. Prevalência de cárie dentária e necessidades 
de tratamento em escolares de 6 a doze anos da rede pública de ensino. Rev. Saúde Pública 1999, 33(4): 385-90.

51. Freire $\mathrm{M}$ do $\mathrm{CM}$. Prevalência de cárie e fatores sócio-econômicos em pré-escolares - revisão de literatura. Rev Bras de Odontologia em Saúde Coletiva 2000; 1(1): 43-9.

52. Freysleben GR, Peres MA, Marcenes W. Prevalência de cárie e CPO-D médio em escolares de doze a treze anos de idade, nos anos de 1971 e 1997, região sul, Brasil. Rev. Saúde Pública 2000, 34(3): 304-8.

53. Frias AC. Estudo de confiabilidade do levantamento epidemiológico de saúde bucal: estado de São Paulo, 1998. São Paulo; 2000. [Dissertação de Mestrado - Faculdade de Saúde PúblicaUSP].

54. Galvão CAAN, Pereira CB, Bello DRM. Prevalência de maloclusões na América Latina e considerações antropológicas. Ortodontia 1994; 27(1): 51-7.

55. Garrafa V. Saúde bucal e cidadania. Saúde em debate 1993;(41):50-7.

56. Geddes DAM, Rølla G. Fluoride in saliva and dental plaque. In: Ekstrand J, Fejerskov O, Silverstone LM. Fluoride in dentistry. Copenhagen; 1988. p. 60-86.

57. Gjermo P, Bellini HT, Marcos B. Application of the Community Periodontal Index of Treatment Needs (CPITN) in a population of Young Brazilians. Community Dent Oral Epidemiol 1983;11(6):342-6.

58. Gjermo P. Goals for periodontal health and acceptable levels of disease: means and methods in community strategies. In: Frandsen A. Public health aspects of periodontal disease - proceedings of a workshop in Copenhagen. Chicago: Quintessence; 1984. p. 121-33.

59. Gonçalves ER, Peres MA, Marcenes W. Cárie dentária e condições sócio-econômicas: um estudo transversal com jovens de 18 anos de Florianópolis, Santa Catarina, Brasil. Cad Saúde Pública 2002; 18(3): 699-706. 
60. Graber TM. Ortodoncia: teoría e práctica. $3^{\text {a }}$ ed. México: Interamericana; 1974.

61. Groeneveld A, Van Eck AAMJ, Backer Dirks O. Fluoride in caries prevention: is the effect pre- or post-eruptive? J. Dent. Res. Switzerland 1990; Special Issue. (69): 751-5.

62. Heintze SD, Bastos JRM, Bastos R. Urinary levels and prevalence of dental fluorosis in three Brazilian cities with different fluoride concentrations in the drinking water. Community Dent Oral Epidemiol 1998; 26: 316-23.

63. Interlandi S. Ortodontia: bases para a iniciação. $4^{a}$ ed. São Paulo: Artes Médicas; 1999.

64. Instituto Brasileiro de Geografia e Estatística (IBGE). Microdados da amostra do censo demográfico de 1991, versão 1 [CD rom]. Rio de Janeiro: IBGE; 1996.

65. Instituto Brasileiro de Geografia e Estatística (IBGE). Censo populacional 2000. Disponivel em <URL: http://www1.ibge.gov.br> [2002 nov 30].

66. Ishii T, Suckling G. The severity of dental fluorosis in children exposed to water with a high fluoride content for various periods of time. J. Dent Res 1991; 70(6): 952 - 6.

67. Jenkis WMM. The prevention and control of chronic periodontal disease. In: Murray JJ. The prevention of dental disease. 2nd edition. New York: Oxford, 1989. p. 327-72.

68. Keyes $\mathrm{PH}$. The infectious and transmissible nature of experimental dental caries. Archs Oral Biol 1960; 1: 304- 20.

69. Köhler B, Bratthall D. Intrafamilial levels of Streptococcus mutans and some aspects of the bacterial transmission. Scand J Dent Res 1978; 86: $35-42$. 
70. Köhler B et al. Effect of the caries preventive measures on Streptococcus mutans and Lactobacilli in selected mothers. Scand J Dent Res 1982; 90: 102 - 8 .

71. Köhler B et al. Preventive measures in mother infuence the establishment of the bacterium Streptococcus mutans in their infants. Archs Oral Biol 1983; 28: $225-31$.

72. Krasse, B. Risco de cáries: guia prático para controle e assessoramento. $2^{\text {a }}$ ed. São Paulo: Quintessence, 1988.

73. Lagerlöf F, Oliveby A. Caries-protective factors in saliva. Adv. Dent. Res 1994; 8(2): 229-38.

74. Larsen MJ, Bruun C. Esmalte/saliva: reações químicas inorgânicas. In: Thylstrup A, Fejerskov O. Tratado de cariologia. $1^{1}$ ed. Rio de Janeiro: Cultura Médica; 1988. p. 169-93.

75. Lascala NT, Moussali NH. Periodontia clínica. São Paulo: Artes Médicas; 1981.

76. Lewis DW, Banting DW. Water fluoridation: current effectiveness and dental fluorosis. Community Dent Oral Epidemiol 1994; 22: 153 - 8.

77. Levy SM. A review of fluoride intake from fluoride dentifrice. J. Dent Child 1993; Mar/Apr: 115-24.

78. Lindhe J. Tratado de periodontologia clínica. $1^{\underline{a}}$ ed. Rio de Janeiro: Interamericana; 1985

79. Locker D, Clarke M, Murray H. Oral health status of Canadian-born and immigrant adolescents in North York, Ontario. Community Dent Oral Epidemiol 1988; 26: 177-81.

80. Löe $H$, Theilade $E$, Jensen SB. Experimental gingivitis in man. $J$ of Periodontology 1965; 36: $177-87$.

81. Loesche WJ. Cárie dental: uma infecção tratável. $1^{\text {a }}$ ed. Rio de Janeiro: Cultura Médica; 1993. 
82. Loretto NRM, Seixas ZA, Jardim MC, Brito RL. Cárie dentária no Brasil: alguns aspectos sociais, políticos e econômicos. Rev ABO Nac 2000; 8(1): 45-9.

83. Luiz RR, Magnanini MMF. O tamanho da amostra na pesquisa odontológica. Ver Bras Odont Saúde Coletiva 2001; 2(1): 55 - 65.

84. Maltz M, Carvalho J. Diagnóstico da doença cárie. In: ABOPREV. Promoção de Saúde Bucal. $1^{\underline{a}}$ ed. São Paulo: Artes Médicas; 1997. p. 69-91.

85. Maltz M. Cárie Dental: fatores relacionados. In: Pinto VG. Saúde bucal coletiva. $4^{a}$ ed. São Paulo: Santos; 2000. p. 319-39.

86. Maltz $M$, Silva BB e. Relação entre cárie, gengivite e fluorose e nivel socioeconômico em escolares. Rev Saúde Pública 2001; 35(2): 170-6.

87. Mandel ID. Caries prevention - current strategies, new directions. JADA 1996; 127: 1477-88.

88. Marcenes W, Bönecker MJS. Aspectos epidemiológicos e sociais das doenças bucais. In: EAP - APCD. Promoção de saúde bucal na clínica odontológica. Buischi $Y$ de P. $1^{\underline{a}}$ ed. São Paulo: Artes Médicas; 2000. v. 22. p. 73-98.

89. Marques RA de A. Condições de saúde periodontal no municipio de São Paulo em 1986 e 1998. São Paulo; 2000. [Dissertação de Mestrado - Faculdade de Saúde Pública - USP].

90. Martildes MLR, Castellanos RA, Robles LP. Prevalência de má oclusão em escolares de doze anos de idade de São José dos Campos, 1991. Rev Saúde Esc 1992; 2(3/4): 112-6.

91. Martildes MLR, Crisóstomo FP, Oliveira AWS de. Avaliação da prevalência de cárie dental em escolares de Icó, Ceará, Brasil, após seis anos de fluoretação das águas de abastecimento público. Divulgação em Saúde para Debate 1995; (10): 38-42. 
92. Mascarenhas SC. Freqüência de má oclusão em escolares de ambos os sexos, na faixa etária de 11 a doze anos, residentes no municipio de Palhoça, SC. Ortodontia 1977; 10(2): 99-105.

93. Massaro RBA. Prevalência de fluorose dentária em pré-escolares e escolares participantes do Programa de Promoção de Saúde Bucal da Prefeitura do Município de Osasco. São Paulo; 2000. [Dissertação de Mestrado - Faculdade de Saúde Pública/USP].

94. Maxado F. Qual é a data mais importante de Feira de Santana? Jornal Noite e Dia Feira de Santana (BA) jun 16; Ano II(88): 4.

95. Mendes EV. Uma agenda para a saúde. São Paulo: Hucitec; 1996.

96. Microsoft Corporation. Microsoft Excel. [Programa de computador].Versão 7.0. (New York): MapInfo Corporation; 2000.

97. Ministério da Saúde do Brasil. Levantamento epidemiológico em saúde bucal: Brasil, zona urbana, 1986. Brasilia: Ministério da Saúde; 1988.

98. Ministério da Saúde do Brasil. Política nacional de saúde bucal: princípios, objetivos, prioridades. Brasilia: Ministério da Saúde; 1989a.

99. Ministério de Saúde do Brasil/ Secretaria Nacional de Saúde e Vigilância Sanitária. Portaria no 22 de 20 de dezembro de 1989 sobre obrigatoriedade de flúor nos dentifrícios nacionais.1989b.

100. Ministério de Saúde do Brasil / Fundação Nacional de Saúde. Resolução 196/96: Diretrizes e normas regulamentadoras de pesquisas envolvendo seres humanos: Conselho Nacional de Saúde; Informe Epidemiológico do SUS, Ano V, (2): Abr./Jun. 1996.

101. Ministério da Saúde do Brasil. Levantamento epidemiológico em saúde bucal: Cárie dental, Capitais, 1996. Disponivel em <URL: htpp://www.saúde.gov.br.htm>, [2001 mar 30]. 
102. Ministério da Saúde do Brasil. DATASUS: Informações técnicas de estados e municípios período 2000. Disponivel em <URL: htpp://www.saúde.gov.br/datasus.htm>, [2002 nov 30].

103. Ministério da Saúde do Brasil. Projeto Saúde Bucal 2000.Brasilia: Ministério da Saúde/Área Técnica de Saúde Bucal; 2000.

104. Morais ND de, Lenza MA, Freire $M$ do $C M$. Prevalência de cárie em escolares de 6 a doze anos da rede pública de ensino do municipio de Dom Aquino - MT. Rev Bras Odont Saúde Coletiva 2000; 1(2): 45-9.

105. Moreira Ben-HW, Pereira AC, Oliveira SP. Avaliação da prevalência de cárie dentária em escolares de localidade urbana da região sudeste do Brasil. Rev Saúde Pública 1996; 30(3): 280-4.

106. Nadanovsky P, Sheiham A. Relative contribution of dental services to the changes in caries levels of 12-year-old children in 18 industrialized countries in the 1970s and early 1980s. Community Dent Oral Epidemiol 1995; 23: 331-9.

107. Narvai PC. Fluoretação da água: heterocontrole no município de São Paulo no periodo 1990-1999. Rev Bras Odont Saúde Coletiva 2000; 1(2): 50-6.

108. Narvai PC. Odontologia e saúde bucal coletiva. $2^{a}$ ed. São Paulo: Hucitec; 2002.

109. Narvai PC. Há metas em saúde bucal? Disponivel em <URL: htpp://www.jornal do site.com.Br/arquivo/anteriores/artcapel51.htm>, [2003 jan 05].

110. Narvai PC, Fernandes RAC. Levantamento Epidemiológico em saúde bucal: estado de São Paulo, 1998. Jornal do COSEMS 1999 set (7): 04.

111. Narvai $P C$, Castellanos RA, Frazão $P$. Prevalência de cárie em dentes permanentes de escolares do Município de São Paulo, SP, 1970-1996. Rev Saúde Pública 2000; 34(2): 196-200. 
112. Narvai PC, Forni TIB, Junqueira SR, Cury JA, Castellanos RA, Soares $\mathrm{M}$ da $\mathrm{C}$. Uso de produtos fluorados conforme o risco de cárie dentária: uma revisão crítica. Revista da APCD 2002; 56(2): 101-7.

113. Newbrun E. Current regulations and recommendations concerning water fluoridation, fluoride supplements and topical fluoride agents. $\mathrm{J}$ Dent Res 1992; 71(5): 1255 - 65.

114. Normando ADC, Araújo IC de. Prevalência de cárie dental em uma população de escolares da Região Amazônica. Rev Saúde Pública 1990; 24(4): 294-9.

115. Oliveira AGR da C, Unfer B, Costa I do CC, Arcieri RM, Guimarães LOC, Saliba NA. Levantamentos epidemiológicos em saúde bucal: análise da metodologia proposta pela Organização Mundial da Saúde. Rev Bras Epidemiol 1998; 1(2): 177 - 89.

116. Øgaard B, Seppä L, Rølla G. Professional topical fluoride applications clinical efficacy and mechanism of action. Adv Dent Res 1994; 8(2): 190-201.

117. Opperman RV, Rösing CK. Prevenção e tratamento das doenças periodontais. In: In: ABOPREV. Promoção de Saúde Bucal. $1^{\text {a }}$ ed. São Paulo: Artes Médicas; 1997. p. 255-82.

118. Orland FJ, Blayney JR, Harrison RW, Reyniers JA, Trexler PC, Wagner $M$, Gordon H, Luckey TD. Use of the germfree animal techinic in the study of the experimental dental caries. J Dent Res 1954; 33: 147 - 74.

119. Patiño JSR. Prevalência de cárie dentária e fluorose dentária em escolares de 5 a doze anos, matriculados em escolas públicas e privadas do município de Camboriú, SC, 2000. São Paulo; 2001. [Dissertação de Mestrado - Faculdade de Saúde Pública/USP].

120. Patussi MA. As desegualdades na distribuição da cárie dentária em escolares de doze anos residentes em diferentes regiōes sócioeconômicas do Distrito Federal, Brasil, 1997. Rev Bras Odont Saúde Coletiva 2000; 1(1): 19-28. 
121. Pereira AC, Mialhe FL, Bianchini $F L$ de $C$, Meneghim $M$ de $C$. Prevalência de cárie e fluorose dentária em escolares de cidades com diferentes concentrações de flúor na água de abastecimento. Rev Bras Odont Saúde Coletiva 2001; 2(1): 34-9.

122. Pereira MG. Epidemiologia: teoria e prática. Rio de Janeiro: Guanabara Koogan, 1995.583 p. p.358 - 76.

123. Peres MA de A, Narvai PC, Calvo MCM. Prevalência de cárie dentária em crianças aos doze anos de idade, em localidades do Estado de São Paulo, Brasil, período 1990 - 1995. Rev. Saúde Pública 1997; 31(6): $594-600$.

124. Peres MA de A. Determinantes sociais e biológicos do período perinatal e da primeira infância na prevalência e severidade da cárie dentária em crianças de 6 anos de idade. São Paulo; 2002. [Tese de Doutorado - Faculdade de Saúde Pública-USP].

125. Pilot $T$, Barmes DE, Leclercq MH, McCombie BJ, Sardo Infirri J. Periodontal conditions in adolescents, $15-19$ years of age: na overview of CPITN data in the WHO Global Oral Data Bank. Community Dent Oral Epidemiol 1987; 15: 336-8.

126. Pinto JAL. Origem e desenvolvimento de Feira de Santana. Jornal Noite e Dia Feira de Santana (BA) jun 16; Ano II(88): 2.

127. Pinto VG. Saúde bucal: panorama internacional. $1^{\text {a }}$ ed. Brasília: Ministério da Saúde, Secretaria Nacional de Programas Especiais de Saúde, Divisão Nacional de Saúde Bucal; 1990.

128. 39.Pinto VG. Saúde bucal: odontologia social e preventiva. $3^{\text {a }}$ ed. São Paulo: Santos; 1992.

129. Pinto VG. A Odontologia no município: guia para organização de serviços e treinamento a nível local. $1^{2}$ ed. Porto Alegre: RGO; 1996.

130. Pinto VG. Epidemiologia das doenças bucais no Brasil. In: ABOPREV. Promoção de Saúde Bucal. 1ª ed. São Paulo: Artes Médicas; 1997. p. 29-41. 
131. Pinto VG. Saúde bucal coletiva. $4^{\mathrm{a}}$ ed. São Paulo: Livraria Santos; 2000.

132. Prefeitura Municipal de Feira de Santana (PMFS)/Secretaria Municipal de Saúde (SMS). Plano municipal de saúde de Feira de Santana. Feira de Santana; 1997.

133. Prefeitura Municipal de Feira de Santana (PMFS)/Secretaria Municipal de Saúde (SMS). Relatório de atividades do programa de saúde bucal Sorria Feira. Feira de Santana; 2000.

134. Prefeitura Municipal de Feira de Santana (PMFS)/Secretaria Municipal de Saúde (SMS). Plano municipal de saúde de Feira de Santana. Feira de Santana; 2002a.

135. Prefeitura Municipal de Feira de Santana (PMFS)/Secretaria Municipal de Saúde (SMS). Relatório mensal da Divisão Odontológica de novembro de 2002. Feira de Santana; 2002b.

136. Proffit WR. Ortodontia contemporânea. $1^{\mathrm{a}}$ ed. São Paulo: Pancast; 1991.

137. Queiroz CMB. Qualidade de vida e políticas públicas no município de Feira de Santana - Bahia. São Paulo; 2002. [Tese de Doutorado Faculdade de Saúde Pública-USP].

138. Ramfjord SP, Ash MM. Periodontologia e periodontia: teoria e prática moderna. $1^{\underline{a}}$ ed. São Paulo: Santos; 1991.

139. Riordan PJ. Dental caries and fluoride exposure in Western Australia. J Dent Res 1991; 70(7): 1029 - 34 .

140. Riordan PJ, Banks JÁ. Dental fluorosis and fluoride exposure in Western Austrália. J Dent Res 1991; 70(7): 1022 - 8.

141. Ripa LW. A critique of topical fluoride methods (dentifrices, mouthrinses, operator- and self applied gels) in an era of decreased caries and increased fluorosis prevalence. J Public Health Dent 1991; 51(4): 23-41. 
142. Rølla G. Interaction of monofluorophosphate with plaque and saliva. Caries Res 1983; 17(5) Suppl. 1: 91-101.

143. Rølla $\mathrm{G}$. On the role of calcium fluoride in the cariostatic mechanism of fluoride. Acta Odontol Scand 1988; 46: 341-5.

144. Rouquayrol MZ. Epidemiologia \& Saúde. $4^{\mathrm{a}}$ ed. Rio de Janeiro: Medsi; 1994.

145. Sales-Peres SH de C, Bastos JR de M. Perfil epidemiológico de cárie dentária em crianças de doze anos de idade, residentes em cidades fluoretadas e não fluoretadas, na Região Centro-Oeste do Estado de São Paulo, Brasil. Cad Saúde Pública 2002; 18(5): 1281 -88.

146. Sampaio FC, Nazmul Hossain ANM, von der Fehr FR, Arneberg P. Dental caries and sugar intake of children from rural areas with different water fluoride levels in Paraíba, Brazil. Community Dent Oral Epidemiol 2000; 28: $00-00$.

147. Santos NCN, Santos LD, Silva MDV, Duarte PCT, Scavuzzi AIF. Avaliação da presença de placa visível e ICNTP em crianças de 03 a 05 anos na cidade de Feira de Santana. Feira de Santana; 1999. [Monografia de conclusão do Curso de Odontologia da Universidade Estadual de Feira de Santana].

148. Santos R de $M$, Pordeus IA, Ferreira RC. Distribuição da cárie dentária nos usuários do SUS em Belo Horizonte - um estudo de prevalência. Rev Bras Odont Saúde Coletiva 2000; 1(1): 63-73.

149. Secretaria de Educação e Cultura(SEC), MEC/INEP. Dados do Censo Escolar 2000. Disponivel em <URL: htpp://www.inep.gov.Br/estatísticas/números/BA01.htm>, [2001 mar 30].

150. Serviço Social da Indústria - SESI. Estudo epidemiológico sobre prevenção da cárie dental em crianças de 3 a 14 anos. Serviço Social da Indústria, Departamento Nacional. Brasília; 1995. 
151. Shanley DB, Ahern FM. Periodontal disease and the influence of socioeducational factors in adolescents. In: Frandsen A. Public health aspects of periodontal disease - proceedings of a workshop in Copenhagen. Chicago: Quintessence; 1984. p. 109-20.

152. Shaw WC. Dentofacial irregularities. Community Oral Health 1997; 104-11.

153. Sheiham A. A determinação de necessidades de tratamento odontológico: uma abordagem social. In: Pinto VG. Saúde bucal coletiva. $4^{\mathrm{a}}$ ed. São Paulo: Livraria Santos; 2000. p. 223-50.

154. Shellis RP, Duckworth RM. Studies on the cariostatic mechanisms of fluoride. Int Dent J 1994; 44(3) supl 1: 263-73.

155. Silva CAL da, Alves TDB, Freitas VS. Sistema de vigilância sanitária da fluoretação em águas de abastecimento público de Feira de Santana. Feira de Santana; 1998. [Projeto de extensão da Universidade Estadual de Feira de Santana].

156. Silva CHT, Araújo TM. Prevalência de más oclusões em escolares na Illha do Governador, Rio de Janeiro. Parte 1: Classes I, II e III e mordida cruzada. Ortodontia 1983; 16(3): 10-6.

157. Silva DRAD, Silva ELLG, Covello L, Sartori LC, Marques RA de A, Carneiro RM do V, Forni RCC, Forni TIB, Matos TCD, Silva VLG da, Fernandez RAC, Narvai PC. Levantamento epidemiológico em saúde bucal: Santos - SP. São Paulo; 1995. [Relatório do Curso de Especialização Odontologia em Saúde Coletiva - Faculdade de Saúde Pública - USP].

158. Silva MF de A. Flúor sistêmico: aspectos básicos, toxicológicos e clínicos. In: ABOPREV. Promoção de Saúde Bucal. $1^{a}$ ed. São Paulo: Artes Médicas; 1997. p. 141-65.

159. Silva MF de A. Prevenção da cárie dental. In: Pinto VG. Saúde Bucal Coletiva. $4^{\mathrm{a}}$ ed. São Paulo: Santos; 2000. p. 353-401. 
160. Silva NN da. Amostragem probabilistica: um curso introdutório. São Paulo: Edusp; 1998.

161. Silva Filho OG, Freitas SF, Cavassan AO. Prevalência de oclusão normal e má oclusão em escolares da cidade de Bauru. Parte II: influência da estratificação sócio-econômica. Rev Odontol Univ São Paulo 1990; 4(3): 189-96.

162. Songpaisan $Y$, Davies GN. Periodontal status and treatment needs in the Chiangmai/Lamphun provinces of Thailand. Community Dent Oral Eipemiol 1989; 17: $196-9$.

163. Souza JMP de, Arrillaga AN, Ochoa FV, Rocha O. Prevalência da cárie dental em brancos e não brancos. Rev Saúde Pública 1967; 1(1): 38 43.

164. Statistical Package for Social Sciences - SPSS for Windows. [Programa de Computador]. Version 9.0. SPSS Inc; 1998.

165. Stiz AL. Prevalência da doença periodontal e da má oclusão dentária em escolares de 5 a doze anos de idade de Camboriú SC, 2000. São Paulo; 2001. [Dissertação de Mestrado - Faculdade de Saúde Pública-USP].

166. Tatevossian A. Fluoride in dental plaque and its effects. J Dent Res 1990; 69 Special Issue: 645-52.

167. Thylstrup A, Fejerskov O. Tratado de Cariologia. $1^{\underline{a}}$ ed. Rio de Janeiro: Cultura Médica; 1988.

168. Tinoco BEM, Tinoco NMB. Diagnóstico e prevenção das doenças periodontais. In: EAP - APCD. Promoção de saúde bucal na clínica odontológica. Buischi Y de P. 1ª ed. São Paulo: Artes Médicas; 2000. v. 22. p. 99-124.

169. Tomita NE, Bijella VT, Lopes ES, Bijella MFTB, Abdo RCC. Prevalência de cárie dentária em crianças da faixa etária de 0 a 6 anos em creches de Bauru e São Paulo. Revista da FOB 1994; 2(3): 26-33. 
170. Tomita NE. Relação entre determinantes sócio-econômicos e hábitos bucais: influência na oclusão de pré-escolares de Bauru SP, Brasil. Bauru, 1996. [Tese de Doutorado - Faculdade de Odontologia de Bauru - USP]

171. Tomita NE, Bijella VT, Lopes ES, Franco LJ. Prevalência de cárie dentária em crianças da faixa etária de 0 a 6 anos matriculadas em creches: importância de fatores socioeconômicos. Rev Saúde Pública 1996; 30(5): 413-20.

172. Tomita NE, Nadanovsky P, Vieira ALF, Lopes ES. Preferências por alimentos doces e cárie dentária em pré-escolares. Rev Saúde Pública 1999; 33(6): 542-6.

173. Traebert J, Suárez CS, Onofri DA, Marcenes W. Prevalência e severidade de cárie dentária e necessidade de tratamento odontológico em pequenos municipios brasileiros. Cad Saúde Pública 2002; 18(3): 817-21.

174. Uchoa HW, Saliba NA. Prevalência de fluorose dental na cidade de Pereira Barreto. Bol Serv Odont Sanit 1970; 6(3): 11-6.

175. Universidade Estadual de Feira de Santana (UEFS). Processo de recredenciamento: relatório 5 , estrutura acadêmica - extensão 1996/2000. Feira de Santana; 2001.

176. Universidade de São Paulo - Faculdade de Saúde Pública. Núcleo de Estudos e Pesquisas de Sistemas de Saúde. Secretaria Estadual de Saúde de São Paulo. Levantamento epidemiológico da cárie dentária, oclusopatias e fluorose dentária em crianças de 5 a doze anos de idade, em escolas públicas e privadas do município de São Paulo, em 1996. São Paulo; 1997. [Relatório técnico].

177. Universidade de São Paulo/Faculdade de Saúde Pública. Guia de apresentação de teses. São Paulo: Centro de Informação e Referência em Saúde Pública; 1998. 
178. Universidade de São Paulo (USP) - Faculdade de Saúde Pública (FSP)/ Secretaria Estadual de Saúde - SP. Levantamento das condições de saúde bucal - Estado de são Paulo 1998 . Caderno de Instruções. São Paulo; 1998.

179. Universidade de São Paulo - Faculdade de Saúde Pública. Núcleo de Estudos e Pesquisas de Sistemas de Saúde. Secretaria Estadual de Saúde de São Paulo. Relatório final do Levantamento epidemiológico em saúde bucal: Estado de São Paulo, 1998. Disponivel em <URL: htpp://www.saude.sp.gov/saúde bucal. htm>, [2001 abr 13].

180. Universidade de São Paulo (USP) - Universidade Estadual de Feira de Santana (UEFS). Convênio de cooperação técnica celebrada entre a Universidade Estadual de Feira de Santana e a Universidade de São Paulo. São Paulo; 1999.

181. Viegas AR. Odontologia sanitária: aspectos preventivos da cárie dentária. São Paulo: Libris; 1961.

182. Viegas $Y$, Viegas $A R$. Análise dos dados de prevalência de cárie dental na cidade de Campinas, SP, Brasil, depois de dez anos de fluoração da água de abastecimento público. Rev Saúde Pública 1974; 8: 399409.

183. Viegas $Y$, Viegas $A R$. Análise dos dados de prevalência de cárie dental na cidade de Barretos, SP, Brasil, depois de dez anos de fluoração da água de abastecimento público. Rev Saúde Pública 1985; 19: 287-99.

184. Villa $A E$, Guerrero S, Icaza G, Villalobos J, Anabalón M. Dental fluorosis in Chilean children: evaluation of risk factors. Community Dent Oral Epidemiol 1998; 26: 310-5.

185. Weyne S. de C. Cariologia. In: Baratieri LN et al. Dentística: procedimentos preventivos e restauradores. $1^{\text {a }}$ ed. Rio de Janeiro: Santos/Quintessence; 1989. p. $1-42$. 
186. Weyne S. de C. Construção do paradigma de promoção de saúde: um desafio para as novas gerações. In: ABOPREV. Promoção de Saúde Bucal. $1^{a}$ ed. São Paulo: Artes Médicas; 1997. p. 2-26.

187. Whitford GM. The physiological and toxicological characteristics of fluoride. J Dent Res 1990; 69: 539-557.

188. World Health Organization (WHO). Oral health surveys, basic metods. 3th edition. Geneva: WHO; 1987.

189. World Health Organization. Oral health surveys, basic metods. 4th edition. Geneva: WHO; 1997.

190. Zanetti CHG, Lima MAU, Ramos L, Costa MABT. Em busca de um paradigma de programação local em saúde bucal mais resolutivo no SUS. Divulgação em Saúde para Debate, (CEBES), 1996; (13): 1835. 
ANEXOS 
ANEXO1 - Tamanho da amostra para o caso de uma média com precisão de $10 \%$ e confiança de $95 \%$.

\begin{tabular}{|c|c|c|c|c|c|c|c|c|c|c|c|}
\hline \multirow{2}{*}{$\begin{array}{l}\text { Desvio } \\
\text { Padrão }\end{array}$} & \multicolumn{11}{|c|}{ CPOD Média } \\
\hline & 0,5 & 1,0 & 2,0 & 3,0 & 4,0 & 5,0 & 6,0 & 7,0 & 8,0 & 9,0 & 10,0 \\
\hline 0,25 & 96 & 24 & 6 & * & * & * & * & * & * & $\star$ & \\
\hline 0,5 & 384 & 96 & 24 & 11 & 6 & * & * & * & * & * & * \\
\hline 1,00 & 1537 & 384 & 96 & 43 & 24 & 15 & 11 & 8 & 6 & 5 & * \\
\hline 1,50 & - & 600 & 216 & 96 & 54 & 35 & 24 & 18 & 13 & 11 & 9 \\
\hline 2,0 & - & 864 & 384 & 171 & 96 & 61 & 43 & 31 & 24 & 19 & 15 \\
\hline 2,50 & - & 1537 & 600 & 267 & 150 & 96 & 67 & 49 & 37 & 30 & 24 \\
\hline 3,0 & - & 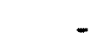 & 864 & 384 & 216 & 138 & 96 & 71 & 54 & 43 & 35 \\
\hline 4,00 & - & - & 1537 & 683 & 384 & 246 & 171 & 125 & 96 & 76 & \\
\hline
\end{tabular}

Fonte: PINTO, V. G. A odontologia no município: guia para organização de serviços e treinamento de profissionais a nivel local. Porto Alegre: RGO, 1996. 235p. p. 244.

Notas: * corresponde a valores inferiores a 5;

- representa valores inexistentes ou de rara concretização pela não correspondência entre o Desvio padrão e a respectiva média. 


\section{ANEXO 2}

\section{Formulário para os pais:}

INTRODUÇÃO: Nesta pesquisa estamos entrevistando os pais com a finalidade de investigar as condições de saúde bucal de seu filho(a). Não há resposta certa ou errada. Por favor, sinta-se à vontade, responda como quiser e o que você não entender pergunte. Para o preenchimento coloque no quadrinho da segunda coluna o número correspondente a sua resposta

\begin{tabular}{|c|c|}
\hline 1. data de nascimento da criança & $\begin{array}{l}\mathrm{V} .1 . \\
\text { i........ }\end{array}$ \\
\hline 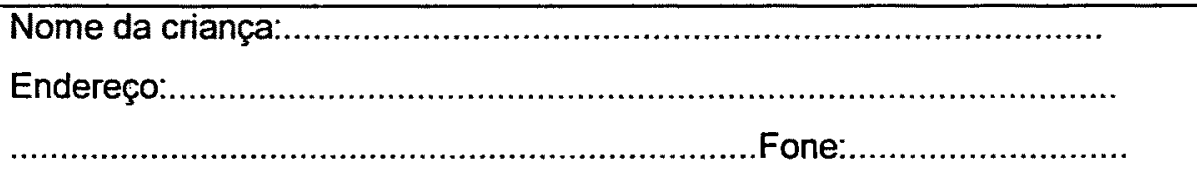 & \\
\hline 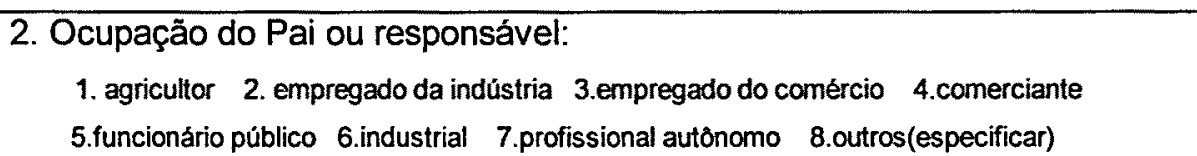 & V.2. \\
\hline 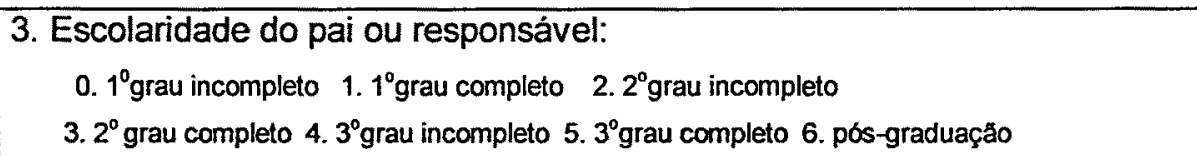 & V.3. \\
\hline $\begin{array}{l}\text { 4. Renda familiar: } \\
\begin{array}{lll}\text { 1. até } 01 \text { salário minimo } & \text { 2. de } 01 \text { a } 02 \text { salários mínimos } & 3 \text {. de } 02 \text { a } 03 \text { salários mínimos } \\
\text { 4. de } 03 \text { a } 05 \text { salários minimos } & 5 \text {. mais que } 05 \text { salários mínimos }\end{array}\end{array}$ & V.4. \\
\hline $\begin{array}{l}\text { 5. Tempo de Residência em Feira de Santana: } \\
\begin{array}{llll}\text { 1. mora } 11 \text { ou mais anos } & \text { 2. mora de } 6 \text { a } 10 \text { anos } & \text { 3. mora de } 0 \text { a } 5 \text { anos }\end{array}\end{array}$ & V.5. \\
\hline $\begin{array}{l}\text { 6. Fonte de água para beber na residência: } \\
\text { 1. água encanada do serviço de abastecimento } 2 \text {.outra fonte }\end{array}$ & V.6. \\
\hline $\begin{array}{l}\text { 7. Você acha que a saúde bucal de seu(ua) filho(a) está: } \\
\begin{array}{lllll}\text { 1. Excelente } & \text { 2. Muito boa } & \text { 3. Boa } & \text { 4. Razoável } & 5 . \text { Ruim }\end{array}\end{array}$ & $\overline{V .7 .}$ \\
\hline $\begin{array}{l}\text { 8. Os problemas de saúde bucal de seu(ua) filho(a) têm causado alguma } \\
\text { dificuldade no sua freqüência escolar? } \\
\text { 0. Nåo } 1 . \text { Sim, menos de uma vez por mês } 2 \text {. Sim, uma ou duas vezes por mês } \\
\text { 3. Sim, uma ou duas vezes por semana } 4 \text {. Sim, três a quatro vezes por semana } \\
\text { 5. Todo ou quase todo dia (+ de } 5 \text { vezes por semana) }\end{array}$ & V.8. \\
\hline $\begin{array}{l}\text { 9. Você tem plano de saúde odontológico? } \\
\text { 0.Não } 1 . \mathrm{Sim}\end{array}$ & V.9. \\
\hline $\begin{array}{l}\text { 10. Seu(ua) filho(a) recebeu atendimento dentário no último ano? } \\
\text { 0. Năo } 1 . \mathrm{Sim}\end{array}$ & V.10. \\
\hline $\begin{array}{l}\text { 11.Se sim, onde ocorreu este atendimento? } \\
\begin{array}{lll}\text { 1. Serviço público-posto de saúde } & \text { 2. serviço público- na própria escola } \\
\text { 3. Clinica da universidade } & \text { 4. Consultório particular } & \end{array}\end{array}$ & V.11. \\
\hline 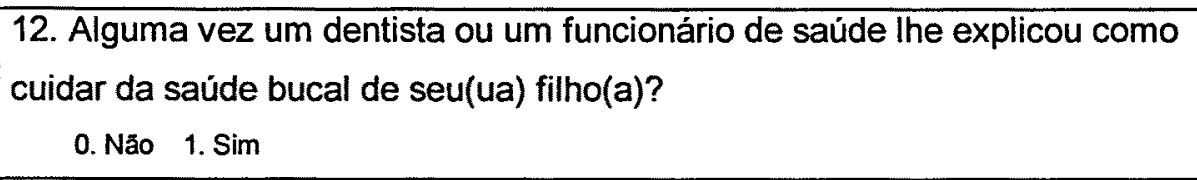 & V.12. \\
\hline
\end{tabular}




\section{ANEXO 3}

Formulário para as crianças

\begin{tabular}{|c|c|}
\hline Nome da criança: & Escola \\
\hline $\begin{array}{l}\text { 1. Atividade de prevenção na escola com bochecho semanal de Flúor } \\
\begin{array}{ll}\text { l. sim } & \text { 2. Não }\end{array}\end{array}$ & V 1. \\
\hline $\begin{array}{l}\text { 2. Atividade de prevenção na escola de escovação (supervisionada) com flúor } \\
\begin{array}{ll}\text { 1. } \operatorname{sim} & \text { 2. não }\end{array}\end{array}$ & V2. \\
\hline $\begin{array}{l}\text { 3. Atividade de prevenção na escola com aplicação semestral de gel de flúor com } \\
\text { moldeira } \\
\begin{array}{ll}1 . \operatorname{sim} & \text { 2. Não }\end{array}\end{array}$ & V 3. \\
\hline 1. $\operatorname{sim}$ 2. não & V 4. \\
\hline $\begin{array}{l}\text { 5. qual a frequência na semana? } \\
\begin{array}{lll}\text { 1. } 0-2 \text { vezes } & \text { 2. } 3-5 \text { vezes } & \text { 3. } 6 \text { ou mais vezes }\end{array}\end{array}$ & V 5. \\
\hline 6. . bebe chá preto? & V 6. \\
\hline $\begin{array}{l}\text { 7. qual a frequência na semana? } \\
\begin{array}{lll}\text { 1. } 0-2 \text { vezes } & \text { 2. } 3-5 \text { vezes } & 3.6 \text { ou mais vezes }\end{array}\end{array}$ & V 7. \\
\hline $\begin{array}{l}\text { 8. Quantas vezes você limpa os seus dentes por dia? } \\
\begin{array}{lll}\text { 1.Uma vez } & \text { 2. Duas vezes } & 3 . \text { Mais de duas vezes }\end{array}\end{array}$ & V8. \\
\hline 9. Limpa os dentes todos os dias? & V 9. \\
\hline 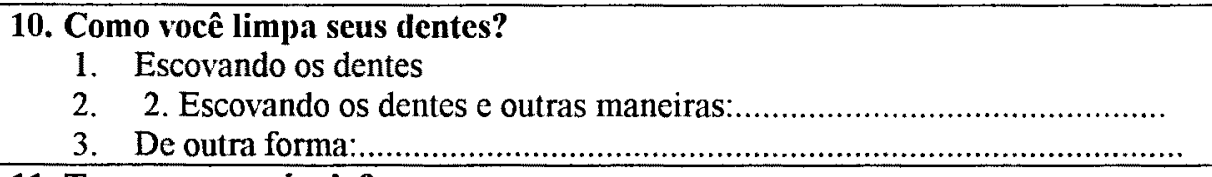 & $\mathbf{V} 10$ \\
\hline $\begin{array}{l}\text { 11. Tem escova própria? } \\
\begin{array}{ll}\text { 1. sim } & \text { 2. não }\end{array}\end{array}$ & V11. \\
\hline $\begin{array}{l}\text { 12. Usa creme dental toda vez que escova os dentes? } \\
\begin{array}{ll}\text { 1. sim } & \text { 2. Não }\end{array}\end{array}$ & V12. \\
\hline 13. Qual a marca do creme dental que você usa ou já usou com mais frequência? & V13. \\
\hline $\begin{array}{l}\text { 14.Você come doces ou alimentos açucarados (p. ex sobremesa, balas, chicletes, } \\
\text { chocolates)? } \\
\begin{array}{llll}\text { 1. Nunca } & \text { 2. Raramente } & \text { 3. Às vezes } & \text { 4. Freqüentemente/sempre }\end{array}\end{array}$ & V14. \\
\hline $\begin{array}{l}\text { 15.Quantas vezes, ontem, você comeu doces? } \\
\begin{array}{lll}\text { 1. } 0-2 \text { vezes } & \text { 2. } 3-5 \text { vezes } & 3.6 \text { ou mais vezes }\end{array}\end{array}$ & V15. \\
\hline
\end{tabular}


ANEXO 4

Ficha para o exame clínico adaptada da ficha proposta pela WHO (1997)

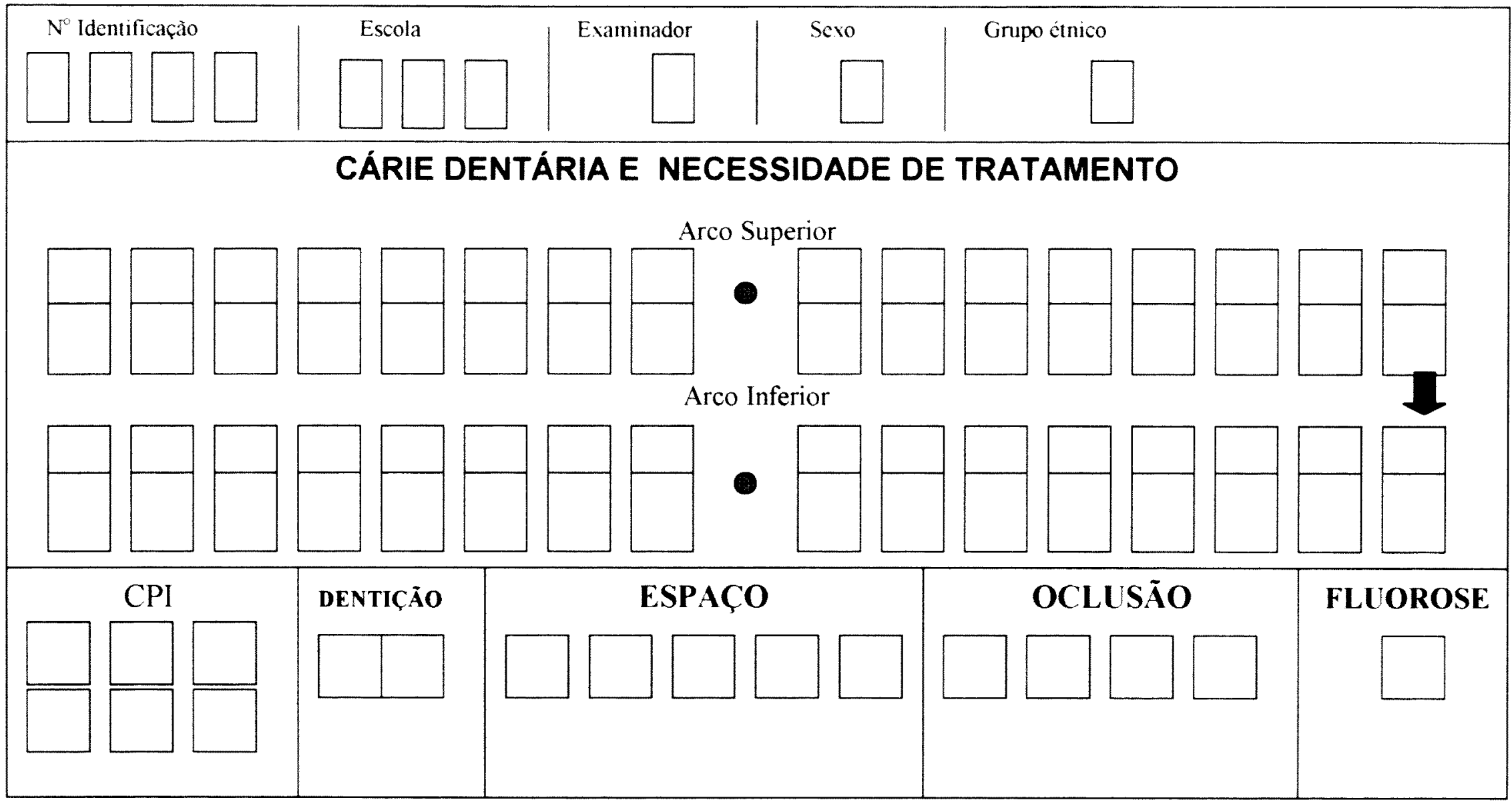




\title{
ANEXO 5 -Carta à Diretoria das escolas.
}

\author{
is \\ UNIVERSIDADE ESTADUAL DE FEIRA DE SANTANA \\ AUTORIZADA PELO DECRETO FEDERAL N O 77.496 DE 27-4-1976 \\ Reconhecida pela Portaria Ministerial n.o 874/86 de 19.12.86 \\ Feira de Santana, \\ de 2001 .
}

Para:Sr(a)

Diretor(a) da Escola

Exmo(a). Sr(a). Diretor(a),

Estamos realizando uma pesquisa científica para o curso de Doutorado em Saúde Pública da Faculdade de Saúde Pública da Universidade de São Paulo em convênio com a UEFS. O objeto de estudo deste trabalho será conhecer a Atenção em Saúde Bucal aos escolares com doze anos de idade na cidade de Feira de Santana.

Para a sua realização será preciso examinar crianças desta faixa etária em algumas escolas da cidade. Os exames serão realizados segundos os princípios de segurança e proteção ao paciente, com materiais descartáveis e esterilizados. Também será assegurado o sigilo em relação à identificação das escolas e alunos participantes da pesquisa.

A escola que V. Sa. dirige foi selecionada para ser incluída na pesquisa, assim pedimos seu consentimento e colaboração junto ao corpo docente e funcionários para a estruturação dos trabalhos.

Certa de vossa compreensão, agradeço desde já a atenção dispensada e nos colocamos à disposição para qualquer esclarecimento.

Atenciosamente, 


\title{
ANEXO 6 \\ Solicitação de autorização ao pai ou responsável
}

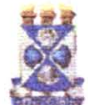 \\ UNIVERSIDADE ESTADUAL DE FEIRA DE SANTANA \\ AUTORIZADA PELO DECRETO FEDERAL N.O 77.496 DE 27-4-1976 \\ Reconhecida pela Portaria Ministerial n.o 874/86 de 19.12.86
}

Feira de Santana, de 2001 .

\section{Ao pai ou responsável por:}

Está sendo realizada uma pesquisa científica para o curso de Doutorado em Saúde Pública pela Faculdade de Saúde Pública da Universidade de São Paulo em convênio com a UEFS. Neste trabalho buscamos conhecer a Atenção em Saúde Bucal aos escolares com doze anos de idade na cidade de Feira de Santana.

Para a sua realização será preciso examinar crianças desta idade em algumas escolas da cidade. Os exames serão realizados segundos os princípios de segurança e proteção ao paciente, com materiais descartáveis e esterilizados conforme é recomendado pela Organização Mundial de Saúde e Ministério de Saúde do Brasil. Também será assegurado o sigilo em relação à identificação das escolas e alunos participantes da pesquisa, no entanto, apesar dos dados individuais não serem divulgados, os resultados da pesquisa poderão ajudar a prevenir doenças bucais e a implantar medidas preventivas.

Todas as crianças que participarão da pesquisa serão examinadas por cirurgiões-dentistas, sendo que este exame não provoca nenhuma dor, lesão ou sangramento e constará apenas da observação das características dos dentes, gengivas e arcadas da boca da criança.

A escola que seu(ua) filho(a) estuda foi selecionada para ser incluída na pesquisa e a Direção da escola já está ciente sobre a pesquisa. Assim pedimos seu consentimento e colaboração para que a sua criança possa ser examinada. Destaca-se que a participação não é obrigatória, podendo $\mathrm{V}$. Sa. se recusar a concedê-la sem que isto the traga qualquer prejuizo ou para a criança.

Certa de vossa compreensão, agradeçemos desde já a atenção dispensada e nos colocamos à disposição para qualquer esclarecimento.

Atenciosamente,

\section{Prof $^{a}$ Técia Daltro Borges Alves \\ Responsável pela pesquisa}

Autorizo (assinatura do pai/responsável e data) :

$\mathrm{N}^{\circ}$ da Carteira de Identidade: 


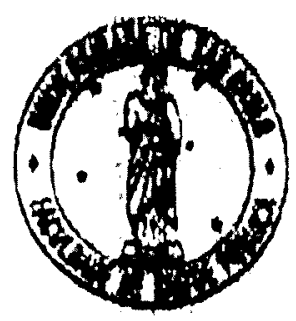

\section{UNIVERSIDADE DE SAO PAULO FACULDADE DE SAUDE PUELICA COMITE DE ETICA EM PESQUISAMCDEP \\ Av. Dr. Arauldo, 71s:- Corqueira Cobur Siat Prulu-SP - CEP: 01246-904 \\ Telefuce: $(0 \times 111)$ 3066-7779-omall: mdortcusousp.br}

Of. COEP $/ 036 / 01$

2) de março de 2001

Pelo presente, informo que o Comite de Efica em Pesquisa da Faculdade de Saúde Pública da Universidade de Sá Paulo-COEP, analisou aprovou, em sua 2\%00 Sessão Ordinária, de 20.0301 , de acordo com os requistros da Resoluçăo CNS/196/96, o Protocolo de Posquisa n."430, intirulado: "ATENTCOO EM SAĆDE BLCAL A ESCOLARES COM 12 ANOS DE TDADE DO MUNICLOIO DE FELRA DE SANTANAMAHIA - ZONA URBANA", apresentado pola pesquisadora Técia Daltro Borges Alves

Atenciosamente.

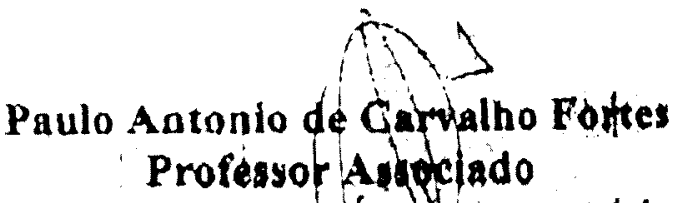

Vice-Coordenador do Comitê de tief em Petquisa da FSP-COEP 


\section{ANEXO 8}

\section{CÁLCULO DO ÍNDICE DE KAPPA CALIBRAÇÃO INICIAL}

$$
K a p p a=\frac{f o-f c}{N-f c}
$$

$\begin{array}{ll}\text { Classificação: } & \\ <0,00 & \text { concordância pobre } \\ 0,00-0,20 & \text { concordância leve } \\ 0,21-0,40 & \text { concordância fraca } \\ 0,41-0,60 & \text { concordância moderada } \\ 0,61-0,80 & \text { concordância substancial } \\ 0,81-1,00 & \text { concordância quase perfeita/ } \\ & \text { perfeita }\end{array}$

\section{Cálculo do Índice Kappa do CPOD}

\begin{tabular}{|c|cccccccccccc|c|}
\hline & $\mathbf{0}$ & $\mathbf{1}$ & $\mathbf{2}$ & $\mathbf{3}$ & $\mathbf{4}$ & $\mathbf{5}$ & $\mathbf{6}$ & $\mathbf{7}$ & $\mathbf{8}$ & $\mathbf{9}$ & $\mathbf{T}$ & Total \\
\hline $\mathbf{0}$ & 688 & 13 & - & - & - & - & - & - & - & - & - & $\mathbf{7 0 9}$ \\
$\mathbf{1}$ & 8 & 26 & - & 1 & - & - & - & - & - & - & - & 35 \\
$\mathbf{2}$ & - & 1 & 3 & - & - & - & - & - & - & - & - & 4 \\
$\mathbf{3}$ & 2 & - & 1 & 29 & - & - & - & - & - & - & - & $\mathbf{3 2}$ \\
$\mathbf{4}$ & 1 & - & - & - & - & - & - & - & - & - & - & $\mathbf{1}$ \\
$\mathbf{5}$ & - & - & - & - & - & - & - & - & - & - & - & - \\
$\mathbf{6}$ & 1 & - & - & - & - & - & 7 & - & - & - & - & $\mathbf{8}$ \\
$\mathbf{7}$ & - & - & - & - & - & - & - & - & - & - & - & - \\
$\mathbf{8}$ & 7 & - & - & - & - & - & - & - & 192 & - & - & $\mathbf{1 9 9}$ \\
$\mathbf{9}$ & - & - & - & - & - & - & - & - & - & - & - & - \\
$\mathbf{T}$ & 1 & - & - & - & - & - & - & - & - & - & 3 & 4 \\
\hline Total & $\mathbf{7 0 8}$ & $\mathbf{4 0}$ & $\mathbf{4}$ & $\mathbf{3 0}$ & - & - & $\mathbf{7}$ & - & $\mathbf{2 0 0}$ & - & $\mathbf{3}$ & $\mathbf{9 9 2}$ \\
\hline
\end{tabular}
fo $=948$
$\mathrm{fc}=548,60$
Kappa $=0,901$

\begin{tabular}{|c|cccccccccc|c|}
\hline \multicolumn{10}{|c|}{ Cálculo do İndice Kappa da Necessidade de Tratamento } \\
\hline & $\mathbf{0}$ & $\mathbf{1}$ & $\mathbf{2}$ & $\mathbf{3}$ & $\mathbf{4}$ & $\mathbf{5}$ & $\mathbf{6}$ & $\mathbf{7}$ & $\mathbf{8}$ & Total \\
\hline $\mathbf{0}$ & 919 & 9 & 2 & 1 & - & - & - & 2 & 8 & $\mathbf{9 4 1}$ \\
$\mathbf{1}$ & 8 & 24 & 2 & - & - & - & - & - & - & 34 \\
2 & - & 1 & 6 & - & - & - & - & - & - & 7 \\
3 & - & - & - & - & - & - & - & - & - & - \\
4 & - & - & - & - & - & - & - & - & - & - \\
$\mathbf{5}$ & - & - & - & - & - & - & - & - & - & - \\
$\mathbf{6}$ & - & - & - & - & - & - & - & - & - & - \\
7 & - & 1 & - & - & - & - & - & - & - & 1 \\
8 & 3 & 2 & - & - & - & - & - & - & 4 & 9 \\
\hline Total & 930 & 37 & 10 & 1 & - & - & - & 2 & 12 & 992 \\
\hline
\end{tabular}
fo $=953$
$\mathrm{fc}=883,64$
Kappa $=0,640$ 


\begin{tabular}{|c|cccccc|c|}
\hline \multicolumn{7}{|c|}{ Cálculo do Indice de Kappa para CPI } \\
\hline & 0 & 1 & 2 & X & 9 & Total \\
\hline 0 & 84 & 32 & - & - & - & 116 \\
1 & 19 & 46 & - & - & - & 65 \\
2 & - & - & 5 & - & - & 5 \\
X & - & - & - & - & - & - \\
9 & - & - & - & - & - & - \\
\hline Total & 103 & 78 & 5 & - & - & 186 \\
\hline
\end{tabular}

fo $=135 \quad$ fc $=91,63 \quad$ Kappa $=\mathbf{0 , 4 6 0}$

\begin{tabular}{|c|cccccccccccc|c|}
\hline \multicolumn{10}{|c|}{ Cálculo do Indice Kappa da Dentição } \\
\hline & 0 & $\mathbf{1}$ & $\mathbf{2}$ & $\mathbf{3}$ & $\mathbf{4}$ & $\mathbf{5}$ & $\mathbf{6}$ & $\mathbf{7}$ & $\mathbf{8}$ & $\mathbf{9}$ & T & X & Total \\
\hline $\mathbf{0}$ & 46 & - & - & - & - & - & - & - & - & - & - & - & 46 \\
$\mathbf{1}$ & - & - & - & - & - & - & - & - & - & - & - & - & - \\
2 & - & - & - & - & - & - & - & - & - & - & - & - & - \\
3 & - & - & - & - & - & - & - & - & - & - & - & - & - \\
4 & - & - & - & - & - & - & - & - & - & - & - & - & - \\
$\mathbf{5}$ & - & - & - & - & - & - & - & - & - & - & - & - & - \\
6 & - & - & - & - & - & - & - & - & - & - & - & - & - \\
7 & - & - & - & - & - & - & - & - & - & - & - & - & - \\
8 & - & - & - & - & - & - & - & - & - & - & - & - & - \\
9 & - & - & - & - & - & - & - & - & - & - & - & - & - \\
T & - & - & - & - & - & - & - & - & - & - & - & - & - \\
X & - & - & - & - & - & - & - & - & - & - & - & 16 & 16 \\
\hline Total & 46 & - & - & - & - & - & - & - & - & - & - & 16 & 62 \\
\hline
\end{tabular}

$$
\text { fo }=62 \quad \text { fc }=38,26 \quad \text { Kappa }=1,000
$$

\begin{tabular}{|c|cccc|c|}
\hline \multicolumn{7}{|c|}{ Kappa do Apinhamento } \\
\hline & 0 & $\mathbf{1}$ & $\mathbf{2}$ & $\mathrm{X}$ & Total \\
\hline $\mathbf{0}$ & 9 & 1 & - & - & 10 \\
$\mathbf{1}$ & 1 & 4 & - & - & $\mathbf{5}$ \\
$\mathbf{2}$ & 1 & 3 & 4 & - & 8 \\
$\mathbf{X}$ & - & - & - & 8 & $\mathbf{8}$ \\
\hline Total & $\mathbf{1 1}$ & $\mathbf{8}$ & $\mathbf{4}$ & $\mathbf{8}$ & $\mathbf{3 1}$ \\
\hline
\end{tabular}

$$
\text { fo }=25 \quad \text { fc }=7,94 \quad \text { Kappa }=\mathbf{0 , 7 4 0}
$$

\begin{tabular}{|c|cccc|c|}
\hline \multicolumn{7}{|c|}{ Kappa do Espaçamento } \\
\hline & 0 & 1 & 2 & X & Total \\
\hline 0 & 20 & 2 & - & - & 22 \\
1 & - & 1 & - & - & 1 \\
2 & - & - & - & - & - \\
X & - & - & - & 8 & 8 \\
\hline Total & 20 & 3 & - & 8 & 31 \\
\hline
\end{tabular}
fo $=29$
$f C=16,35$
Kappa $=0,863$ 


\begin{tabular}{|c|cccc|c|}
\hline \multicolumn{7}{|c|}{ Cálculo do indice de Kappa do Diastema } \\
\hline & 0 & 1 & 3 & X & Total \\
\hline 0 & 22 & - & - & - & 22 \\
1 & - & - & - & - & - \\
3 & - & - & 1 & - & 1 \\
X & - & - & - & 8 & 8 \\
\hline Total & 22 & - & 1 & 8 & 31 \\
\hline
\end{tabular}

fo $=31 \quad f c=17,71 \quad$ Kappa $=\mathbf{1 , 0 0 0}$

\begin{tabular}{|c|cccccc|c|}
\hline \multicolumn{1}{|c|}{ Cálculo do indice de Kappa do Desalinhamento Maxilar } \\
\hline & $\mathbf{0}$ & $\mathbf{1}$ & $\mathbf{2}$ & $\mathbf{3}$ & $\mathbf{4}$ & $\mathrm{X}$ & Total \\
\hline $\mathbf{0}$ & 13 & 1 & - & - & - & - & $\mathbf{1 4}$ \\
$\mathbf{1}$ & 1 & 1 & - & - & - & - & $\mathbf{2}$ \\
2 & - & - & 1 & - & - & - & 1 \\
$\mathbf{3}$ & - & - & - & 4 & 2 & - & 6 \\
$\mathbf{4}$ & - & - & - & - & - & - & - \\
$\mathbf{X}$ & - & - & - & - & - & 8 & $\mathbf{8}$ \\
\hline Total & $\mathbf{1 4}$ & $\mathbf{2}$ & $\mathbf{1}$ & $\mathbf{4}$ & $\mathbf{2}$ & $\mathbf{8}$ & $\mathbf{3 1}$ \\
\hline
\end{tabular}

fo $=\mathbf{2 7}$ fc $=9,32 \quad$ Kappa $=\mathbf{0 , 8 1 5}$

\begin{tabular}{|c|ccccc|c|}
\hline \multicolumn{6}{|c}{ Cálculo do índice de Kappa do Desalinhamento Mandibular } \\
\hline & 0 & $\mathbf{1}$ & $\mathbf{2}$ & $\mathbf{3}$ & $\mathrm{X}$ & Total \\
\hline $\mathbf{0}$ & 15 & 2 & 1 & 1 & - & 19 \\
1 & 3 & - & - & - & - & 3 \\
2 & - & - & - & 1 & - & 1 \\
3 & - & - & - & - & - & - \\
$\mathrm{X}$ & - & - & - & - & 8 & 8 \\
\hline Total & 18 & 2 & $\mathbf{1}$ & $\mathbf{2}$ & $\mathbf{8}$ & 31 \\
\hline
\end{tabular}

fo $=\mathbf{2 3} \quad \mathrm{fc}=13,32 \quad$ Kappa $=\mathbf{0 , 5 4 7}$

\begin{tabular}{|c|cccccccccc|c|}
\hline \multicolumn{10}{|c|}{ Kappa da Sobresaliência Maxilar } \\
\hline & $\mathbf{0}$ & $\mathbf{1}$ & $\mathbf{2}$ & $\mathbf{3}$ & $\mathbf{4}$ & $\mathbf{5}$ & $\mathbf{6}$ & $\mathbf{8}$ & $\mathbf{9}$ & $\mathbf{X}$ & Total \\
\hline $\mathbf{0}$ & 2 & - & 1 & - & - & - & - & - & - & - & $\mathbf{3}$ \\
$\mathbf{1}$ & - & - & - & - & - & - & - & - & - & - & - \\
$\mathbf{2}$ & - & - & 2 & 1 & - & - & - & - & - & - & 3 \\
$\mathbf{3}$ & - & 1 & 1 & 4 & 1 & - & - & - & - & - & 7 \\
$\mathbf{4}$ & - & - & 1 & - & - & - & - & - & - & - & 1 \\
$\mathbf{5}$ & - & - & - & 1 & 2 & 3 & - & - & - & - & $\mathbf{6}$ \\
$\mathbf{6}$ & - & - & - & - & 1 & - & 1 & - & - & - & $\mathbf{2}$ \\
$\mathbf{8}$ & - & - & - & - & - & - & - & - & 1 & - & $\mathbf{1}$ \\
$\mathbf{9}$ & - & - & - & - & - & - & - & - & - & - & - \\
$\mathbf{X}$ & - & - & - & - & - & - & - & - & - & 8 & $\mathbf{8}$ \\
\hline Total & $\mathbf{2}$ & $\mathbf{1}$ & $\mathbf{5}$ & $\mathbf{6}$ & $\mathbf{4}$ & $\mathbf{3}$ & $\mathbf{1}$ & - & $\mathbf{1}$ & $\mathbf{8}$ & $\mathbf{3 1}$ \\
\hline
\end{tabular}

fo $=20 \quad$ fc $=4,87 \quad$ Kappa $=0,579$ 


\begin{tabular}{|c|cc|c|}
\hline \multicolumn{5}{|c|}{ Kappa da Sobresaliência Mandibular } \\
\hline & 0 & $\mathbf{X}$ & Total \\
\hline 0 & 23 & - & 23 \\
$\mathrm{X}$ & - & 8 & 8 \\
\hline Total & 23 & 8 & 31 \\
\hline
\end{tabular}

$$
\text { fo }=31 \quad \text { fc }=19,13 \quad \text { Kappa }=\mathbf{1 , 0 0 0}
$$

\begin{tabular}{|c|ccc|r|}
\hline \multicolumn{6}{|c|}{ Kappa da Mordida Aberta } \\
\hline & 0 & 5 & X & \multicolumn{1}{|c|}{ Total } \\
\hline 0 & 22 & - & - & 22 \\
5 & - & 1 & - & 1 \\
X & - & - & 8 & 8 \\
\hline Total & 22 & 1 & 8 & 31 \\
\hline
\end{tabular}

$$
\text { fo }=\mathbf{3 1} \text { fc }=17,71 \quad \text { Kappa }=\mathbf{1 , 0 0 0}
$$

\begin{tabular}{|c|ccccc|r|}
\hline \multicolumn{7}{|c|}{ Kappa da Relação Molar } \\
\hline & $\mathbf{0}$ & $\mathbf{1}$ & $\mathbf{2}$ & $\mathbf{X}$ & \multicolumn{1}{|c|}{ Total } \\
\hline $\mathbf{0}$ & 2 & - & 3 & - & $\mathbf{5}$ \\
$\mathbf{1}$ & - & 3 & 4 & - & $\mathbf{7}$ \\
$\mathbf{2}$ & - & 1 & 10 & - & $\mathbf{1 1}$ \\
$\mathbf{X}$ & - & - & - & 8 & $\mathbf{8}$ \\
\hline Total & $\mathbf{2}$ & $\mathbf{4}$ & $\mathbf{1 7}$ & $\mathbf{8}$ & $\mathbf{3 1}$ \\
\hline
\end{tabular}
fo $=$
23
$\mathrm{fc}=\quad 9,32$
Kappa $=0,631$

\begin{tabular}{|c|cccccccc|c|}
\hline \multicolumn{10}{|c|}{ Cálculo do Indice Kappa da Fluorose } \\
\hline & $\mathbf{0}$ & $\mathbf{1}$ & $\mathbf{2}$ & $\mathbf{3}$ & $\mathbf{4}$ & $\mathbf{5}$ & $\mathbf{8}$ & $\mathbf{9}$ & Total \\
\hline $\mathbf{0}$ & 15 & 1 & 1 & - & - & - & - & - & 17 \\
$\mathbf{1}$ & 2 & 5 & - & - & - & - & - & - & 7 \\
2 & - & - & 5 & - & - & - & - & - & 5 \\
3 & - & - & - & 1 & - & - & - & - & 1 \\
4 & - & - & - & - & 1 & - & - & - & 1 \\
$\mathbf{5}$ & - & - & - & - & - & - & - & - & - \\
$\mathbf{8}$ & - & - & - & - & - & - & - & - & - \\
$\mathbf{9}$ & - & - & - & - & - & - & - & - & - \\
\hline Total & 17 & 6 & 6 & 1 & 1 & - & - & - & 31 \\
\hline
\end{tabular}
fo $=\quad 27$
$f c=11,71$
Kappa $=0,793$ 


\section{CÁLCULO DO ÍNDICE DE KAPPA REEXAMES}

\begin{tabular}{|c|c|c|c|c|c|c|c|c|c|c|c|c|}
\hline \multicolumn{13}{|c|}{ Cálculo do Índice Kappa do CPOD } \\
\hline & 0 & 1 & 2 & 3 & 4 & 5 & 6 & 7 & 8 & 9 & $T$ & Total \\
\hline 0 & 2.363 & 7 & - & - & - & - & 2 & - & - & - & - & 2.372 \\
\hline 1 & 4 & 123 & - & - & - & - & - & - & - & - & - & 127 \\
\hline 2 & - & - & 4 & - & - & - & - & - & - & - & - & 4 \\
\hline 3 & - & - & - & 86 & - & - & - & - & - & - & - & 86 \\
\hline 4 & - & - & - & - & 7 & - & - & - & - & - & - & 7 \\
\hline 5 & - & - & - & - & - & 2 & - & - & - & - & - & 2 \\
\hline 6 & - & - & - & - & - & - & 33 & - & - & - & - & 33 \\
\hline 7 & - & - & - & - & - & - & - & - & - & - & - & - \\
\hline 8 & - & - & - & - & - & - & - & - & 561 & - & - & 561 \\
\hline 9 & - & - & - & - & - & - & - & - & - & - & - & - \\
\hline $\mathbf{T}$ & - & - & - & - & - & - & - & - & - & - & 8 & 8 \\
\hline Total & 2.367 & 130 & & 86 & 7 & 2 & 35 & - & 561 & - & 8 & 3.200 \\
\hline
\end{tabular}

$$
\text { fo }=\mathbf{3 1 8 7} \quad \mathrm{fc}=1.860,76 \quad \text { Kappa }=\mathbf{0 , 9 9 0}
$$

\section{Cálculo do Índice de Kappa da Necessidade de Tratamento}

\begin{tabular}{|c|ccccccccc|c|}
\hline & $\mathbf{0}$ & $\mathbf{1}$ & $\mathbf{2}$ & $\mathbf{3}$ & $\mathbf{4}$ & $\mathbf{5}$ & $\mathbf{6}$ & $\mathbf{7}$ & $\mathbf{8}$ & Total \\
\hline $\mathbf{0}$ & 2.995 & 7 & - & - & - & - & - & - & 3 & $\mathbf{3 . 0 0 5}$ \\
$\mathbf{1}$ & 2 & 71 & 2 & - & - & - & - & - & - & $\mathbf{7 5}$ \\
2 & 1 & 2 & 39 & - & - & - & - & - & 1 & 43 \\
3 & - & - & - & 2 & - & - & - & - & - & 2 \\
4 & - & - & - & - & - & - & - & - & - & - \\
$\mathbf{5}$ & - & - & - & - & - & 5 & - & - & - & 5 \\
6 & - & - & - & - & - & - & 5 & - & - & 5 \\
7 & - & - & - & - & - & - & - & - & - & - \\
8 & 2 & 1 & - & - & - & - & - & - & 62 & 65 \\
\hline & & & & & & & & & 66 & 3.200 \\
\hline
\end{tabular}

$$
\text { fo }=3.179 \quad \text { fc }=2820,99 \quad \text { Kappa }=0,945
$$

\begin{tabular}{|c|cccccc|c|}
\hline \multicolumn{7}{|c|}{ Cálculo do Indice de Kappa para CPI } \\
\hline & 0 & 1 & 2 & X & 9 & Total \\
\hline 0 & 448 & 5 & 3 & - & - & 456 \\
1 & 9 & 59 & 2 & - & - & 70 \\
2 & - & - & 74 & - & - & 74 \\
X & - & - & - & - & - & - \\
9 & - & - & - & - & - & - \\
\hline Total & 457 & 64 & 79 & - & - & 600 \\
\hline
\end{tabular}
fo $=581$
$f c=364,53$
Kappa $=0,919$ 


\begin{tabular}{|c|cccccccccccc|c|}
\hline \multicolumn{110}{|c|}{ Cálculo do Índice Kappa da Dentição } \\
\hline & 0 & 1 & 2 & 3 & 4 & 5 & 6 & 7 & 8 & 9 & T & X & Total \\
\hline 0 & 146 & - & - & - & - & - & - & - & - & - & - & - & 146 \\
1 & - & - & - & - & - & - & - & - & - & - & - & - & - \\
2 & - & - & - & - & - & - & - & - & - & - & - & - & - \\
3 & - & - & - & - & - & - & - & - & - & - & - & - & - \\
4 & - & - & - & - & - & - & - & - & - & - & - & - & - \\
5 & - & - & - & - & - & - & - & - & - & - & - & - & - \\
6 & - & - & - & - & - & - & - & - & - & - & - & - & - \\
7 & - & - & - & - & - & - & - & - & - & - & - & - & - \\
8 & - & - & - & - & - & - & - & - & - & - & - & - & - \\
9 & - & - & - & - & - & - & - & - & - & - & - & - & - \\
T & - & - & - & - & - & - & - & - & - & - & - & - & - \\
X & - & - & - & - & - & - & - & - & - & - & - & 54 & 54 \\
\hline Total & 146 & - & - & - & - & - & - & - & - & - & - & 54 & 200 \\
\hline
\end{tabular}

fo $=\mathbf{2 0 0}$ fc $=121,16 \quad$ Kappa $=\mathbf{1 , 0 0 0}$

\begin{tabular}{|c|cccc|r|}
\hline \multicolumn{7}{|c|}{ Kappa do Apinhamento } \\
\hline & 0 & 1 & 2 & X & Total \\
\hline 0 & 43 & 1 & - & - & 44 \\
1 & - & 8 & 1 & - & 9 \\
2 & - & - & 20 & - & 20 \\
X & - & - & - & 27 & 27 \\
\hline Total & 43 & 9 & 21 & 27 & 100 \\
\hline
\end{tabular}
fo $=98$
$f c=31,22$
Kappa $=0,971$

\begin{tabular}{|c|cccc|r|}
\hline \multicolumn{7}{|c|}{ Kappa do Espaçamento } \\
\hline & 0 & $\mathbf{1}$ & $\mathbf{2}$ & $\mathbf{X}$ & \multicolumn{1}{|c|}{ Total } \\
\hline 0 & 51 & - & - & - & 51 \\
1 & - & 11 & - & - & 11 \\
2 & - & - & 11 & - & 11 \\
$\mathbf{X}$ & - & - & - & 27 & 27 \\
\hline Total & 51 & 11 & 11 & 27 & 100 \\
\hline
\end{tabular}
$f o=100$
$\mathrm{fC}=\quad 35,72$
Kappa $=1,000$

\begin{tabular}{|c|ccccc|r|}
\hline \multicolumn{7}{|c|}{ Cálculo do Indice de Kappa para Diastema } \\
\hline & 0 & 1 & 2 & 3 & $X$ & Total \\
\hline 0 & 62 & - & - & - & - & 62 \\
1 & - & 6 & - & - & - & 6 \\
2 & - & - & 3 & 1 & - & 4 \\
3 & - & - & - & 1 & - & 1 \\
X & - & - & - & - & 27 & 27 \\
\hline Total & 62 & 6 & 3 & 2 & 27 & 100 \\
\hline
\end{tabular}




\begin{tabular}{|c|ccccccc|r|}
\hline \multicolumn{10}{|c|}{ Cálculo do Indice Kappa do Desalinhamento Maxilar } \\
\hline & $\mathbf{0}$ & $\mathbf{1}$ & $\mathbf{2}$ & $\mathbf{3}$ & $\mathbf{4}$ & $\mathbf{5}$ & $\mathbf{X}$ & \multicolumn{1}{|c|}{ Total } \\
\hline $\mathbf{0}$ & 48 & - & - & - & - & - & - & $\mathbf{4 8}$ \\
$\mathbf{1}$ & 2 & 6 & - & 1 & - & - & - & 9 \\
$\mathbf{2}$ & - & - & 6 & - & - & - & - & $\mathbf{6}$ \\
$\mathbf{3}$ & - & - & - & 6 & - & - & - & 6 \\
$\mathbf{4}$ & - & 1 & - & - & 2 & - & - & 3 \\
$\mathbf{5}$ & - & - & - & - & - & 1 & - & 1 \\
$\mathbf{6}$ & - & - & - & - & - & - & - & - \\
$\mathbf{X}$ & - & - & - & - & - & - & 27 & 27 \\
\hline Total & $\mathbf{5 0}$ & $\mathbf{7}$ & $\mathbf{6}$ & $\mathbf{7}$ & $\mathbf{2}$ & $\mathbf{1}$ & $\mathbf{2 7}$ & 100 \\
\hline
\end{tabular}
fo $=96$
$f c=32,77$
Kappa $=0,941$

\begin{tabular}{|c|cccccc|c|}
\hline \multicolumn{8}{|c|}{ Cálculo do Indice de Kappa do Desalinhamento Mandibular } \\
\hline & 0 & 1 & 2 & 3 & 4 & X & Total \\
\hline 0 & 56 & 1 & - & - & - & - & 57 \\
0,5 & - & - & - & - & - & - & - \\
1 & 1 & 5 & 1 & - & - & - & 7 \\
1,5 & - & - & - & - & - & - & - \\
2 & - & - & - & - & - & - & 7 \\
3 & - & - & - & 1 & - & - & 1 \\
4 & - & - & - & - & 1 & - & 1 \\
$X$ & - & - & - & - & - & 27 & 27 \\
\hline Total & 57 & 6 & 8 & 1 & 1 & 27 & 100 \\
\hline
\end{tabular}
fo $=\quad 97$
$f c=40,78 \quad$ Kappa $=\quad \mathbf{0 , 9 4 9}$

\begin{tabular}{|c|ccccccccc|c|}
\hline \multicolumn{10}{|c|}{ Cálculo do Indice de Kappa da Sobressaliência Maxilar } \\
\hline & 0 & 1 & 2 & 3 & 4 & 5 & 6 & 8 & X & Total \\
\hline 0 & 6 & - & - & - & - & - & - & - & - & 6 \\
$\mathbf{0 , 5}$ & - & - & - & - & - & - & - & - & - & - \\
$\mathbf{1}$ & 1 & 7 & - & - & - & - & - & - & - & 8 \\
2 & - & - & 7 & - & - & - & - & - & - & 7 \\
3 & - & - & 1 & 21 & 2 & - & - & - & - & 24 \\
$\mathbf{4}$ & - & - & - & 1 & 14 & - & - & - & - & 15 \\
$\mathbf{5}$ & - & - & - & - & - & 7 & - & - & - & 7 \\
$\mathbf{5 , 5}$ & - & - & - & - & - & - & - & - & - & - \\
$\mathbf{6}$ & - & - & - & - & - & - & 5 & - & - & 5 \\
8 & - & - & - & - & - & - & - & 1 & - & 1 \\
$\mathbf{8 , 5}$ & - & - & - & - & - & - & - & - & - & - \\
$\mathbf{9}$ & - & - & - & - & - & - & - & - & - & - \\
$\mathbf{X}$ & - & - & - & - & - & - & - & - & 27 & 27 \\
\hline Total & 7 & 7 & $\mathbf{7}$ & 22 & $\mathbf{1 6}$ & 7 & 5 & 1 & 27 & 100 \\
\hline
\end{tabular}

$$
\text { fo }=95 \quad \mathrm{fc}=17,26 \quad \text { Kappa }=\mathbf{0 , 9 4 0}
$$




\begin{tabular}{|c|ccc|c|}
\hline \multicolumn{5}{|c|}{ Kappa da Sobressaliência Mandibular } \\
\hline & 0 & 1 & $X$ & Total \\
\hline 0 & 71 & - & - & 71 \\
0,5 & - & - & - & - \\
1 & - & 2 & - & 2 \\
X & - & - & 27 & 27 \\
\hline Total & 71 & 2 & 27 & 100 \\
\hline
\end{tabular}
fo $=100$
$\mathrm{fc}=\quad 57,74$
Kappa $=1,000$

\begin{tabular}{|c|cccccccc|c|}
\hline \multicolumn{10}{|c|}{ Kappa da Mordida Aberta } \\
\hline & $\mathbf{0}$ & $\mathbf{1}$ & $\mathbf{2}$ & $\mathbf{3}$ & $\mathbf{4}$ & $\mathbf{6}$ & $\mathbf{8}$ & $\mathbf{X}$ & Total \\
\hline $\mathbf{0}$ & 60 & - & - & - & - & - & - & - & 60 \\
$\mathbf{1}$ & - & 3 & - & - & - & - & - & - & 3 \\
2 & - & 1 & 4 & - & - & - & - & - & 5 \\
3 & - & - & - & 2 & - & - & - & - & 2 \\
4 & - & - & - & - & 1 & - & - & - & 1 \\
6 & - & - & - & - & - & 1 & - & - & 1 \\
8 & - & - & - & - & - & - & 1 & - & 1 \\
$\mathbf{X}$ & - & - & - & - & - & - & - & 27 & 27 \\
\hline Total & 60 & 4 & 4 & 2 & 1 & 1 & 1 & 27 & 100 \\
\hline
\end{tabular}
fo $=99$
$f c=\quad 43,68$
Kappa $=0,982$

\begin{tabular}{|c|cccc|c|}
\hline \multicolumn{7}{|c|}{ Kappa da Relação Molar } \\
\hline & $\mathbf{0}$ & $\mathbf{1}$ & $\mathbf{2}$ & $\mathbf{X}$ & Total \\
\hline $\mathbf{0}$ & 25 & 2 & - & - & 27 \\
$\mathbf{1}$ & 1 & 22 & 1 & - & $\mathbf{2 4}$ \\
$\mathbf{2}$ & - & 1 & 21 & - & 22 \\
$\mathbf{X}$ & - & - & - & 27 & 27 \\
\hline Total & 26 & 25 & 22 & 27 & 100 \\
\hline
\end{tabular}

fo $=95$

$\mathrm{fc}=25,15$

Kappa $=\quad 0,933$

\begin{tabular}{|c|c|c|c|c|c|c|c|c|c|}
\hline \multicolumn{10}{|c|}{ Cálculo do Índice Kappa da Fluorose } \\
\hline & 0 & 1 & 2 & 3 & 4 & 5 & 8 & 9 & Total \\
\hline 0 & 55 & 1 & 2 & - & - & - & - & - & 58 \\
\hline 1 & 2 & 6 & 1 & - & - & - & - & - & 9 \\
\hline 2 & 2 & - & 13 & 1 & - & - & - & - & 16 \\
\hline 3 & - & 1 & - & 8 & - & - & - & - & 9 \\
\hline 4 & - & - & - & - & 3 & - & - & - & 3 \\
\hline 5 & - & - & - & - & - & 5 & - & - & 5 \\
\hline 8 & - & - & - & - & - & - & - & - & - \\
\hline 9 & - & - & - & - & - & - & - & - & - \\
\hline Total & 59 & 8 & 16 & 9 & 3 & 5 & - & - & 100 \\
\hline
\end{tabular}
fo $=90$
$f c=38,65$
Kappa $=0,837$ 